\title{
Jacopo Strada as an Imperial Architect: Background
}

\subsection{Introduction: The Austrian Habsburgs as Patrons of Architecture}

As we have seen, Emperor Ferdinand I took Jacopo Strada into his service in the spring of 1558 , but only early in 1560 Strada received a permanent appointment as 'ainem paumaister, bey unnsern gebewen alhier, that is an architect for the projects Ferdinand undertook in Vienna. He received his salary as such without interruption (though often with great delays) until he asked Rudolf II to be discharged from his court functions in 1579. ${ }^{1}$ The mere fact of this salary, which was double the amount he received as an antiquary, is sufficient reason to assume that he was expected to contribute regularly to the architectural projects of Ferdinand I and Maximilian II. Before attempting a sketch of the extent and character of Strada's contribution to these it is necessary, first to inquire into the needs and wishes of his patrons; secondly, to find out how the Imperial building activities were organized and what expertise was locally available; and thirdly, to define Strada's exact qualifications in the field.

Imperial patronage of architecture was wide-ranging: the more important part of it was utilitarian and chiefly of a military character, as is borne out by the fact that the various Imperial architects, including Strada, were paid by the Hofkriegszahlamt, the war office, rather than by the Hofkammer, which was responsible for the remuneration of most other court officials. Most of these architects, master-masons and other technicians were employed predominantly or even exclusively in Hungary, constructing fortifications against the Turks. This applies also to several of the architects we know to have been employed at court itself, either in Prague or in Vienna.

But fortification, though of paramount importance, was not the only type of architecture commissioned by Ferdinand I. After its heroic resistance to the Turkish siege of 1529, Ferdinand had moved his court to Vienna in 1533. Apart from protecting his hereditary dominions from the permanent menace of the Turks, he had to adapt Vienna to its new status as Imperial residence. Moreover he had to provide for his sons who, when grown up, needed their own

1 This chapter is partly based on a paper read at the conference Rudolf II, Prague and the World, Prague 1997, and published in its acts (Jansen 1998). On Strada's formal appointment and emoluments, Jansen $1988<\mathrm{c}>$; Jansen 1992. 
suitable establishments. By the time Strada arrived in Vienna, for this purpose Ferdinand could dispose of an existing architectural infrastructure of builders, master-masons, and architects - many of whom traditionally came from Northern Italy - whose practical building expertise doubtless was sufficient for most of the tasks he posed them. ${ }^{2}$ But few-if any—of these had much knowledge of the theoretical background of the new, classical manner of architecture that had originated in Florence and Rome, and from the mid-1530s onward was rapidly gaining firm footing outside Italy. This dearth of theoretically trained designers as opposed to practically experienced master-builders was probably quite consciously felt at court: the members of the dynasty themselves had received thorough humanist educations, and had first-hand experience of High Renaissance architecture from their visits to Mantua, Milan and Genoa. That Ferdinand I himself was not uninterested in architecture is shown by the pleasure pavilion he had constructed for his wife in the precincts of the Hradčany at Prague [Fig. 5.17]. Designed in 1538 by a Milanese architect, Paolo della Stella, this elegant trifle is generally considered to mark the introduction of the Renaissance in Bohemia.

Both the Emperor, who owned an important collection of ancient coins, and his two elder sons were interested in antiquarian studies, a discipline that was one of the principal sources for the innovations introduced into architecture in the Renaissance. They shared this interest with their counselor Hermes Schallautzer, who as Bausuperintendent was responsible for the actual organisation and administrative supervision of the various Imperial commissions in Austria. ${ }^{3}$ Both Ferdinand's sons were actively interested in architecture and engineering: when Maximilian acted as viceroy of Spain he had busied himself with plans to restructure his residence, Valladolid; Archduke Ferdinand had himself designed his extraordinary star-shaped hunting lodge at Prague. When after his father's death the Archduke moved to Innsbruck he would be the patron of the adaptation of Ambras castle [Fig. 5.1] and the addition of various galleries and a large reception hall, the 'Spanische Saal' [Fig. 5.2], which

2 Information on the architectural establishment in Vienna has been brought together by Harry Kühnel in his series 'Forschungsergebnisse zur Geschichte der Wiener Hofburg im 16. Jahrhundert' published in Anzeiger der Österreichischen Akademie der Wissenschaften: Kühnel 1956, 1958, 1959, 1961. Further information in Lietzmann 1987, pp. 105 ff.; Podewils 1991, pp. 156-177 and passim.; Rudolf 1995, pp. 175-179, 218-226 and 228 ff. Of utmost importance are the results of the huge project of the Austrian Academy of Sciences dedicated to the history of architecture, decoration and function of the Vienna Hofburg, presented in the series Veröffentlichungen zur Bau- und Funktionsgeschichte der Wiener Hofburg, those for the period 1521-1705 in the second volume, edited by Herbert Karner (Karner 2014).

3 Von Busch 1973, pp. 19-21. 

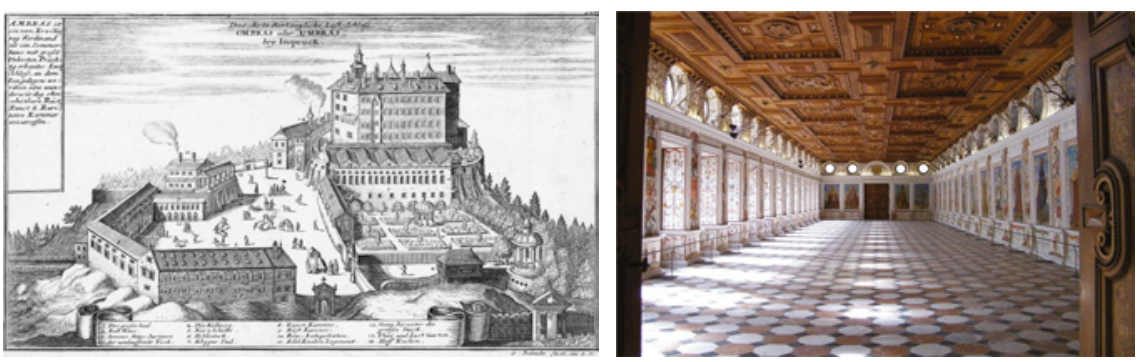

FIGURE 5.1 Ambras Castle, Innsbruck; engraving by Matthäus Merian, ca 1640.

FIGURE 5.2 Ambras Castle, reception hall ('Spanische Saal').

made it suitable both as a receptacle for his huge collections and as a residence of his morganatic consort, Philippine Welser. ${ }^{4}$

The interest in architecture of Ferdinand I and his sons of course was by no means exceptional among the princes of sixteenth-century Europe: any patronage could easily be explained merely by the need for representation. It was imperative that Ferdinand at least to some extent gave visual expression to his status as highest-ranking prince of Europe, 'il primo signore del mondo', as Strada had it. This need would almost automatically give rise to attempts of emulation with rival princes, both within the Empire and elsewhere, in particular his brother, Emperor Charles v; his brother-in-law, the French king Francis I; and his nephew, King Philip II of Spain.

Given that fact, it is remarkable that the architectural patronage of the Austrian Habsburgs from Ferdinand I up to and including Rudolf II was actually rather modest, and bears little comparison with that of these royal rivals: one thinks of the commissions of French kings (the Louvre, the Château de Madrid in the Bois de Boulogne, Chambord and Fontainebleau), of Charles V (the Palace at Granada), of Philip II of Spain (the construction of a new major city and residence at Madrid, and of the palaces of Aranjuez and El Escorial), or even of Henry viII of England (Whitehall and Nonesuch). It even seems modest compared with that of many territorial princes of Italy and the Empire: think of the Palazzo del Te and the immense ducal Palace at Mantua, the residences of the Elector August of Saxony at Dresden and Duke Albrecht V of Bavaria at Munich, and Duke Wilhelm v of Jülich-Cleves-Berg's newly built

4 Maximilian's project for the canalisation of the Pisuerga at Valladolid is referred to in Ana Díaz Medina, 'El gobierno en España de Maximiliano II (1548-1551)', in Edelmayer / Kohler, Kaiser Maximilian II., 1992, 38-54, esp. 50; on Archduke Ferdinand's hunting lodge at Prague, see now Dobalová/Hausenblasová/Muchka 2014; Simons 1998, Simons 2005 and Simons 2009, pp. 99-130. 
Renaissance palace at Jülich. And even next to the Emperor's own residence on the Hradčany in Prague, the palace built by the Bohemian magnate, Vilém z Rožmberka, could stand comparison with that of his sovereign.

This relative modesty of the architectural patronage of the Austrian branch of the Habsburgs can to a considerable extent be explained by practical factors. The most important one is certainly the lack of funds: the Emperor was almost singly responsible for the protection of Central Europe against the threat of the Turks, who actually held the larger part of one of his three kingdoms. Moreover, in none of his territories - not even the Austrian Erblandehe exercised a similarly absolute authority as his colleagues on the thrones of France and of Spain. The Estates of the Empire were seldom ready to grant the necessary subventions, and financial assistance from Spain often was too little and came too late. Such grants often came with strings attached, and were given on unpalatable and sometimes mutually contradictory conditions. ${ }^{5}$ Priority in spending the sparse funds rendered available naturally lay with the construction of fortifications against the Turks, chiefly in Hungary, the absolute necessity of which was underlined by the 1529 siege of Vienna by Suleiman the Magnificent.

Another factor is that, in contrast to foreign monarchs, the territories ruled over by Ferdinand I and his successors had as yet no natural central capital such as Paris or London. The kingdoms of Bohemia and Hungary had for centuries been ruled from Prague and Buda respectively. The Austrian Erblande each had their own central town which was usually the residence of its ruler: Innsbruck in Tyrol, Graz in Styria, Linz in Upper Austria and Vienna in Lower Austria. Even after Vienna was chosen as the residence of the Imperial court and Pressburg / Bratislava had become the centre of Habsburg Hungary after Buda had fallen to the Turks, Innsbruck kept its prominence for Ferdinand I, as his consort, Queen Anna of Hungary, usually lived there with her young children. Because of its favourable location on the principal route between Italy and Germany, Innsbruck remained important also for reasons of policy and representation. ${ }^{6}$ This means that the meagre funds available had to be divided among three major residences - at Prague, Vienna and Pressburg — and a number of minor residences that occasionally hosted the Imperial court and later would be for

5 On Maximilian II's limited financial resources, see Lanzinner 2003, p. 385. His religious concessions to the Austrian (1568, confirmed 1571) and the Bohemian Estates (1575), though perhaps not extended against his private convictions, were nevertheless largely motivated by the need of grants of revenue. At the same time such concessions further poisoned his relationship with his cousin Philip II.

6 Ferdinand I resided at Innsbruck during the final sessions of the Council of Trent in order to increase his influence on its outcome. 
some decades the principal residences of the junior branches of the dynasty. Partly for practical, partly probably also for ideological reasons, the Habsburgs adopted the traditional royal residences of each of these cities-medieval castles often only marginally adapted to contemporary demands - as their own residence and centre of their household. Funds to completely replace these by more up to date constructions lacking, it is only natural that Imperial architectural patronage in the sixteenth century remained limited to refurbishments, small additions, adaptations and redecorations. With one notable exception, Emperor Maximilian II's Neugebäude near Vienna, the Habsburg country houses, summer residences and hunting lodges were likewise quite modest in size and pretension.

\subsection{The Prince as Architect: Ferdinand I and Maximilian II as Amateurs and Patrons of Architecture}

\subsubsection{Emperor Ferdinand I}

The modesty of residential architectural patronage of the Austrian Habsburgs cannot, however, be explained by any lack of interest in the subject. When early in $155^{8}$ Strada applied to Ferdinand I to be accepted among his 'virtuosi', it seems he represented himself as an antiquarian rather than an architect, so it could be assumed that Ferdinand felt a need for Strada's competence as an antiquary. But we cannot be really sure about this: in his meeting with the King Strada would not have concealed his talents in the field of architecture, and when in 1560 Strada was formally accorded a fixed and salaried position, it was as an architect assigned to Ferdinand's building projects in Vienna, rather than as Imperial antiquary, even though he was allowed to use that title.

Of course, a connection existed between antiquarian studies and Italian High-Renaissance art and architecture: think of names such as Raphael, Giulio Romano, Serlio, Pirro Ligorio and Palladio. Though it is unlikely that this connection was generally perceived in Vienna and Prague in the 1550s, there are sufficient indications that Ferdinand himself and a small circle around him was aware of it. It is certain that Ferdinand was interested in the Antique and himself commissioned works of art inspired by the antique example from an early age: instances have been conveniently summarised in Friedrich Polleross' article 'Romanitas in der Habsburgischen Repräsentation von Karl v. bis Maximilian II.' of 2006. Symbolic of this interest is the fact that Ferdinand was portrayed in the guise of a Roman Imperator when he was hardly twenty, in a limestone bust dating from ca 1524, which was later incorporated in an entrance portal of the castle of Staré Hrady near Libán in Bohemia 

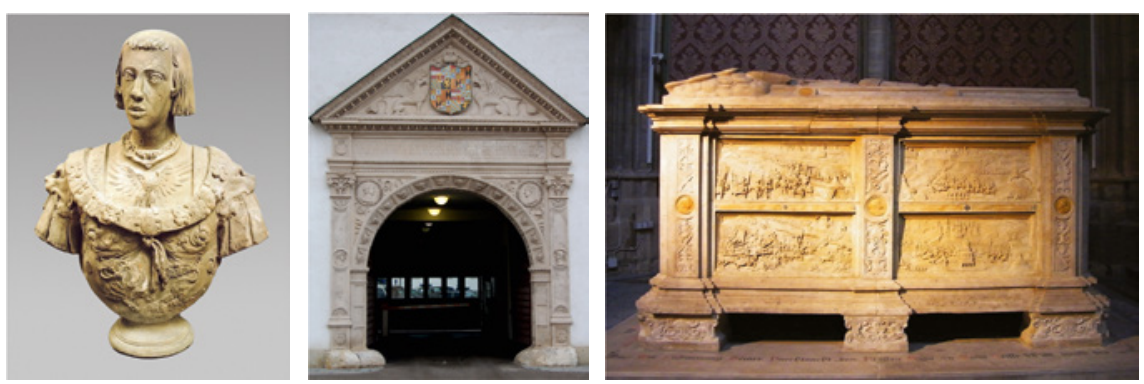

FIGURE 5.3 Anonymous sculptor, Ferdinand I as Roman Emperor, ca 1520-1525. FIGURE 5.4 The portal of the Zeughaus or Arsenal in Wiener Neustadt, dated $15^{24}$. FIGURE 5.5 Loy Hering, tomb of Count Niklas Salm, after 1530; Vienna, Votivkirche.

[Fig. 5.3]. Early examples of the use of the antique manner in commissions of Ferdinand I are the portal of the Zeughaus or arsenal in Wiener Neustadt, which is dated 1524 [Fig. 5.4], and the tomb of Count Nicholas Salm, the defender of Vienna against the Turks in 1529, which Ferdinand commissioned from Loy Hering shortly after count Salm's death in 1530 [Fig. 5.5]. ${ }^{7}$

Ferdinand was not the only patron in the Habsburg lands indulging a taste for a style of architecture based on Antique example. The new approach was pioneered also by a few highly educated, wealthy officials who were all close collaborators of the ruler, and who all, because of their origin, their studies, or both, had a more cosmopolitan outlook than their contemporaries. By far the most significant of these is Ferdinand's Chancellor Bernardo Cles, PrinceBishop of Trent, who in 1528 added a new residential block to his residence, the Castello del Buonconsiglio at Trent. He had this 'Magno Palazzo' built and decorated in the new manner introduced by Giulio Romano at the Palazzo del Te by a team of masons and craftsmen recruited in Mantua, and the painters Girolamo Romanino, Dosso and Battista Dossi, and Marcello Fogolino [Figs. 5.6-5.9]. The role of this spectacular complex in inspiring Duke Ludwig X of Bavaria to construct part of his Stadtresidenz in Landshut in the Italian manner has already been referred to, and its influence on residential architecture North of the Alps has been considerable. ${ }^{8}$

7 Polleross 2006. See also Kaiser Ferdinand I. 2003; pp. 375-376, Cat. No. IV. and p. 530, Cat. No. X.12; Holzschuh-Hofer 2014(b).

8 Cf. above, Ch. 2.3; Cles' reference to the Viena Hofburg discussed in Gabrielli 2004, pp. 19-20, and 390-391, doc. 29; and Dellantonio 2002. Bernardo Cles (Clesio, Bernhard von Cles) has been studied exhaustively both as a politician and a patron, as has the Magno Palazzo: see 

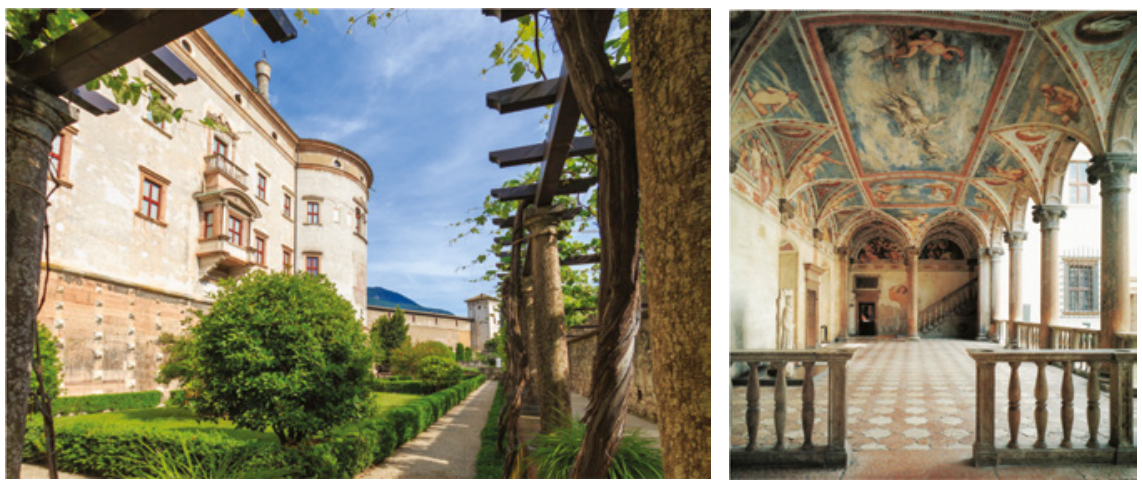

FIgURES 5.6-5.7 The Magno Palazzo built 1528-1536 for Bernardo Cles, Prince-Bishop of Trent: west facade and loggia frescoed by Girolamo Romanino, 1531-1532. Trento, Castello del Buonconsiglio.
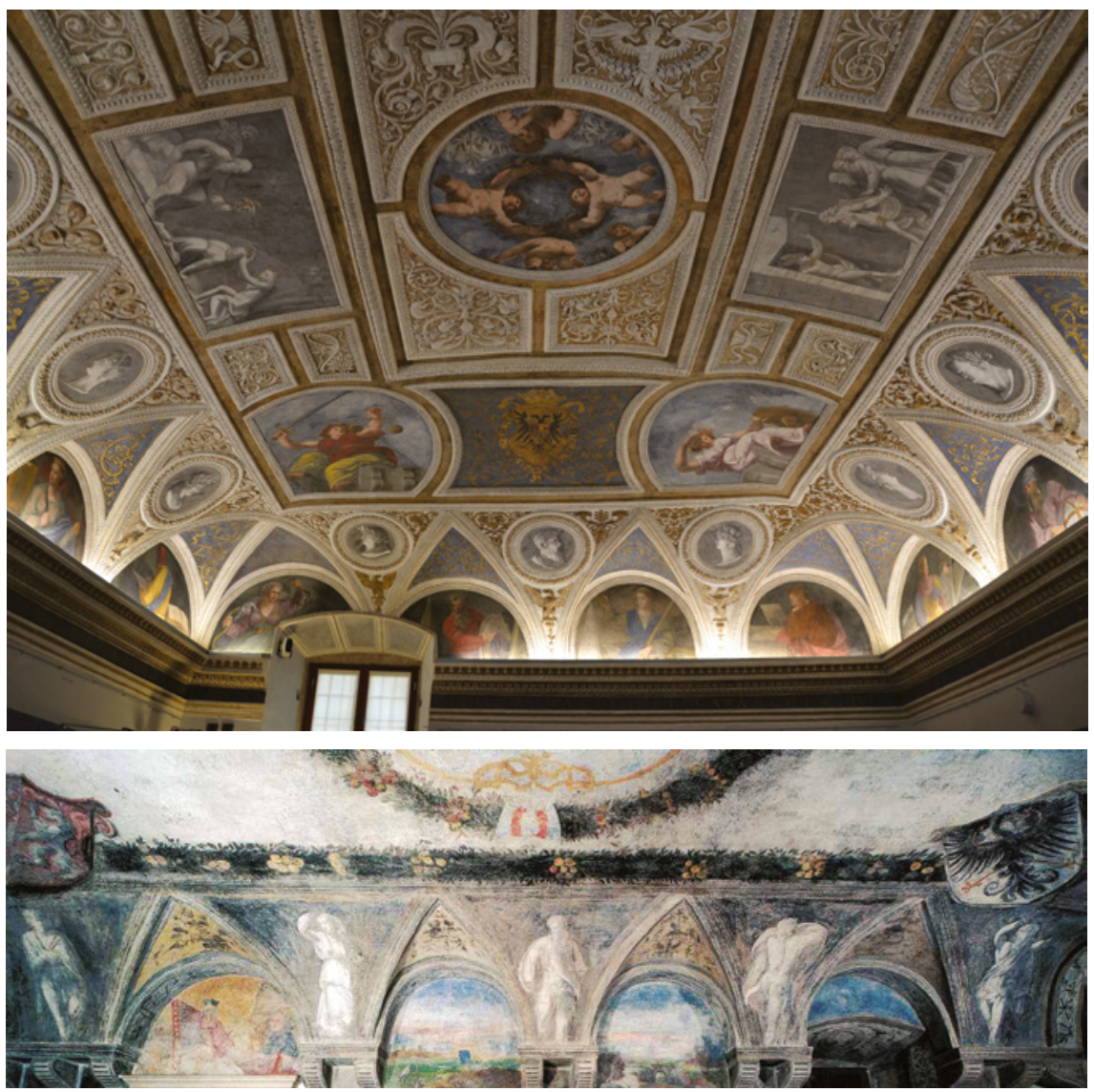

FIGURES 5.8-5.9 The Magno Palazzo: ceilings of the Camera del Camin Nero and the Stua della Famea, with frescoes on antiquarian themes by Dosso and Battista Dossi, 1531-1532; Trento, Castello del Buonconsiglio. 
In the case of Ferdinand it was reciprocal, since Cles apparently had found some inspiration in the organisation of the reconstruction of the Vienna Hofburg and its defences. Cles was in contact with Bartholomäus Amantius, with Petrus Apianus the editor of the Inscriptiones sacrosanctae vetustatis, the first printed collection of ancient epigraphy - we have met them before in Raymund Fugger's house. ${ }^{9}$ That may be the reason why he had his library decorated with images imitating Roman Imperial coins, and his dining-hall with images of ancient sculpture, pointedly painted as antiquities in an unrestored state [Figs. 5.8-5.9]: a learned and sophisticated conceit that shows that he was well aware of contemporary antiquarian discourse in Rome. This is a point explicitly made in the grand description in four hundred and forty-five stanzas in ottava rima by Pietro Andrea Mattioli to which the building owns its name: Il Magno Palazzo del Cardinale di Trento:

Quivi 'I saggio pittor quel c'ha trovato Here the learned painter has wished to show D'antichi esempi ha voluto mostrare those antique examples he had found E'l bel lavoro imperfetto ha lasciato and left these beautiful works in imperfect state Perche l'antico ha voluto imitare. because he aimed to imitate the antique. ${ }^{10}$

Ferdinand knew this complex in detail: Mattioli's poem was written on the occasion of and describes the festive visit of Ferdinand and Anna paid to Trento in September 1536, just when the complex was basically finished. ${ }^{11}$

Cles' splendid example at Trento was contagious: one of his colleagues in Ferdinand's council, Gabriel Salamanca-Ortenburg, the king's Spanish treasurer, built a splendid Renaissance castle at Spittal an der Drau in Carinthia from 1533 onwards [below, Ch. 6.5, Figs. 6.27-6.28]. But the most interesting

Chini 1985; Chini/Gramatica 1985/1988; Gorfer 1990, pp. 29-213; Castelnuovo 1995-1996; Dellantonio 2002; Gabrielli 2004; I am very grateful to Giovanni Dellantonio to have made these books available to me.

9 Cf. above, Ch. 3.3, and Figs. 3.14-3.17.

10 Venezia (Francesco Marcolini) 1539; splendid, abundantly annotated and illustrated edition by Michelangelo Lupo, in Castelnuovo 1995-1996, I, pp. 66-231 and a commentary by Massimiliano Rossi in the same volume, pp. 232-245. Stanzas $245^{-259}$ describe de Sala del Camino nero (library), 251-254 the Emperor's medals, 'tratti dal natural veri e non finti'; stanzas $263^{-265}$ describe the 'statue antiche' painted on the vault of the Stua della Famea, the dining hall.

11 Ferdinand and Anna's entry visit commemorated in stanzas 99-124, 205-214; the fireworks that concluded the festivities in stanzas $430-439$. 

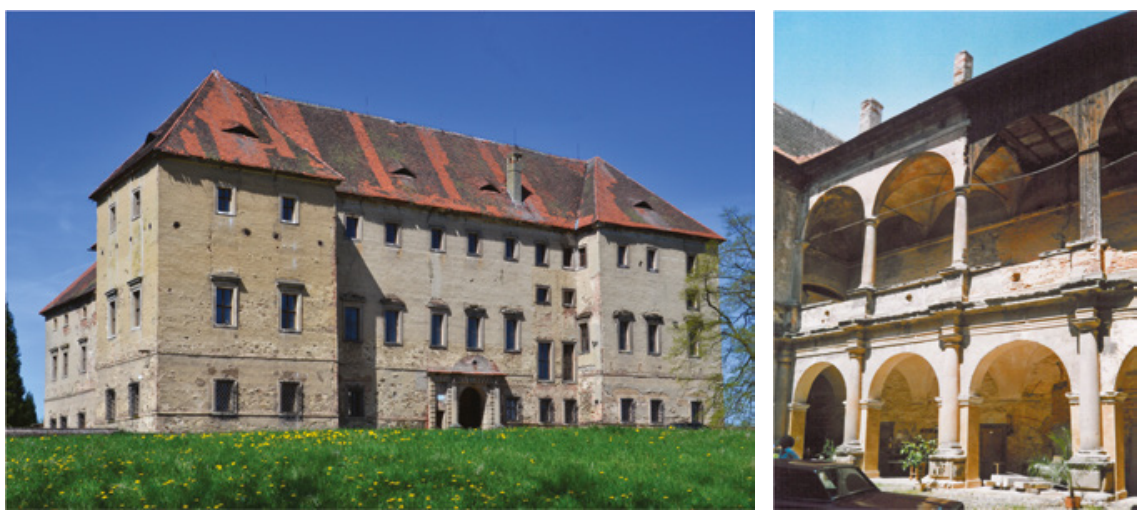

FIGURES 5.10-5.11 Paolo della Stella? or Bonifaz Wolmut? the castle at Kaceřov, Bohemia; built 1540-156o for Florian Griespek von Griespach, façade and arcade of the courtyard.

example in Bohemia was Florian Griespek von Griespach, secretary of the Bohemian Kammer, the financial authority of that kingdom, who had built two large country houses in the new manner: the very precocious Kaceřov, begun around 1540 [Figs. 5.10-5.11], and Nelahozeves, from 1553 onward; later he was to commission Bonifaz Wolmut's extraordinary church at Kralovice [below, Ch. 5.4, Fig. 5.85]. ${ }^{12}$

By the latter date Ferdinand's two eldest sons, Archdukes Maximilian and Ferdinand, became active as patrons and showed their preference for the new manner in the two hunting lodges they commissioned at Vienna and Prague, respectively, the so-called Grünes Lusthaus in the Prater near Vienna, and the star-shaped hunting-lodge Hvězda on the White Mountain near Prague [below, Ch. 5.2 and 5.3].

Apart from fortification, the architectural patronage of Ferdinand I himself was primarily directed towards the completion of some of his grandfather's projects: chief among these was the splendid tomb for Maximilian I now in the Innsbruck Hofkirche. This church was built for this specific purpose in a lateGothic manner, but with a portal in the classicizing style of the North-Italian early Renaissance [Fig. 5.12-51.3]. Beyond that, his commissions were mostly practical adaptations and extensions of his residences, chiefly the Castle at Prague and the Vienna Hofburg. But even here Ferdinand's taste for a classical style can sometimes be discerned. As early as 1536 Ferdinand employed at 12 Hubala 1985; Griessenbeck 2014, pp. 92-98 (Kaceřov), 115-118 (Kralovice), 121-127
(Nelahozeves). 

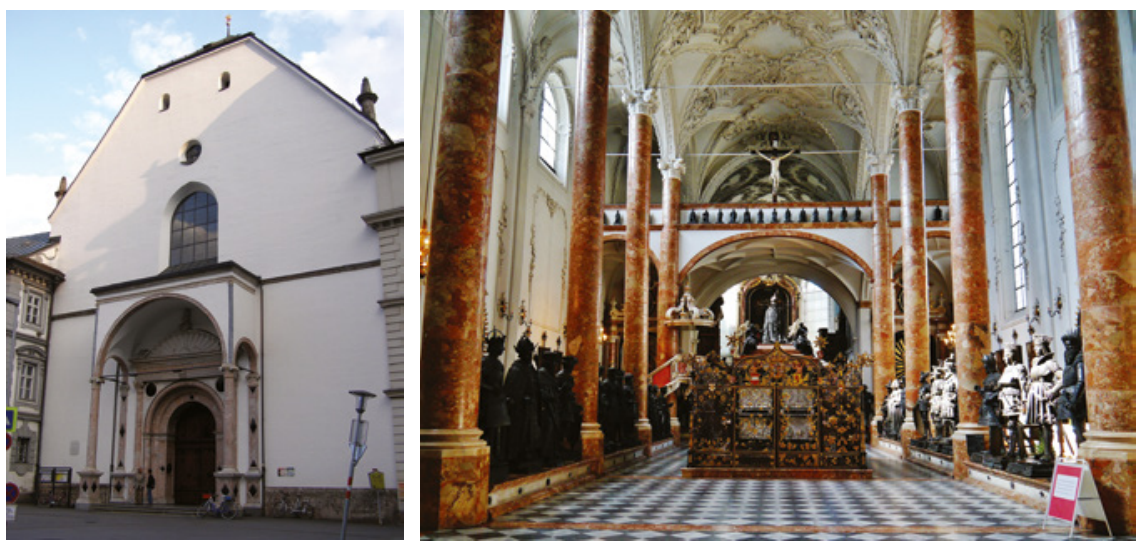

FIGURES 5.12-5.13 Innsbruck, Hofkirche, built 1553 after designs by Andrea Crivelli to house the tomb of Emperor Maximilian I: entrance portal and interior with cenotaph and bronze sculptures of the Emperor's ancestors and predecessors.

least one sculptor who could handle the ornamental elements of the new manner, witness the beautiful plaque of the Imperial arms carried by two griffins topped by an inscription dated 1536 , which commemorates his earliest interventions in the fabric of the Hofburg [Fig. 5.14]. ${ }^{13}$

The only commissions that transcend the immediately necessary and presuppose some personal motivation are the Summer Palace built for his wife, Queen Anne, the tomb for his wife and himself in St Vitus Cathedral, both in Prague, and the Vienna Hofspital. And of these it is only the Summer Palace that allows some conclusion as to his personal taste: it was built by Italians and in an Italian style, apparently from, or inspired by designs or a wooden model from Genoa brought back by the architect, the Milanese Paolo della Stella, who travelled to Genoa, in person in 1538 [Figs. 5.17] ${ }^{14}$ For that reason it is tempting to connect the Summer Palace with the seaside villa surrounded by arcades carrying open walkways that Perino del Vaga had just built for Andrea Doria at Fassolo, just outside the city walls of Genoa, which may have been known to

13 The plaque was placed above a publicly accessible fountain located in the wall separating the garden of the Hofburg from the Burggasse; the dedication to Ferdinand as 'PrInCIPE Nostro Gloriossisimo' suggest that it was financed by the city council, in recognition for the new facility; cf. Perger / Thomas 1998, p. 437; Holzschuh-Hofer 2014(b), pp. 206-208.

$14 J d K S$ x, 1889, II, pp. LXXVII-LXXVIII, Regest 6ooo, 1 June 1538; cf. Simons 2009, pp. 88-89 p. 229, n. $261-263$. 

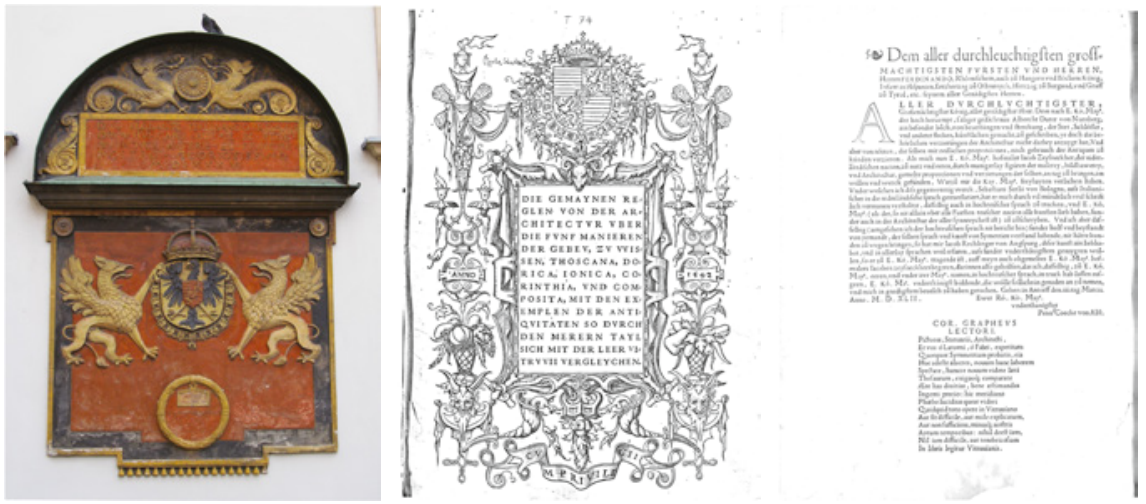

FIGURE 5.14

Plaque commemorating the earliest adaptations of the Hofburg under Ferdinand I, 1535 .

FIGURES 5.15-5.16 The German edition of Sebastiano Serlio's Fourth Book: Die gemaynen Reglen von der Architectur, Antwerp 1542: titlepage and dedication to King Ferdinand I.

Ferdinand, at least by reputation, as the prestigious project of the city's virtual ruler and one of Charles v's allies [Fig. 5.18].15

The choice to import a style that was new and exciting, but as yet foreign to the general culture of his dominions, was a conscious choice. It is difficult to say whether Ferdinand and Anna's personal taste and interests alone determined this choice, or whether reasons of policy and representation also played some role. Renate Holzschuh-Hofer has demonstrated the importance of imperial and dynastic concerns in the application of the new style and the use of symbolic elements in the figurative decoration of Ferdinand's residences. Apart from the design of the main entrance of the Hofburg, the Schweizertor [below, Figs 5.81-05.82], the most evident of these is the application of identical decorative panels, all including the fire steel-and-flint motif of the Order of the Golden Fleece, in the window surrounds of the Prague Summer Palace,

15 From the documents it transpires that Ferdinand's 'Orator' or envoy had been involved in engaging Paolo della Stella and his assistants. Obviously the envoy would have been very much aware of the Palazzo del Principe. In view of the close resemblance between the Palazzo del Principe and the Prague Summer Palace the architectural model Della Stella brought with him from Genoa either documented Doria's residence itself, or was a new design strongly inspired by it. The top floor, inspired on Bramante's Tempietto as illustrated in Serlio's Forth Book, was added only twenty years later; it was probably the result of the deliberations of Hans von Tirol, who was in charge of construction, and Pietro Ferrabosco and Bonifaz Wolmut, who had come from Vienna, presided over by Archduke Ferdinand, as Lord-lieutenant of Bohemia representing his father; cf. Lynch 2017. 

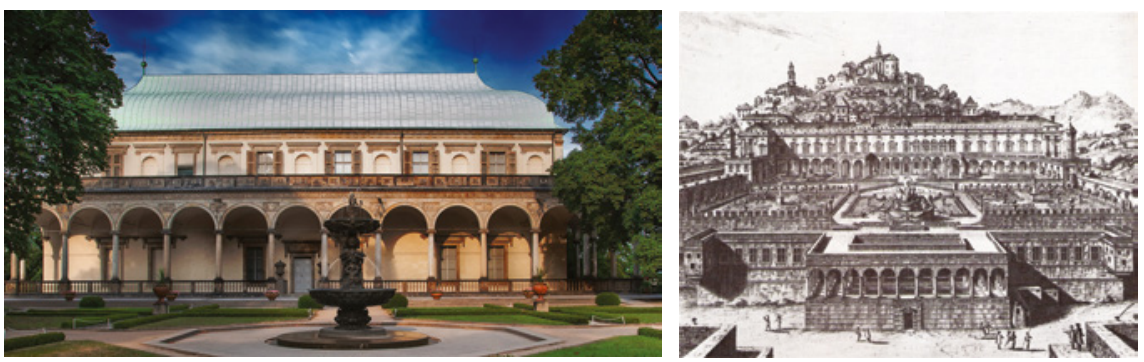

FIGURES 5.17-5.18 The Summer Palace built by Ferdinand I for his consort Queen Anna in the gardens of Prague Castle, compared to the Palazzo del Principe at Fassolo, Genoa; built by Perino del Vaga for Andrea Doria from 1530 onward.

the Hofburg in Vienna, and the Royal Castle at Pressburg (cf. below. Ch. 5.6.2) [below, Figs. 5.79-05.80]. ${ }^{16}$ Holzschuh-Hofer sees a similar stress on the Burgundian aspect of Habsburg heritage in the original colour scheme of the Hofburg, contrasting blue hard stone elements, especially columns, portals and window-surrounds, with a brilliant white undecorated stucco wall surface. ${ }^{17}$ Though she demonstrates clearly that this was an explicit choice of the patron, her interpretation that this colour scheme is a conscious reflection of the Burgundian-Brabantian heritage is less convincing. ${ }^{18}$ But she is certainly right when she points out that the relative simplicity of this scheme represents a fundamental element of Ferdinand's taste: discussing the staircase built 15441545 for the Queen's apartments in the North East wing of the Hofburg, she stresses that:

In the modesty of the architecture $<\ldots>$ once again a subtle, unassuming, noble elegance manifests itself, of a high level of quality. The example of this portal and arch makes clear that there is no contradiction

16 Holzschuh-Hofer 2010; Holzschuh-Hofer 2014(b), pp. 530-540; ibid. pp. 537-539 and ill. VI.48.

17 Holzschuh-Hofer / Beseler 2010; Holzschuh-Hofer 2014(b), pp. 540-544.

18 As in Brabant, the choice for a blue-coloured type of stone for the carved elements of the Hofburg may have been determined more by its being the most suitable for the purpose locally available, than by any wish to remind the Austrians of a dynastic expression in a type of architecture in the Netherlands, which they had never seen and cannot have been aware of. The contrast of white stucco walls and carefully carved architectural elements in pietra serena that is typical for many key monuments of Florentine Renaissance architecture shows that this colour scheme is not exclusive for the Burgundian heritage; it could even be argued that it is a more obvious source for Ferdinand's aesthetic choice. 
between a form reduced to its barest essentials, and a high standard of quality. ${ }^{19}$

Ferdinand's wish for noble simplicity is closely linked to an interest in architecture in the antique manner, as is clear from the direct or indirect encouragement the king appears to have given to Pieter Coecke van Aelst, inciting him to publish a German edition of Sebastiano Serlio's Quarto libro dell' architettura. This Fourth book was first published in 1537, and presented general rules for the five orders, complemented and illustrated by descriptions and measured designs of the most important ancient edifices. The German translation was printed in Antwerp in 1542 with a dedication to the king: in his preface, Coecke relates how Ferdinand's court painter Jacob Seisenegger, after having seen Coecke's Dutch and French translations, had advised him to produce a German edition and to dedicate this to Ferdinand I, who 'above all German princes, not only loved all arts, but also had the best understanding of architecture' [Fig. 5.15-05.16]. ${ }^{20}$
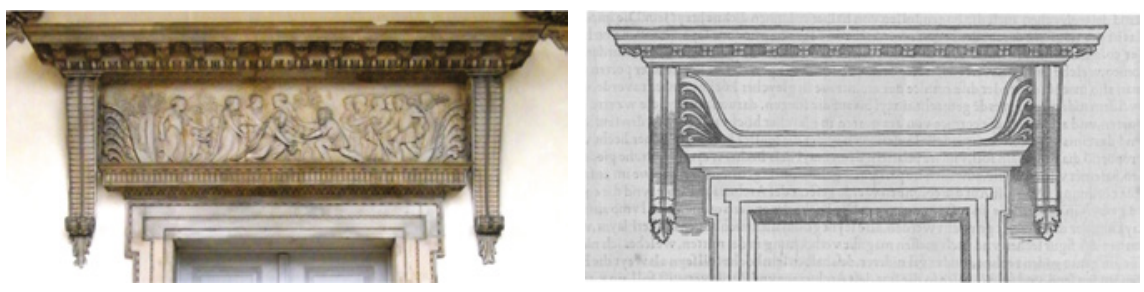

FIGURE 5.19 Entablature of the door surround of Queen Anna's Summer Palace at the Castle at Prague, ca 1540-1545.

FIGURE 5.20 Entablature of a door surround of the Corinthian order in the Forum of Spoleto, from Sebastiano Serlio, Die gemaynen Reglen von der Architectur, Antwerp 1542, fol. 5 ov.

19 Holzschuh-Hofer 2014, p. 92: 'Einmal mehr manifestiert sich in der Schlichtheit der Architektur, die von Ferdinand I. in seiner Wiener Residenz in Auftrag gegeben wurde, subtile, unaufdringliche noble Eleganz auf hohem Qualitätsniveau. Am Beispiel dieses Portals und der Podestbögen wird deutlich, dass eine auf das Wesentliche reduzierte Form und hoher Qualitätsanspruch keinen Widerspruch darstellten. Vielmehr handelt es sich um ein strategisch eingesetztes, einem Programm folgendes Ausdrucksmittel der Ferdinandeische Auftragsarchitektur'.

$20<<\ldots>$ als der, so nit allain uber alle Fursten teuscher nacion alle kunsten lieb haben, sunder auch in der Architectur der aller synnreychest ist', dedication to Ferdinand I in Coecke's edition of Jacob Rechlinger's (Rehlinger) German translation of Serlio's Fourth Book: Sebastiano Serlio, Die gemaynen Reglen von der Architectur uber die funf Manieren der Gebeu, the Antwerpen 1542, fol. Aii r; cf. Krista De Jonge 2004, pp. 278-279, who first drew my attention to this. 
That Ferdinand's interest was immediately taken up by his architects is evident from the exquisite door- and window frames and relief plaques used in the ground floor of the Prague Summer Palace, which date from the early 1540s [Figs. 5.19 and below, 5.79]. ${ }^{21}$ In view of their high quality, these have been sometimes thought to have been imported from Italy. The door surround is particularly interesting, because it derives from a classical overdoor reputedly found at the Forum of Spoleto, and illustrated in Serlio's Quarto Libro, [Fig. 5.20]. ${ }^{22}$

We will see this same awareness of the new, classical style and of developments elsewhere in Europe with Ferdinand's two eldest sons, the Archduke Maximilian, since 1548 titular King of Bohemia, who succeeded his father in 1564 as Holy Roman Emperor and King of Hungary and Bohemia; and Archduke Ferdinand II of Tirol, who as Statthalter or viceroy actually governed Bohemia on behalf of his father and his brother until sometime after the latter's accession.

\subsubsection{Maximilian II: General Interests}

On the whole, the cultural and intellectual patronage of Maximilian II [Fig. 5.21] is a chapter in the history of the Renaissance that still remains to be written. But the relative neglect he suffered has been redressed in recent years by several detailed studies, uncovering and interpreting new source material. These include several studies of his often problematic politics and his equally problematic religious stance, a study of the interests and ethos of the circle of intellectuals he gathered at his court, a modest but rewarding political biography and a volume of essays discussing many different aspects of his life, his reign and his court. ${ }^{23}$ Specifically dedicated to his cultural patronage were studies in the history of music and the theatre, on court festivals and on political propaganda in general, and monographs on Arcimboldo, the best known among the artists at his court, and on the Neugebäude, his principal architectural commission. ${ }^{24}$

\footnotetext{
21 Below, Ch. 5.4.2.

22 This source first identified by Bažant 2006, p. 47.

23 A good survey of the sources and literature on Maximilian II in Paula Sutter Fichtner's biography, Fichtner 2001, pp. 309-333. See also Edelmayer 1988, Edelmayer / Kohler 1992; Louthan 1997.

24 Dunning 1976; Pass 1980; Lindell 1985; Lindell 1999; Schindler 2004; K. Vocelka 1976; R. Vocelka 1976; Kaufmann 1978a; Kaufmann 2009; Lietzmann 1987.
} 


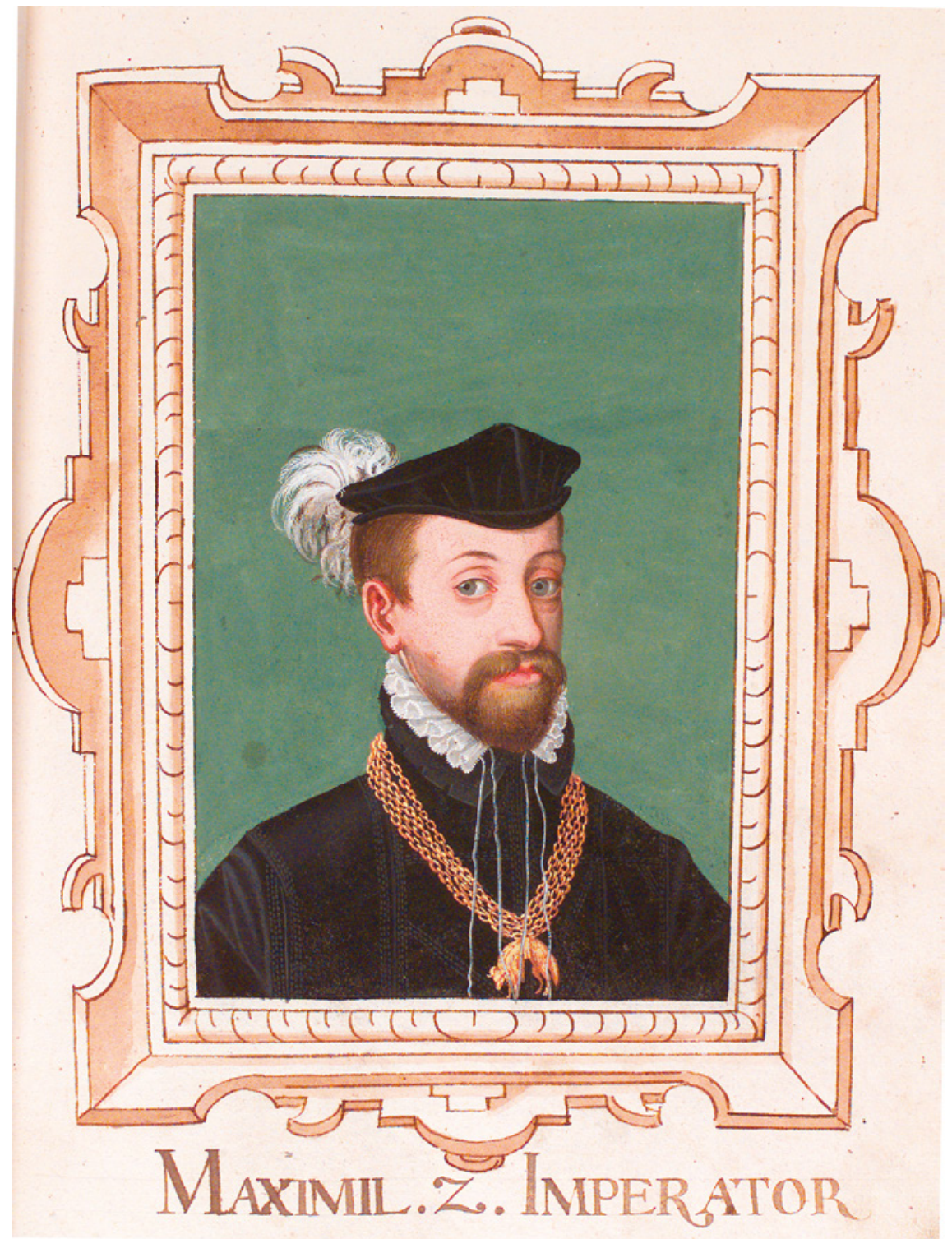

FIGURE 5.21 Emperor Maximilian II, anonymous miniature from the portrait album of Hieronymus Beck von Leopoldsdorf; Vienna, Kunsthistorisches Museum. 
Of particular relevance was the illuminating overview of Maximilian's patronage of the visual arts and his collecting activities presented by Karl Rudolf in $1995 .{ }^{25}$ Based on a careful reading of the available sources and a comparison of Maximilian's activities with those of his cousin, Philip II, this provides a valuable synthesis of the field. Yet a real understanding of Maximilian's patronage will only be possible when a much more complete biography, using the mass of his as yet unpublished correspondence, has thrown more light upon his personal interests and tastes, and has placed these in the context of his time and his very cosmopolitan environment. Until then it is only possible to voice intuitions as to the possible significance of the disparate individual instances of patronage we know of.

The first serious attempt to get some grip on the architectural activity at the Imperial court at the time of Maximilian II was made by Hilda Lietzmann in her invaluable monograph on the Neugebäude of 1987. Though the lack of sufficient and sufficiently coherent documented facts makes it very difficult to come to definitive conclusions, Maximilian's patronage of architecture was sufficiently important to merit specific mention in Crato's funeral oration. Significantly Crato mentions it literally in one breath with his interest in the laying out of gardens and the practice of horticulture:

$<\ldots>$ he had built certain houses and gardens in the outskirts of town, in which for the good of posterity he used to dispose and plant the trees with his own hands. ${ }^{26}$

Maximilian's passion for gardening, for plants, for botany, and more in general for natural history is well-known, and is best exemplified by the preferential treatment given to Carolus Clusius, whom he commissioned to organize a botanical garden. ${ }^{27}$ Maximilian's interest extended beyond the vegetable world, since the wildlife in his gardens and parks was deemed as important as its vegetation, including aviaries, fishponds, and even cages or 'Zwinger' for exotic and ferocious animals, including lions and the celebrated elephant, named

25 Rudolf 1995. It was preceded in 1992 the Vienna dissertation of Katharina Podewils, Kaiser Maximilian II. (1564-1576) als Mäzen der bildenden Künste und der Goldschmiedekunst, which collected and systematically presented a huge quantity of source material on Maximilian's patronage of the visual arts, but has remained unpublished. I am grateful to the author to have made a copy available to me.

26 Crato 1577, p.27: '<... > extruere suburbanas quasdam domos et hortos, in quibus sua manu arbores posteritati profuturas inserere et disponere solebat $<\ldots$. ', as quoted in Lippmann 2006-07, p. 148.

Discussed in detail in Lietzmann 1987, pp. 166-168; Gelder 2011. 
Süleyman, a gift from the king of Portugal which he brought with him on his return from Spain in $1551^{1 .}{ }^{28}$ This naturalistic interest was related to the passion for hunting as a noble pastime which Maximilian shared with most or all of his royal and noble contemporaries. It should be noted here, because it determined the location of his country retreats, and helps explain the huge importance of horses, and consequently of their stabling, at court.

It is obvious that Maximilian's ruling passion for aspects of natural history and for hunting was expressed in the building projects he undertook-among which at least four gardens in the immediate vicinity of Vienna-but it does not imply that he would not have had any interest in the artistic, constructive and engineering aspects of architecture as well. The project he proposed, during his regency of Spain, to canalize the Pisuerga in order to improve the water supply to Valladolid, demonstrates his fascination with civil engineering. He took it sufficiently serious to ask Hans Jakob Fugger to send him some engineer from Augsburg, Wolfgang Hefelder, who was to construct the necessary fountains and machinery according to a design unknown in Spain: thus he hoped to remedy the existing lack of 'good, fresh and plentiful water', which caused 'great distress above all to the poor', and also to leave 'a memorable record of us. ${ }^{29}$ Apparently this did not lead to any concrete measures, but subsequently he commissioned Bustamante de Herrera, the 'visidador de obras reales' or superintendent of the King's Works, to undertake a physical enquiry into the possibilities of rendering navigable all of the principal rivers of Castile, an ambitious project which prefigures the construction, between 1753 and 1791, of the Canal de Castilla by Ferdinand vi and his minister, the Marqués de la Ensenada. $^{30}$

In later years Maximilian would indulge this interest in waterworks in general, and his love of fountains in particular, on several occasions. He would employ the principal aquatic engineer of the period, Hans Gasteiger, to organize the water supply of his greatest enterprise, the Neugebäude. One should

28 Lietzmann 1987, pp. 33-34. The adventures of the elephant and its material remains have been reconstructed by Annemarie Jordan Gschwend (Gschwend 2012).

29 'agua buena, fresca y abundante', the lack of which was 'de gran pesadumbre sobre todo para la gente pobre'; 'un memorable recuerdo de nos', cited in Holtzmann 1903, p. 86; Díaz Medina 1992, pp. 38-54, p. 50. The project appears not to have been finished; the canalization of the Pisuerga was only realized two centuries later.

30 When Herrera found that it would be impossible to do this, but that it might be worthwhile constructing a system of independent canals, a new committee was set up to review his findings. Maximilian applied to his father to find three experienced German engineers to advise on this matter. This committee did its best, as did Bustamante di Herrera, but the project seems to have fallen through because of its technical complexity and because of the return of Maximilian and Maria to Germany; cf. Quijada 1983. 
note that these were trifles compared to Gasteiger's more general responsibilities: as a civil engineer and contractor he was charged with many huge projects, including the water supply of Vienna, the regulation of the Danubewhich he rendered navigable with the help of dredging-machinery of his own invention - and similar projects in the valley of the river Enns. In view of Maximilian's early interest, it is likely that he followed or even supervised such projects closely. ${ }^{31}$

\subsubsection{The Prince as Architect: Education and Literary Sources}

Maximilian's projects for Valladolid suggest that he preferred the more peaceful applications of engineering, as do the gardens he had laid out in and around Vienna. The first of these dated from long before his accession, and even from before the arrival of Strada at court. In about 1556 Maximilian built a small hunting lodge and laid out a garden in the Prater, now a famous park of attractions, but then an island in the Danube across from Vienna covered in woods and rich in game [Fig. 5.65]. ${ }^{32}$ The location, function and particularly the quite distinctive cruciform ground plan of this 'grüne Lusthaus' - a green leisure pavilion-remind one immediately of the star-shaped hunting lodge, Hvězda, constructed at exactly the same time in a very similar spot, the hunting grounds of the White Mountain just outside Prague [Fig. 5.22-5.24].

This small country house, officially named Zum goldenen Stern, was commissioned by Maximilian's younger brother, Archduke Ferdinand. According to contemporary sources it was designed by the Archduke himself. ${ }^{33}$ This raises the question in how far such a claim can be taken seriously, and if so, whether at the Prater Maximilian may have been his own architect as well, a question which may come in useful in trying to attribute the designs of his later, more prestigious projects. And even if that question cannot be resolved conclusively, its discussion helps to sketch Maximilian's architectural frame of reference and therefore may contribute to a better understanding of architectural developments at his court and in his countries.

The theme of the prince exercising himself as an architect or designer was the subject of a conference in Mantua in 1999, Il principe architetto, which discussed such topics as the roles of François I of France and of the Emperor Maximilian I in the execution of their own commissions. In his 'Der Fürst als

31 Gasteiger's career and his role in the water supply of the Stallburg and the Neugebäude is discussed in Lietzmann 1987, pp. 136-139. Lietzmann rightly stresses that Gasteiger undertook these huge projects as a private contractor, rather than as an Imperial official. He did so to the great satisfaction of his patrons: he was ennobled by Ferdinand I in 1561, and Maximilian granted him the freehold of a substantial house in Vienna.

Discussed in detail below, Ch. \#5.3.1.\# 

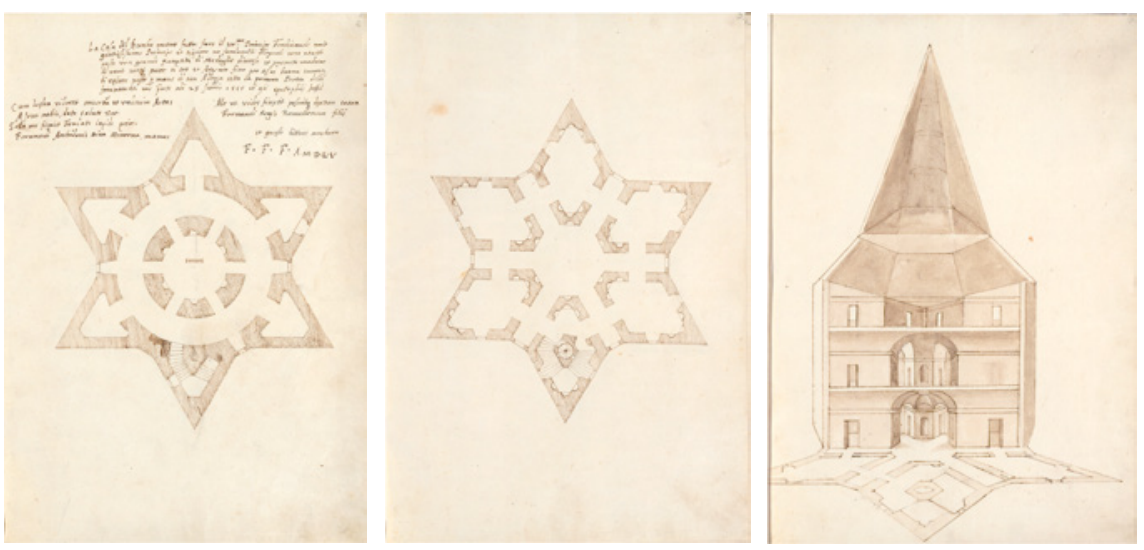

FIGURES 5.22-5.24 Anonymous Italian draughtsman, three of five drawings documenting the design of Hvězda at Prague, after a concept of Archduke Ferdinand II of Tirol: plans of basement and ground floor, and section; Vienna, Österreichische Nationabibliothek, Cod. min. 108.

Architekt', a fascinating evaluation of dilettante architects among the German princes of the sixteenth and seventeenth centuries, Wolfgang Lippmann pointed out that it is difficult to define when exactly we can speak of dilettante or amateur architecture, because the patron in any case would have had an important role in determining the appearance of the architectural projects he undertook. He quite reasonably decided to consider a patron as a dilettante architect whenever he is capable to express his ideas in drawings or sketches, even when such competence is only marginally developed. ${ }^{34}$ That such a patron, for lack of time and professional competences, would not actually have prepared the actual working drawings used to realize his project, is not sufficient reason not to credit him with its concept, its invention.

A set of epigrams in German and in Latin which appears to have been intended for a stone commemorating its construction, unequivocally attributes the design of Hvězda to the Archduke:

33 Schönherr 1876; Lietzmann 1987, pp. 29-31; Chmel 1840-1841, 2, pp. 276-292. On Hvězda, see now Simons 2009, passim.

34 Lippmann 2001, p. 113: 'Als Architekturdilettant wird in den antiken Quellen allein Kaiser Hadrian genannt, auch wenn es schwierig ist, die Kriterien für Architekturdilettantismus genau zu definieren, denn die Auftraggeber haben meistens ihre Bauprojekte mitbestimmt. Meines Erachtens ist dann eine wichtige Voraussetzung gegeben, einen Auftraggeber als 'Architekturdilettanten' zu bezeichnen, wenn er zeichnen kann — selbst dann, wenn diese Fähigkeit unvollkommen ausgebildet ist'. It will be obvious to the reader that the present paragraph owes much to this very stimulating and informative article. Other recent literature on dilettante architecture in the papers of the congress Il principe architetto at Mantua, 1999 [Il principe architetto 2002]. 
Abgemessen, gemacht und circulirt

Darzu mit ersten stain fundirt

Von einem fürsten lobeleich

Ferdinand, erzherzog von Osterreich.
Its proportions were decided, it was designed and drawn with compasses / And then its foundation stone was laid

/ By a laudable prince /

Ferdinand, Archduke of Austria.

The contention that the Archduke actually made the measured drawings for the building is repeated in the other rhymes, as well as in the Latin epigram and in the German prose text, one of which was probably intended to be inscribed in a stone commemorating the foundation of the building. ${ }^{35}$ The contemporary drawings of Hvězda that have been preserved are presentation drawings and are probably not in Archduke Ferdinand's own hand [Figs. $5.22-5.24 ; 5.55] .^{36}$ Technically, the elementary geometry and proficiency in the use of ruler and compasses as taught in the humanist curriculum, would have been sufficient to sketch the basic concept worked out in these designs, when coupled to some interest in architecture. The Archduke certainly possessed this interest, witness the very idiosyncratic character of the building he commissioned. So unless concrete evidence to the contrary would come to light, there is no reason to doubt that Ferdinand was responsible for the concept of this unusual building, including its proportional system. Of course this does not imply that he would have designed it without professional help and that he himself would have made — or even could have made—the detailed working drawings necessary to construct it. ${ }^{37}$

35 First published in Schönherr 1876; JdKH 11, 1890, II, p. CLV, Regest 7143; discussed in Lippmann 2001, p. 117; and Simons 2009, p.105. The other passages stressing Archduke Ferdinand's participation read: <in 1555> 'Hat disen stain legt vnd fundirt / Das werk erdacht vnd circulirt / Mit seiner tuyren rechten hant / Von Oesterreich erzherzog Ferdinand' and: '<On 27 June 1555> haben der durchlauchtigiste, hochgeborn fürst vnd herr, herr Ferdinand, erzherzog zu Osterreich $<\ldots>$ gegenwurtig werk selbst erdacht, mit aigner hand abgmessen vnd circulirt, den ersten stain in das fundament gelegt, demselben werk den namen zum Gulden Stern gegeben vnd [es] damit geeret'.

36 ÖNB-Hs, Cod. min. 108. The set consists of plans of all floors and a section (no elevation); both their character, their state of preservation and the Italian inscription on the first plan strongly suggest that it was intended to document the design for posterity; perhaps it was made on the occasion of the laying of the foundation stone the inscription refers to, or of the completion of the building.

37 Below we shall encounter some other examples of the topos-derived from classical sources-presenting a prince designing something or planting a tree etc. 'with his own hand'. This may incline one to think that Ferdinand's inscriptions were mere variations on the topos and therefore must necessarily have been false. But that seems unlikely: carving a deliberate untruth into stone-or even just to write it down—for posterity to read 
The stress laid in this text on 'measuring' and 'compassing', which presents the building almost as the solution of a problem of applied mathematics, demonstrates that a certain esprit de géometrie must have been among the Archduke's motivations. As one of the disciplines of the quadrivium geometry was an essential element in the curriculum, and there can be no doubt that both Maximilian and Ferdinand had studied it in detail..$^{38}$ That this curriculum also included learning to draw is very likely: in his Libro del Cortegiano of ${ }_{1528}$ Baldassare Castiglione had presented the knowledge of drawing, painting and sculpture as an accomplishments of his ideal gentleman. Though he discusses these on a rather elevated, theoretical and even metaphysical level, he begins his disquisition by indicating the practical use of painting:

In fact, from painting, which in itself is a most worthy and noble art, many useful skills can be derived, and not least for military purposes: thus a knowledge of the art gives one the facility to sketch towns, rivers, bridges, citadels and fortresses and similar things, which otherwise cannot be shown to others even if, with a great deal of effort, the details are memorized. ${ }^{39}$

seems pointless. In fact, if the topos of the do-it-yourself prince is sufficiently attractive and popular, it may actually have incited a real prince to try and live up to the example it was intended to provide. So one should be wary to assume that these inscriptions were pure flattery, and avoid the common prejudice that holds that princely or noble blood automatically precludes one having any artistic talent and any wish to exercise it.

38 Simons 2009, p. 37 refers to an illustrated manuscript from Ambras, identified in an old label as 'Matematica Manuscripta Archiducis Ferdinandi in Inspruck. Dilligentissime conscripta a suo Praeceptore', reason why it has been considered as an old 'school book' of Ferdinand II of Tirol; this tradition was criticized already by Hirn 1885, I, pp. 9-10, n. 2 who noted that it included a section on the Gregorian calendar reform. Yet as a scrapbook or compendium it might possibly be evidence of a continuing interest in mathematics on the part of Maximilian's brother. Mazal/ Unterkircher 1963 relate it, however, to their nephew, Archduke Ferdinand of Inner Austria, afterwards Emperor Ferdinand II. A more precise inspection of the volume (Vienna, ÖNB-HS, Ser. $n$. 2632) might possibly solve the problem; at present it can merely serve to indicate an interest in mathematics with at least one sixteenth-century member of the House of Austria.

39 Book 1, XLIX; Castiglione/Bull 1967, p. 97; Castiglione/Bonora, p. 93: 'Non mancarono ancor molti altri di chiare famiglie celebrati in quest'arte; della qual, oltre che in sé nobilissima e degna sia, si traggono molte utilità, e massimamente nella guerra, per disegnar paesi, siti, fiumi, ponti, ròcche, fortezze e tai cose; le quali, se ben nella memoria si servassero, il che però è assai difficile, altrui mostrar non si possono'. It should be noted that Castiglione talks about knowledge and understanding, not the actual practice, of the fine arts- this in contrast to the practice of literature and music, in which his ideal courtier was consummately accomplished. 
From occasional remarks in the sources it appears that both Ferdinand and his elder brother did indeed know how to draw. Both would in later life be reported to engage in various artistic and scientific pursuits: Ferdinand knew how to blow glass and worked at the lathe, and Maximilian was reputed to draw, to be interested in alchemist experiments and to work in precious metals. We have already seen that he was particularly interested in civil engineering. ${ }^{40}$

It seems likely that the young Archdukes had developed these tastes and talents because the training in design and manual exercise had been an integral part of their education. As yet there is little information on the exact curriculum of Maximilian, his younger brother and the young noblemen that had been selected to be educated with them. ${ }^{41}$ But though we cannot tell with certainty what they learnt, what books they read, what interested them, some idea of it can be deduced from the ideas current in the period, the themes we know were of interest to their peers, the people they met, the books and other materials that were available to them.

One of the objects that certainly were available to them was the Weißkunig, the romanticized autobiography of their great-grandfather, Emperor Maximilian I. Though we have no positive proof that their tutors did indeed avail themselves of it, I think there can be little doubt that it played an important role in establishing the curriculum of his young great-grandsons. ${ }^{42}$ In some

40 Hirn 1885 , I, p. 8 refers to a notebook, a desktop, drawing paper and a drawing board ('ein ungeschrieben Buch, Pultbretter, Reispapier, Reisbrettsteften' that crop up repeatedly in the account books of the small school instituted for Maximilian, Ferdinand and the Edelknaben with whom they were educated. According to Strada Maximilian II himself highly valued a competence in drawing, which he had taught to his sons in Strada's studio (Doc. 1566-03-01; cf. below, Ch. 11.5).

41 There is very little known about the education that Maximilian and Ferdinand received; the relevant older biographies give some information (Holtzmann 1903, pp. 16-26; Hirn 1885, I., pp. 4-10; BIBL 1929, pp.25-32; Fichtner 2001, pp. 7-12; Simons 2009, pp. 32-39) from which it results that the young Archdukes had good, but not necessarily brilliant teachers: in fact most of them are quite obscure (the few better known ones, such as Kaspar Ursinus Velius and Georg Tannstetter, died before Maximilian was eleven years old). Hirn sums up: 'Aus all diesen Einzelzügen resultiert ein Bild guter, häuslicher Erziehung, wie es ein wohl situiertes, bürgerliches Patrizierhaus jener Zeit durchwegs aufzuweisen hatte'. He also points out (p. 4) that Ferdinand I personally supervised his sons' education, and doubtless participated in it to the extent his itinerary allowed. As a young man he himself had spent three years at the court of his Aunt Margaret of Austria in the Netherlands, where he met Erasmus, who personally presented him with a copy of the second edition of his Institutio principis christiani, the beginning of a correspondence which lasted unto Erasmus' death (Kohler 2003<a>, pp. 56-57; Kohler 2003<b>).

42 Maximilian I/ Treitzsauerwein/ Schultz 1888. Der Weißkunig was written at the suggestion and partly at the dictation of Maximilian I himself by his secretary Marx Trautsauerwein, and illustrated with woodcuts by Leonard Beck, Hans Burgkmair, Hans Schäuffelein and 

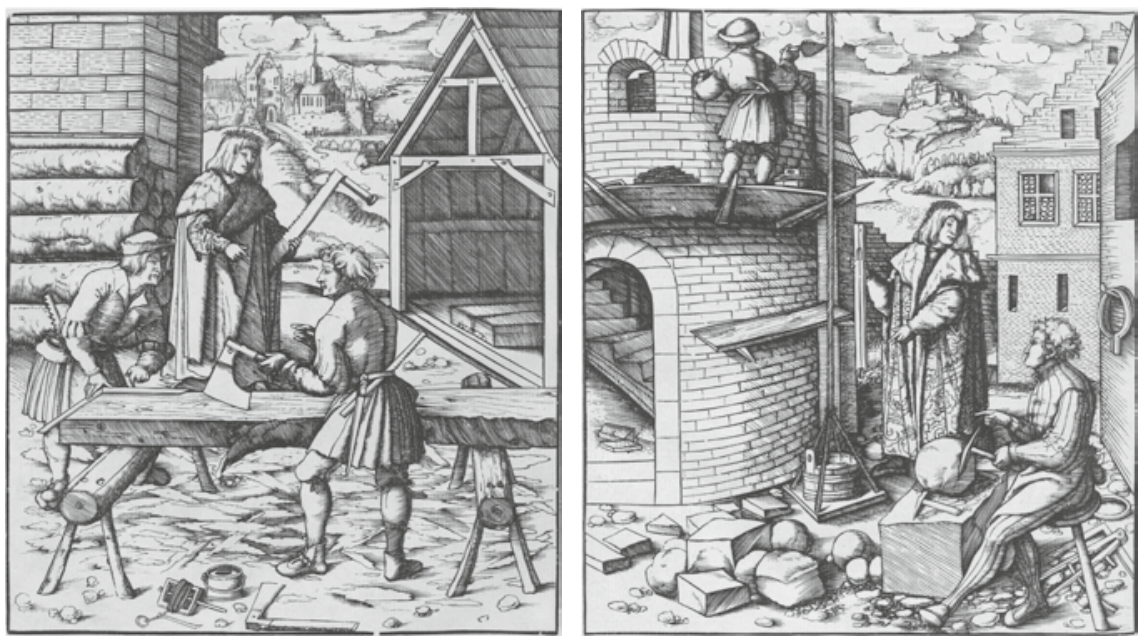

FIGURES 5.25-5.26 Leonhard Beck (ca 1475/80-1542), 'How the young White King learns to build in carpentry' and 'How the young White King learns to build in stone', woodcuts first published in Marx Trautsauerwein, Der Weißkunig, Vienna 1775 .

ways the Weiß-kunig can be considered as an educational treatise for princes, a Fürstenspiegel, because Maximilian paid as much attention to the stages in his intellectual development as to his adult prowess. The Weißkunig explicitly documents and illustrates his learning, not only the rudiments of the noble art of painting, but also those of several manual crafts, including those of the stonemason and the carpenter [Fig. 5.25-5.26].

Recent research has indicated that Maximilian I in fact did possess certain competences in this field and that his contribution to the design of the tomb he planned for himself in Innsbruck was of greater impact than had been realized. ${ }^{43}$ His grandson, Ferdinand I, who commissioned Melchior Pfintzing

Hans Springinklee. Ferdinand I engaged himself to continue it, but it was first published only in the eighteenth century (Vienna 1778). But the text and illustrations (or proofs of the woodcuts based on them) were kept in Innsbruck and thus were available to the young Archdukes and their tutors, cf. Werke für die Ewigkeit 2002, pp. 11-12. Both the authors of this catalogue and Simons 2009, pp. 32-34 have discussed the influence of the example of Maximilian I and the various works he had commissioned on the younger generations of the House of Austria. Gottlieb 1900, p. 109 has shown that many of the over three hundred books and manuscripts from Maximilian's library that were kept in the Hofburg at Innsbruck, of which an inventory was made in 1536 , were actually used by members of the dynasty in the 1530 s and 1540 .

Günther 2002. 
to complete the unfinished Weißkunig, must have been eager to educate his children according to the precepts of their illustrious ancestor. In that they were possibly also confronted with the works of their great-grandfather's favourite artist, Albrecht Dürer. Besides the monumental eulogy of Maximilian's reign, the Ehrenpforte, these included three influential treatises. Dürer's treatise on the perfect proportion of the human body may not have come high on the reading list provided by the boys' tutors, but the other two would have stood a better chance. The first, Underweysung der Messung, mit dem Zirckel und Richtscheyt, in Linien, Ebenen unnd gantzen corporen (Nuremberg 1525) could serve, perhaps in Camerarius' Latin translation of 1532, as a practical complement and commentary on Euclid, but it also was of immediate practical value for the practice of architecture. Thus the second topic of the first section, the Schneckenlinie or snail's line, basically explains the construction of the volute of the Ionian capital. Likewise the third section, 'Von den Corperlichen dingen', i.e. about three-dimensional objects, opens with the design of columns, pilasters and obelisks, including the piers of a Gothic church, but paying much more attention to the geometrical base of the classical column, including the calculation of the entasis and the proportions of capitals, bases and pedestals.

As future princes and generals, the young Archdukes also may have studied Dürer's treatise on fortification, Etliche vnderricht, zu befestigung der Stett, Schlo $\beta$ vnd Flecken, which had been published in Nuremberg in 1527 , and in which the laws of geometry were applied to an eminently practical topic. ${ }^{44} \mathrm{It}$ would be interesting to know whether they read more about architecture and fortification, and if so, what. At the peace conference at Le Cateau-Cambrésis Cardinal Granvelle had taken the English commanders to task for their neglect of the newest developments in warfare, which had led to their loosing Calais to the French. It was this that moved Sir William Cecil, Elizabeth's prime minister, to ask his agents on the continent to scout for capable engineers who might be tempted to come to England: Jacopo Aconcio's transfer to London, about whom more below, was a first result. But he also asked them to inspect suitable examples on the spot and to collect documentary material. He moreover asked Sir Nicholas Throckmorton, the Ambassador in France, for lists of available books on the topic, which he was studying himself: 'I am now and then occupied with Vitruvius De Architectura; and therefore if there be any writers besides Vitruvius, Leo Baptista [Alberti] and Albert Dürer (all which three

44 In his dedication to Ferdinand I, Dürer claims that he had written it specially for him: 'Dieweil sich nun zudregt das E.Mt. etlich stett und flecken zu befestigenn verschaft hat...'. 
I have) I would gladly have them.45 It can be assumed that these authors were also read or at least occasionally consulted at the court of Ferdinand I.

We do not know whether these readers included the young Maximilian and Ferdinand, but it is not unlikely. In the 1550 s both showed themselves capable of reading architectural drawings, which implies that, for study or as a pastime, they had made themselves acquainted with at least some of the literature pertaining to architecture that became available in the 1540 os and $1550 \mathrm{os}$. In addition to Euclid and Dürer's geometry they might have studied a simple manual of perspective, such as Jean Pélérin's illustrated De Artificiali Perspectiva (Toul 1505, reprinted 1508, 1509, 1521) [Fig. 5.27]. ${ }^{46}$ Probably their early training would not (yet) have included a complex and difficult text such as Vitruvius itself, but they might have studied the woodcuts in the first illustrated editions, published by Fra Giovanni Giocondo in 1511 and by Cesare Cesariano in 1521, the
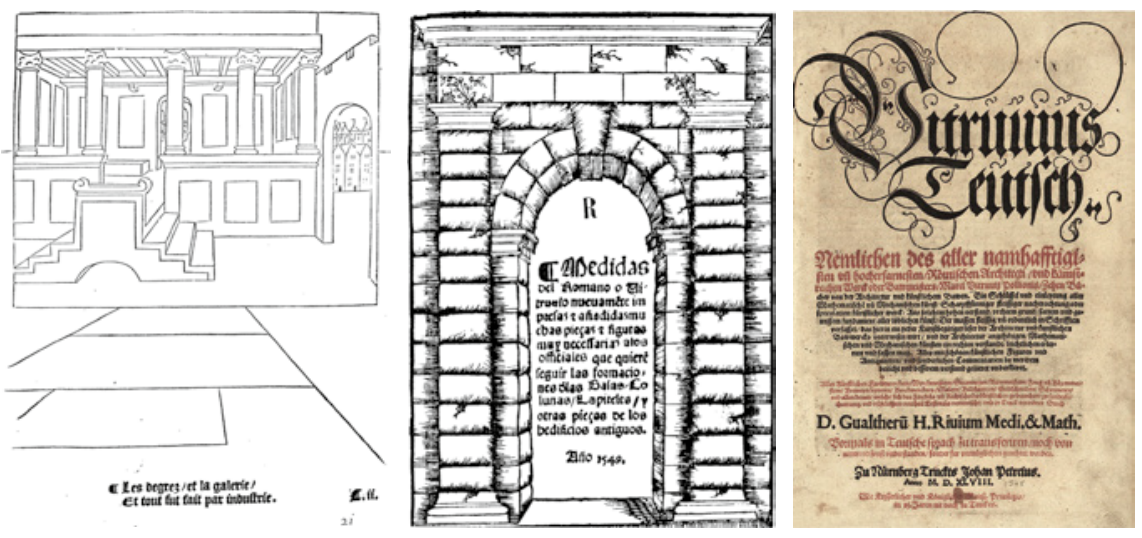

Figure 5.27 'Les degrez / et la galerie', in Jean Pélérin's De Artificialia Perspectiva, Toul 1521.

FIGURE 5.28 Title page of Diego Sagredo, Medidas del Romano, Toledo, 1549.

FIGURE 5.29 Title page of Walther Ryff, Vitruvius Teutsch, Nuremberg 1548.

45 Letter dated October 12, 1559, cited in White 1967, p. 430. Vitruvius was at that time available in various Latin editions, the illustrated Italian translation by Cesare Cesariano ( $D e$ Lucio Vitruvio Pollione De Architectura, Como 1521), the French translation by Jean Martin (Architecture, ou Art de bien bastir, Paris, 1547) or the German translation by Walther Rivius (Vitruvius Teutsch, Nuremberg 1548), whereas the splendid Italian translation by Daniele Barbaro and illustrated by Palladio had just been published (1556). The Latin original of Alberti, De Re Aedificatoria was available only in manuscript, or in the Italian translations by Pietro Lauro (Venice 1546) or, a more likely candidate, that by Cosimo Bartoli (Florence 1550).

46 Parts of its contents were popularized by their inclusion in one of the earliest illustrated encyclopaedias, Gregor Reisch's Margarita Philosophica, first printed in Freiburg in 1503. 
first Italian translation. Moeover they may have actually read later abbreviations and elucidations, for instance Diego de Sagredo's Medidas de Romano, a dialogue explaining the basics of Vitruvian architecture that was first published in Toledo in 1526 and was repeatedly reprinted in French translations [Fig. 5.28]. ${ }^{47}$

The 1540 s saw a strongly increasing interest in the theory and practice of classical architecture: it produced the scholarly translation of Vitruvius by Daniele Barbaro, illustrated by Palladio, in 1556; the French translation, Architecture ou Art de bien bastir, by Jean Martin (with illustrations by the famous sculptor, self-styled 'Jean Goujon, studieux d'architecture'), also in 1547, and a German one a year later, Vitruvius Teutsch, by Walter Hermann Ryff (or Rivius) [Fig. 5.29], most of which were themselves influenced by the learned commentary on Vitruvius' often obscure text by the French humanist Guillaume Philandrier. ${ }^{48}$

The same decade saw the publication of several new editions and translations of Alberti's De Re aedificatoria, as well as, from 1537 onward, that of several books of the extremely influential illustrated treatise of Sebastiano Serlio, which were almost immediately reprinted and translated in several languages, largely in Antwerp by Pieter Coecke van Aelst. ${ }^{49}$ The boom of architectural publishing of the period was probably stimulated by the tremendous success

47 M. Vitruvius per Iocundum solito castigatior factus cum figuris et tabula ut iam legi et intelligi possit, Venice (Tacuino) 1511; Di Lucio Vitruvio Pollione de architectura libri dece traducti de latino in vulgare affigurati, commentati et con mirando ordine insigniti, Como (Gotardus de Ponte) 1521 ; Diego de Sagredo, Medidas del romano neccessarias a los oficiales que quieren seguir las formaciones de las basas, columnas, capiteles y otras pieças de los edificios antiguos, Toledo, en casa d[e] Ramón de Petras, 1526, repeatedly reprinted; translated as Raison D'architecture antique, extraicte de Victruve et autres anciens architecteurs nouvellement traduit Despaignol en Francoys: alutilite de ceux qui se delectent en edifices, Paris, S. de Colines, s. d. [1536]; reprinted 1539, 1542 and later.

48 I dieci libri dell'architettura di M. Vitruvio tradutti et commentati da Monsignor Barbaro eletto patriarca d'Aquileggia, In Vinegia per Francesco Marcolini, 1556; Architecture ou Art de bien bastir, de Marc Vitruve Pollion Autheur Romain antique: mis de Latin en Francoys, par Ian Martin Secretaire de Monseigneur le Cardinal de Lenoncourt, Paris, Jacques Gazeau, 1547; reprinted 1572 and later; <Walther Ryff>, Vitruvius Teutsch. nemlichen des $<. . .>$ Marci Vitruvius Pollonis zehen Bücher von der Architectur und künstlichem Bawen: ein Schlüssel und Einleitung aller mathematischen und mechanischen Künst $<\ldots .$. Erstmals verteutscht und in Truck verordnet durch Gualtherum H. Rivium <...>, Nürnberg [s.n.], 1548; Ryff was earlier involved in a Latin octavo edition printed at Strassburg in 1543; Guillaume Philandrier, In decem libros M. Vitruvii Pollionis de architectura annotationes $<\ldots$. , Rome, G. Andrea Dossena, 1544, reprinted 1545 (twice!) and 1557, and added to Vitruvius editions of $155^{0}$ and $155^{2}$.

49 By 1560 these included the first five books of the treatise as well as the Extraordinario Libro in various editions; cf. Bury 1989. 
of Serlio's volumes, and it continued in the next decades. Hans Blum's Quinque columnarum exacta descriptio atque delineatio $<\ldots>$ of 1546 , a simple introduction to the design of the five orders proved another bestseller. ${ }^{50}$ It was soon followed by the first print series of ornamental and architectural designs by Du Cerceau, Pietro Cataneo's I primi quattro libri dell'architettura, a treatise on military and civil architecture (Venice 1554), Du Cerceau's Livre d'architecture published in two volumes in 1559 and 1561, and Philibert de l'Orme's more practical Nouvelles inventions pour bien bastir of 1561 . Of far greater and more lasting international influence would be, finally, Vignola's Regola delli cinque ordini d'architettura of 1562 and Palladio's I quattro libri dell'architettura of 1570, but these came probably too late to have had great influence on Maximilian's attitude to architecture in the last decade of his life. ${ }^{51}$

The boom of architectonic publishing in the 1540 s and 1550 s indicates that it was a trendy subject; it can hardly be a coincidence that the first examples of 'correct' Vitruvian architecture to the North of the Alps date from this period. Duke Albrecht $\mathrm{v}$ of Bavaria took the trouble to obtain most or all of the works cited here, often in multiple editions, and supplemented them by a great quantity of drawings, prints and print-series documenting both ancient and contemporary architecture, as is clear from a slightly later list of the architectural holdings of the Munich Kunstkammer ${ }^{52}$ So it is perfectly possible that copies of many of these publications had also arrived at the Imperial court, and that some of them actually came to the notice of Albrecht's brothers-inlaw. At a later date Archduke Ferdinand's Kunstkammer included several of these volumes, so it cannot be excluded that he may have acquired some of them early enough to have been of some use in the planning of Hvězda. Having bought them, or even seen them, does not imply that the Archdukes actually read them, let alone studied them in detail: that they may well have left to their humanist and professional advisers. But the fact that so many of these treatises were illustrated implies that, even when they were not actually read, they still could have an immediate influence on those consulting them.

5o Hans Blum, Quinque columnarum exacta descriptio atque delineatio $\langle\ldots\rangle$, and Von den füff Sülen Grundlicher bericht <...>, both Zürich [Christoph Froschauer] 1550; id., Les cinq coulomnes de l'architecture, ascavoir, la tuscane, dorique, ionicque, corinthie, et composite $<\ldots>$, Anvers [Hans Liefferinck], 1551, reprinted Lyon 1565, and into the late seventeenth century.

$5^{1} \quad$ Many of these treatises, including several of Du Cerceau's print series, now digitally available at the site Architectura, of the Centre d'Études Supérieures de la Renaissance of Tours (http://architectura.cesr.univ-tours.fr).

$5^{2}$ Dating from ca $1580-1581$; it is discussed by Peter Diemer in his chapter, 'Verlorenverstreut-bewahrt. Graphik und Bücher der Kunstkammer', in Diemer/Diemer/ Sauerländer 2008, 3, pp. 223-252, who prints the full, annotated text in an appendix, pp. $240-25^{2}$. 

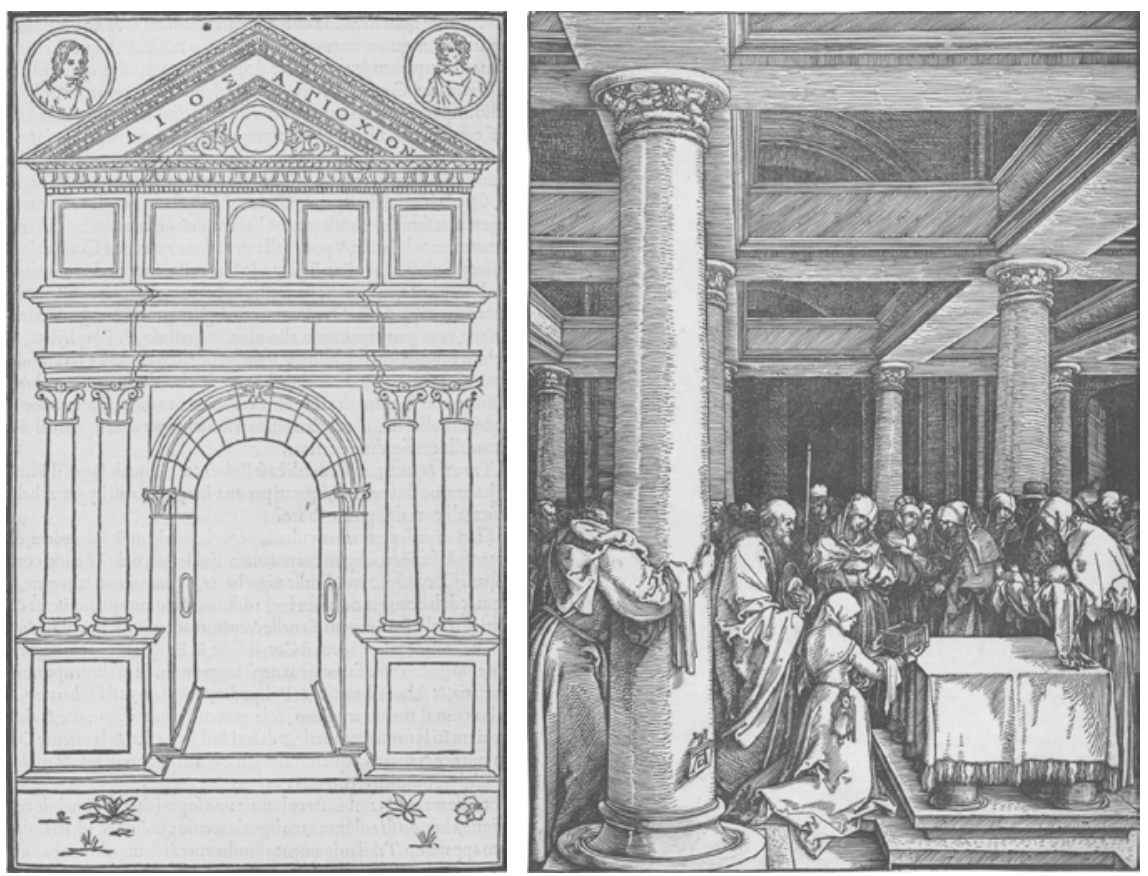

FIGURE 5.30 The gatehouse of a palace, woodcut from the Hypnerotomachia Poliphili, Venice 1499 .

FIGURE 5.31 Albrecht Dürer, The Presentation of Christ in the Temple, woodcut, ca 1505.

Such more or less 'professional' literature was not the only potential source for the young Archdukes' approach, as patrons, to architecture: passages on building and the arts in the Christian and classical texts they studied as part of their curriculum may also have played a role. One thinks of references to biblical texts such as the description of Solomon's projects and the description of the Heavenly Jerusalem, or of Cicero's description of a house suitable for a gentleman in his De officiis, a standard educational text at the time. Accessible works of art, such as Dürer's print of The Presentation of Christ in the Temple (ca 1505) [Fig. 5.31], made the objects of such descriptions more tangible.

The monuments of Antiquity, as described in classical texts—such as the younger Pliny's descriptions of his several villa's-or their remains as rediscovered since the second half of the Quattrocento in Rome and elsewhere, may have fired the Archdukes' imagination, in particular those of the monuments realized by the Roman Emperors, whose successors they considered themselves to be. Images of these had become available in Serlio's Third Book and elsewhere [Fig. 5.32]. They may even have been familiar with the famous illustrated romance, the Hypnerotomachia Poliphili, first published in Venice in 
1499, but again very popular in the 1540s. This book can stand as an excellent illustration of the link between court culture, humanist learning and knowledge of classical architecture [Fig. 5.30].

\subsubsection{The Prince as Architect: Practical Experience}

The architectural frame of reference that Maximilian could draw upon in his patronage was not, however, determined solely or even primarily by theoretical treatises and more or less fanciful woodcuts. It is important to ask what architecture he had actually seen by 1555 , and also which of these examples would have most impressed him, and why. A brief sketch of his itinerary will serve the purpose..$^{53}$

Maximilian was born in the Vienna Hofburg, but he lived the first decade and a half of his life largely in Innsbruck, except for a year spent in Vienna when he was about ten years old. Only from 1543 onward did he begin to travel, at first in his father's retinue, attending the 1543 Nuremberg Diet and visiting Prague for the first time. The next four years he spent in the retinue of Charles $v$, beginning with the French campaign ending in the capture of Soissons and the peace of Crépy, followed by a long sojourn at the Imperial court at Brussels (September 1544-March 1545).

Fortification being an important subject for a prince and warrior in training, he will have been able to see for himself, or at least in its plans, the fortifications of Antwerp developed by the Italian architect Donato de' Boni, who also designed the Imperial gate to that city which was being built at the time [Fig. 5.33]. Perhaps he also heard something about the plans of Charles v and of his aunt Mary of Hungary for their respective residences in Brussels and Binche that were to be realized in the followingyears. Travelling with the court and the army of Charlesv during the months preceding and following the battle of Mühlberg (24April1547) he criss-crossed central and southern Germany, where he visited both friendly courts—-such as Munich, Stuttgart, Jülich and Dresden — and the principal Imperial towns, such as Aix-la Chapelle, Cologne, Worms, Speyer, Regensburg, Ulm, Nuremberg and Augsburg. With his father he visited most of the Habsburg dominions in and bordering on Germany, including Moravia, Silesia and Lusatia.

In 1548 Charles V and Ferdinand I agreed to a marriage settlement between Charles' daughter Maria and Maximilian, who was given the title of King of Bohemia on the occasion. In June of that year Maximilian travelled from Augsburg, where he had been attending the famous geharnischte Reichstag, through Munich, Innsbruck, Bolzano and Trent to Mantua, and from there 

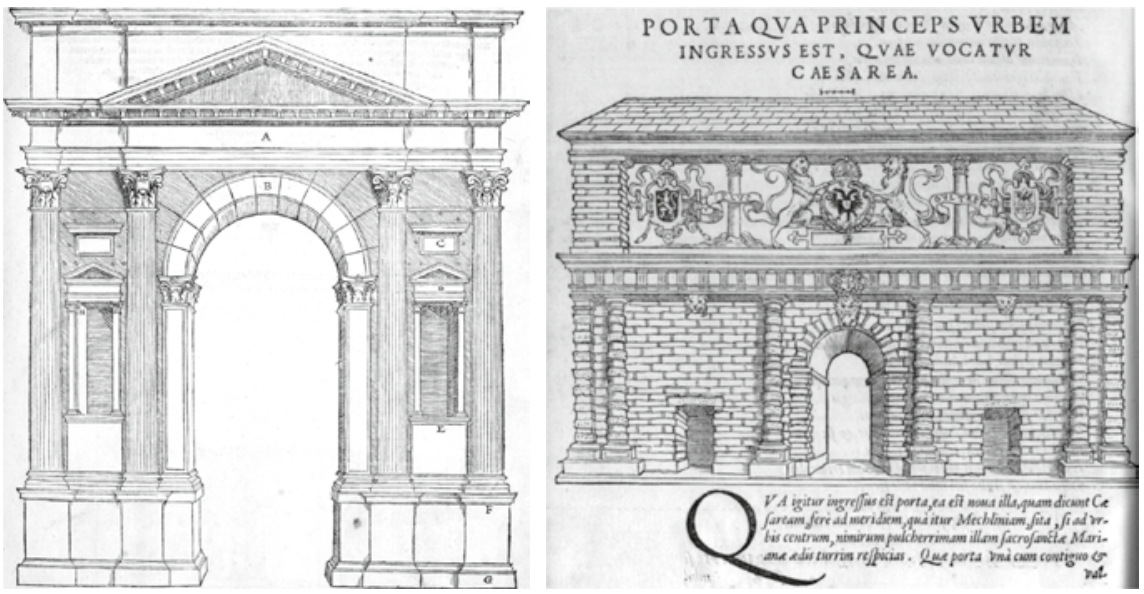

FIGURE 5.32 Sebastiano Serlio, the Arch of the Gavii at Verona, from the first edition of his Terzo libro, Venice 1540.

FIGURE 5.33 Donato de' Boni, Imperial Gate, Antwerp, ca 1545, contemporary woodcut.

through Cremona and Lodi to Milan. In all these places he only remained one or two days, even at Milan. From there he travelled to Genoa, where he stayed for five days in the seaside villa, the Palazzo del Principe, at Fassolo just outside the city gates [Fig. 5.18]. As we have seen, this light-hearted, airy villa with its splendid decoration and luscious garden had been built in the 1530 s by Perino del Vaga for Andrea Doria, who commanded the fleet that brought Maximilian and his train to Spain. On his return to Augsburg in November-December 1550, and both ways on his trip to accompany his wife and children home from Spain (respectively in June and in November of 1551) he always took this same route, roughly in the same tempo. He never returned to Italy afterwards, and he never saw Venice, Florence or Rome, let alone Turin and Naples. He seems even to have bypassed Verona and its Arena on all four occasions, missing out on the one monumental example of the architecture of Ancient Rome he conveniently might have seen standing. ${ }^{4}$ So his first-hand experience of first-rate contemporary Italian architecture remained limited to Giulio's work at Mantua and the patrician palaces of Milan — among which Domenico Giunti's Villa Simonetta, built for Maximilian's host, Ferrante Gonzaga [below, Ch. 9.10.3, Figs. 9.90-9.91] —and Genoa; it excluded even Sanmicheli's palaces at Verona. This seems not very much; nevertheless it appears to have been sufficient for a

54 He may have seen the preserved Roman ramparts of Tongeren in Belgium, but these, though authentic, can hardly be called imposing. 

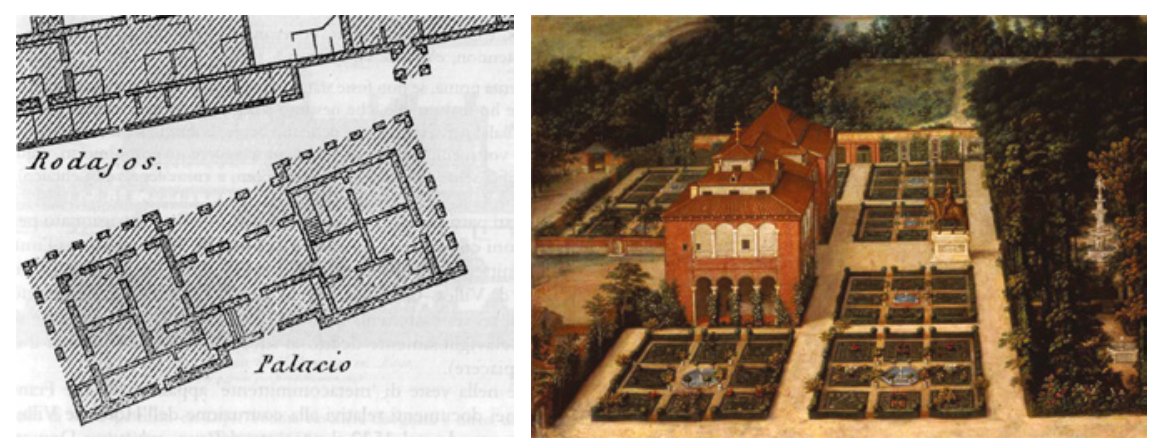

Figures 5.34-5.35 Casa de Campo, Madrid, ca 1519; attributed to Antonio de Madrid (active 1509-1549); plan and bird's eye view.

patron who would at least in one instance consciously attempt to emulate Imperial Rome. But such limited immediate acquaintance with the real thing suggests that the treatises and illustrations listed above may have been of greater import than one might initially expect. ${ }^{55}$

Recently the mutual cultural influence of Spain and Austria has been the subject of various publications; but again, possible influences in architecture can hardly have been the result of first-hand inspection by Maximilian. The more influential buildings, such as Aranjuez and the Escorial, mostly postdate Charles v's reign and Maximilian's Spanish years. From Barcelona Maximilian travelled through Zaragoza to Valladolid, where he was wedded to his cousin Maria on the very evening of his arrival. Valladolid would remain the couple's residence while he was acting as regent of Spain for Charles v. They appear not to have travelled very far from Valladolid, but Maximilian probably saw the Casa de Campo, the small regular villa near Madrid that had been built in 1519 by a courtier of Charles v [Fig. 5.34-5.35]. This had earlier been visited by Francis I when a prisoner in Spain, and had been used by him as a source for the first castle he planned on his return, the Château de Madrid in the Bois de Boulogne. ${ }^{56}$

Maximilian did not visit Charles' one really imperial project, the unfinished palace built from 1528 onward next to the Alhambra at Granada, according to a Roman design obtained through Baldassare Castiglione, and speculatively attributed to Raphael, Giulio Romano and Baldassare himself in turn, but

55 Mario Carpo discussed this theme in a stimulating article, 'How do you imitate a building that you have never seen? Printed images, ancient models, and handmade drawings in Renaissance architectural theory' (Carpo 2001).

$5^{6} \quad$ Marias 1991; Châtenet 2002. 
probably due to Pedro Machuca who was responsible for its construction until his death in 1550 [Fig. 5.36-5.37]. But though Maximilian did not see it with his own eyes, he must have heard about it and have obtained some idea of what it looked like. A set of the plans [Fig. 5.38] must have been available at court with the council charged with the supervision of its completion (the palace was never actually finished). ${ }^{57} \mathrm{In}$ view of his active interest in the projects of civil engineering mentioned above, it is unlikely that he would not have informed himself about what was, after all, Charles v's grandest architectural commission. Its grandeur and purity cannot have failed to impress him.
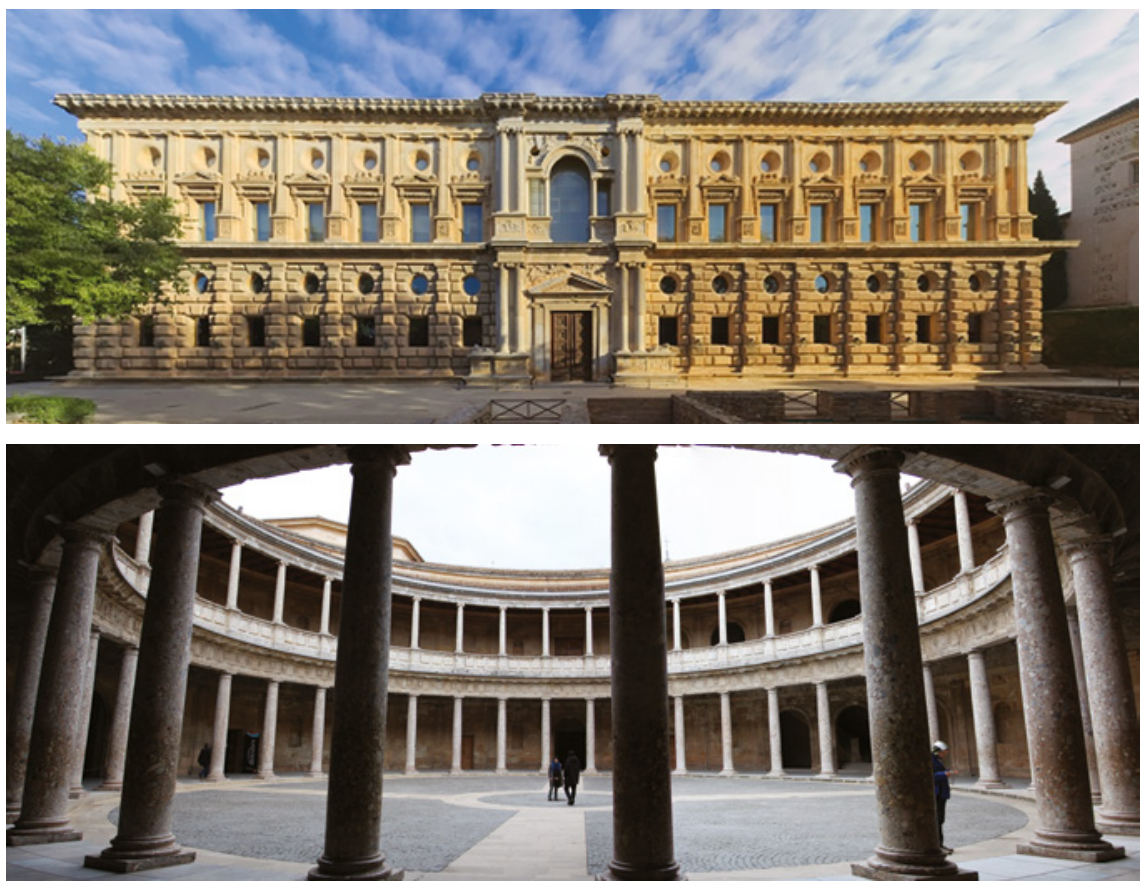

FIgURES 5.36-5.37 The Palace of Charles V at Granada, principal (west) facade and circular courtyard.

57 Rosenthal 1985 . The construction of the palace was continuing in the 1540s; though the day to day running doubtless was left to local authorities, such as the governor, Don Iñigo López de Mendoza, decisions on funding and controversial items of the designs were taken or at least confirmed at court. As representative of his uncle and father-inlaw, Maximilian was formally responsible for such decisions, so he must have been given some basic information on what was after all Charles' grandest commission. Is it a coincidence that in October 1548, very shortly after his arrival straight from Charles' court, one of these controversial points, the design of the huge central Serliana of the upper floor of the south facade, was finally resolved, after six years of relative stagnation? (Rosenthal 1985 , pp. 82 ff., 'The South Window'). 

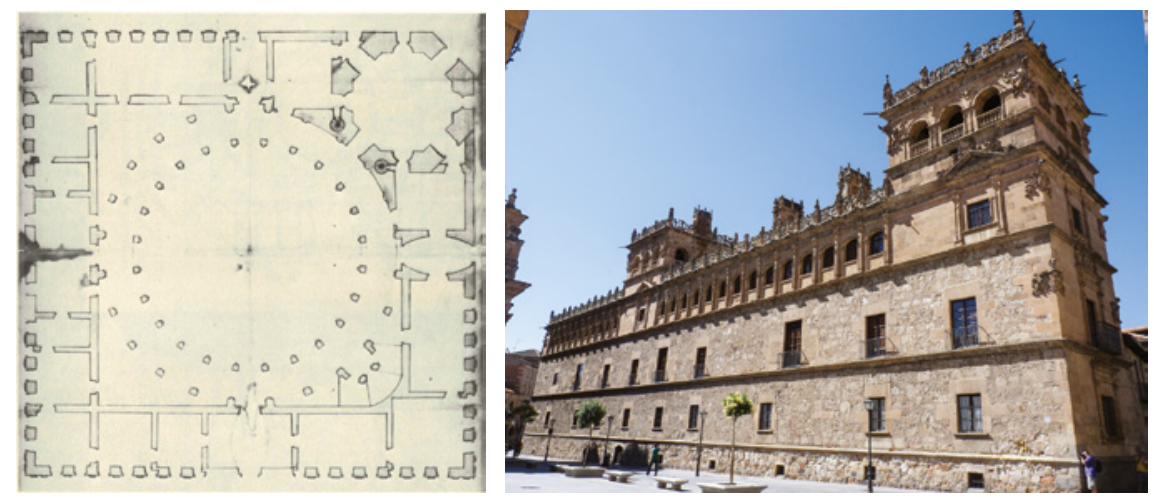

FIGURE 5.38 The Palace of Charles V at Granada, plan.

FIGURE 5.39 Rodrigo Gil de Hontañon, Palacio de Monterrey, Salamanca (1536-39).

Yet it should be noted that most of the recent architecture that Maximilian actually saw in Spain was of a completely different style, the plateresque, an updated version of the Flemish inspired, flamboyant Gothic from the time of the Catholic Kings, classicized by the inclusion of straight lines and Quattrocento ornament. A good example is the Palacio de Monterrey in Salamanca, built in 1536-39 by the foremost Spanish architect of that generation, Rodrigo Gil de Hontañon [Fig. 5·39].

On his return from Spain Maximilian was not permanently established in Vienna, but travelled a lot, mostly within the Erblande and Hungary, and also in South-Eastern Germany, to assist or represent his father in various negotiations and at the Imperial Diet. Only in the summer of 1556 Maximilian and Maria undertook another trip farther afield, to the Netherlands, in order to take leave of Charles v, whose plans to abdicate and to return to Spain had now become concrete. They travelled through Linz, Ingolstadt, Ulm, Stuttgart, Speyer, Worms, Mainz, Koblenz, Bonn, Jülich, Maastricht and Tongeren and were received by Philip in Louvain on the 16th of July and by Charles in Brussels the next day. Their stay was brief, less than three weeks, but eventful, the many festivities including a tournament on 26 July. It doubtless was emotional at least for Maria, who must have been quite conscious that she saw her father for the last time. Though brief, the stay may have given Maximilian the opportunity to update his earlier experience of the flourishing art and architecture of the Netherlands, if only because the representative character of the occasion provided ample scope for artistic endeavour. ${ }^{58}$ 
This update included in any case the stained-glass windows placed by the members of his family in the chapel of the Sacred Sacrament in Sainte-Gudule in Brussels since his last visit: these had been designed by Bernard van Orley and Michiel Coxcie and included elaborate and carefully designed Vitruvian architectural backdrops [Figs. 5.40-5.41]. In view of the dynastic importance of this chapel it naturally incited Maximilian's interest and he would have been particularly eager to see the window dedicated by his parents in 1546 . Now he commissioned an additional window for his wife and himself, and though he probably left its details to the chapter of the church, he must have given them some instructions, if only to continue in the style, and possibly with the same master, Coxcie, who had made the earlier windows. In any case that is what happened. ${ }^{59}$
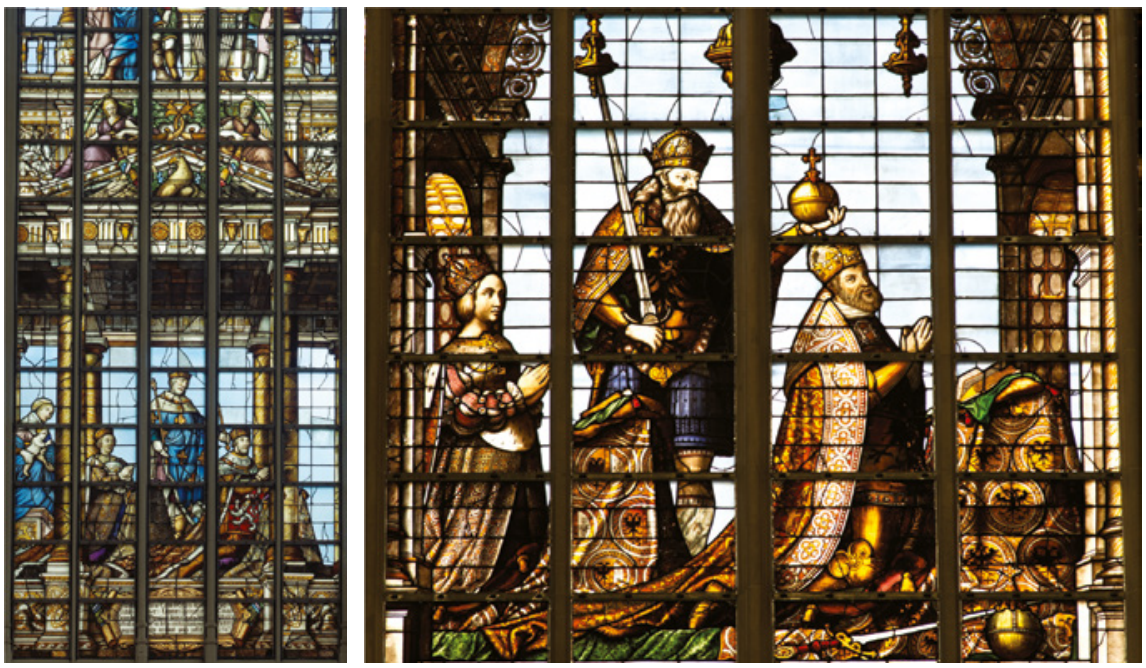

FIGURES 5.40-5.41 Michiel Coxcie, stained-glass window commissioned by Mary of Hungary, 1547; and detail of the stained-glass window commissioned by Charles V and Isabella of Portugal, 1537; both Brussels, Cathedral of Ste Gudule, Chapel of the Holy Sacrament.

Michiel Coxcie was paid for its cartoon on 1 November 1556, the stained-glass worker Pelgrim Rese for its manufacture on 13 June 1557. Unfortunately it was later destroyed, as were the windows donated by Charles V and by Philip II. The chapel was commissioned by Charles v and built 1533-1539; the other windows were given by Charles himself (Michiel Coxcie, 1542), his sister Eleanore and her husband Francis I of France (Barend van Orley, 1540), his sister Catherine and her husband, King John III of Portugal (Michiel Coxcie, 1542), his sister Mary and her late husband King Louis II of Hungary; his brother, King of the Romans Ferdinand I and his consort Anna of Hungary (Michiel Coxcie, 1546); and his son Philip and his consort Maria of Portugal (Michiel Coxcie, 1550). Boogert 1992; the relevant documents published in Lefèvre 1945 . 
In Brussels he also saw Charles' new garden retreat in the Warande next to the Coudenberg palace, and the extraordinary pure and up to date residence that had just been built by Antoine Perrenot de Granvelle, bishop of Arras [Fig. 5.42-5.43]. Charles' odd, pentagonal pavilion was being built after designs by Jacques Du Broeucq, whose works count among the earliest in the style of the High Renaissance realized in the Netherlands. They include Mary of Hungary's residences at Binche and Mariemont (both from 1545), her fortress towns of Mariembourg (from 1546) and Philippeville (begun 1554), which was under construction at this time, and the huge and splendid castle at Boussu in Hainaut, built for one of Charles v's most faithful grandees, Jean de Hennin-Liétard, Count of Boussu, which had been begun as early as 1540 [Figs. 5.44-5.45] ${ }^{60}$
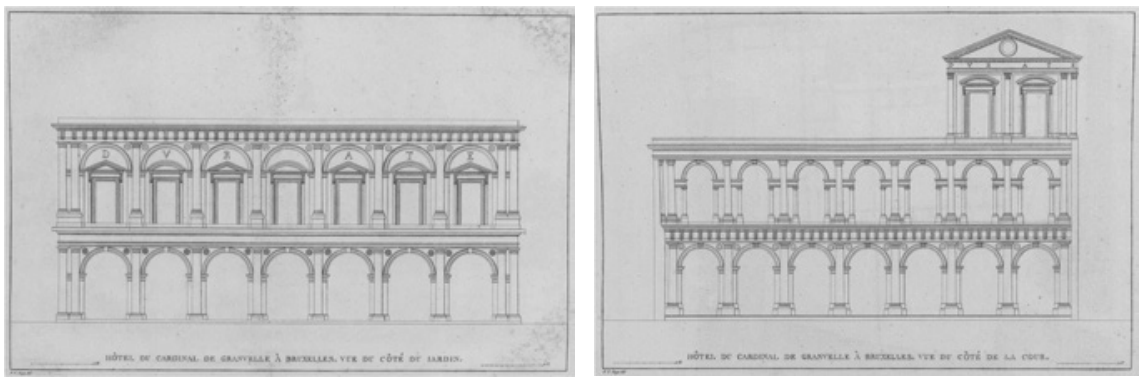

FIGURES 5.42-5.43 Garden and courtyard facades of the Palais Granvelle in Brussels, engraving from P.J. Goetghebuer, Choix des monuments, édifices et maisons les plus remarquables du Royaume des Pays-Bas, Ghent 1827.
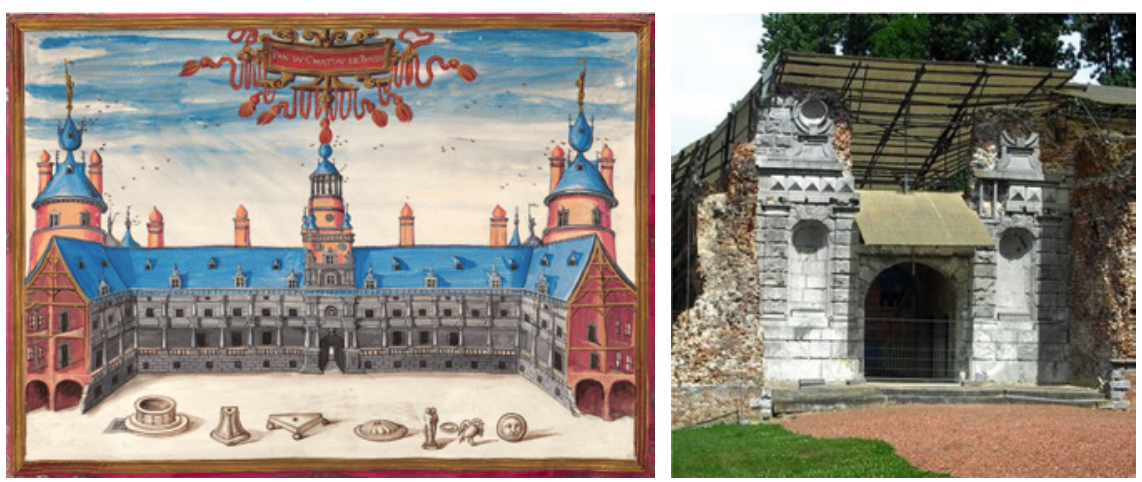

FIGURE 5.44 Adrien de Montigny, View of the courtyard of the Château de Boussu (Hainaut, Belgium), also showing some parts of a dissassembled fountain, perhaps meant to refer to Jean de Hennin-Liétard's antiquarian interests; gouache from the Albums de Crö̈ (ca 1607); Vienna, Österreichische Nationbalbibliothek.

FIGURE 5.45 Château de Boussu: the existing ruin of the entrance portal.

6o On Du Broeucq, see Jacques du Broeucq, Sculpteur et Architecte de la Renaissance 1985; De Jonge / Capouillez 1998; on the Palais Granvelle, De Jonge 2000. 
Maximilian saw few, if any, of these earlier buildings in the new style in person: during his first prolonged visit to the Brussels court, in 1544-1545, Binche and Mariemont had not yet been begun, but by 1556 they had been plundered and destroyed by the French, and his stay in any case was too short and too busy to travel far outside Brussels. But he had seen Boussu during his earlier stay, when Charles and his court paid a visit to see the newly built palace of his old friend in February 1545. Jean de Hennin-Liétard had been one of Charles' commanders in Italy in the late 1520 s, and had been present at the Sack of Rome, when he had been impressed by both ancient and contemporary Roman architecture. His creation predated anything similar commissioned by Charles and Mary in the Netherlands, and its influence on their patronage should not be underestimated. This is underlined by the fact that Philip II, impressed by Boussu during his own visit in 1549, sent one of his architects, Gaspar de Vega, to study and draw it while he was building his first palace in

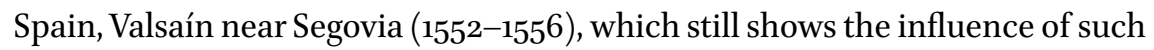
Netherlandish forms of the High Renaissance style. ${ }^{61}$ Moreover Maximilian's other brother-in-law, Duke Albrecht v of Bavaria, owned the 'Ichnographiae zwayer palatien der grossen herren im Niderland Possu und Bins', that is a set of measured drawings of both Binche and Boussu. ${ }^{62}$

In the Netherlands the interest in correctly designed classical architecture was not limited to the court of Charles v and Mary of Hungary. Even more than in their residences at Brussels and Binche, this was exemplified in the festive decorations for the joyeuses entrées of Philip II in the various towns of Brabant and Flanders on his arrival from Spain in 1549, which were commissioned by the town-councils and the guilds of the respective towns. Of course Maximilian, who was replacing Philip as regent in Spain at that time, had not seen these extraordinary examples of dynastic and political propaganda with his own eyes, but in view of their dynastic importance, and given the intensive contacts between his court and those of Charles and Philip, he must have been informed about them. Moreover he could see what they had looked like through a series of detailed descriptions accompanied by splendid woodcut illustrations, again prepared by Pieter Coecke van Aelst [Figs. 5.46-5.47]. Though occasionally overloaded with typically Flemish strap work decoration, in their structure all the triumphal arches, theatres and other temporary decorations lining the streets of Philip's progress, displayed the correct application of the

61 De Jonge / Capouillez 1998, pp. 31-32 and 167-168.

62 According to a list of architectural material in the Munich Hofbibliothek predating Fickler's Kunstkammer inventory of 1597, Bsв, Cbm. cat. 114, p. 20 f, cited in Diemer/Diemer/ Sauerländer 2008, I,1, p. 57, nr. 148 (147); unfortunately these drawings have not been preserved. 

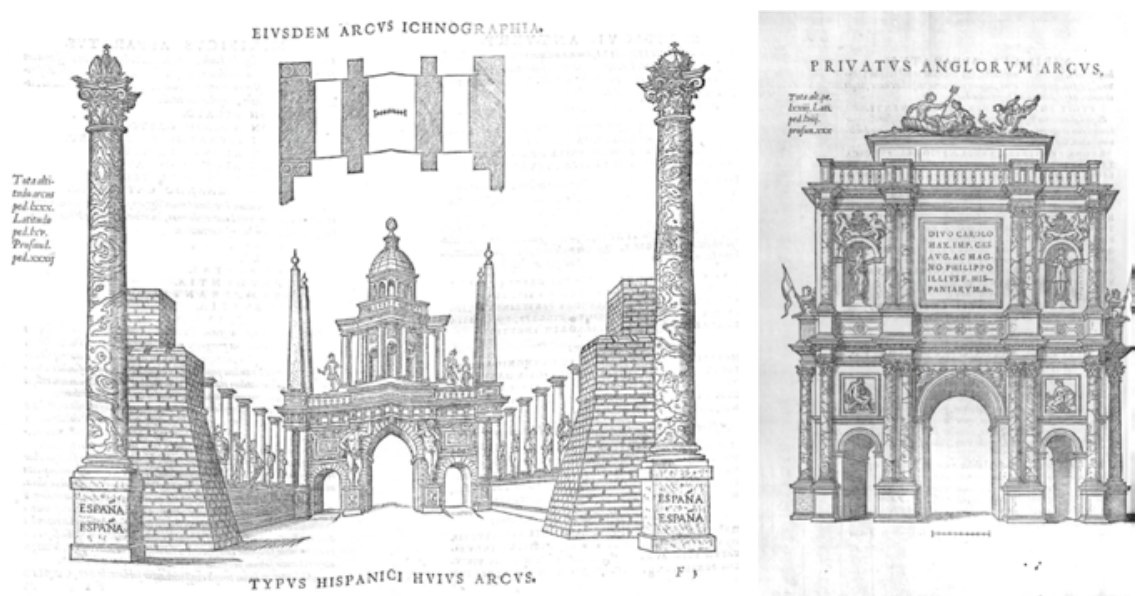

FIGURES 5.46-5.47 Ceremonial entry of Philip of Spain in Antwerp, 1549: triumphal arches of the Spanish and the Flemish merchants, woodcuts by Pieter Coecke van Aalst, from Cornelius Graphaeus, Spectaculorum in Susceptione Philippi Hispaniae Principis, Antwerp 1550.

new Vitruvian principles of architecture, as derived from Italian and French examples. ${ }^{63}$

\subsubsection{The Prince as Architect: Summing Up}

It was only natural that, like his cousin Philip II, in his own architectural ambitions Maximilian would be influenced primarily by the projects undertaken by his immediate peers. The most important of these, in order of precedence and importance, were his own relatives, the Spanish Habsburgs and the King of France; the latter was both a close family connection and his dynasty's biggest rival. Then there were the various princes of the Empire and in Italy, in the first place those with whom the Habsburgs had dynastic ties and/or close political connections, such as the Dukes of Mantua, Bavaria, Saxony, JülichCleves-Berg, and Andrea Doria. Finally the influence of noblemen, magnates and officials closely tied to the Habsburg interest should not be underestimated. These include, for instance, Jean de Hennin-Liétard, Count of Boussu, and the Granvelle family in the Netherlands; Bernard Cles, prince-bishop of Trent, and Gabriel Salamanca in Northern Italy and Austria, and the Fuggers in Southern Germany.

63 Discussed in detail and in their influence on Flemish architecture by Wouter Kuyper, The Triumphant Entry of Renaissance Architecture into the Netherlands (Kuyper 1994) and cf. Boogert 1998, p. 17 and note 22. 
Such examples entailed the building of large residential buildings in an advanced, correct and relatively sober, classical style, a style which was derived from the Italian, particularly Roman, architecture of the first decades of the sixteenth century. But such emulation did not always extend to stylistic detail. It may have been the procedure that served as an example, as much as any individual design. It is striking that the patrons commissioning the most advanced, avant-garde projects all employed artists that either were Italian or had studied in Italy: Charles v, Mary of Hungary and Jean de Hennin-Liétard all employed Jacques Du Broeucq; Count Henry iII of Nassau-Breda employed Tommaso Vincidor from Bologna, a pupil of Raphael; Maximilian van Egmond, Count of Buren and later Wilhelm v, Duke of Jülich, Cleves and Berg both employed Alessandro Pasqualini, also from Bologna, and Granvelle employed an as yet unidentified but certainly Italian or Italianate architect.

It should be noted that none of these architects were master masons, none of them were menial craftsmen: they all were painters or sculptors, sharing a common artistic and intellectual training, and therefore were capable of exchanging ideas and advice directly with their patrons. That is, they were architects more or less conforming to Vitruvius' ideal type of the architect as an intellectual.

Apart from Boussu, which was not yet finished when he saw it last, Maximilian could inspect the beneficial effect of employing such learned architects at least in one instance in great detail. This was in Jülich, where Maximilian twice visited his sister Maria and her husband Wilhelm v, Duke of Jülich-Cleves-Berg [Fig. 5.48], with whom Maximilian always maintained a good personal relationship. Under Duke Wilhelm's aegis the small fortified town was completely remodelled and fortified in the modern manner by Alessandro Pasqualini, who also designed the town hall and the church steeple.

Most imposing was the huge citadel Pasqualini added on one side of the town, within which he constructed a residential palace, realizing the archetype of the 'palazzo in fortezza' as proposed by Serlio [Figs. 5.49-5.53]. ${ }^{64}$

The actual palace is very reminiscent of Boussu both in choice of material and in lay-out, four wings around a courtyard lined with colonnades carrying galleries. The architectural detail, in particular of the chapel, but also of the staircases and door surrounds both inside and outside, is of an astonishing sophistication [Figs. 5.49, 5.52 and 5.53]. There can be no doubt that Maximilian was impressed by Jülich's fortifications and by the ducal residence, both

64 Maximilian visited Jülich twice in 1556, from 12-14 July and from 10-13 August (Holtzmann 1903, pp. 276-277 and 288-289); on the fortifications and the Residenzschloß at Jülich, a.o. Büren/Kupka 2005; on Pasqualini, Büren 1995. 

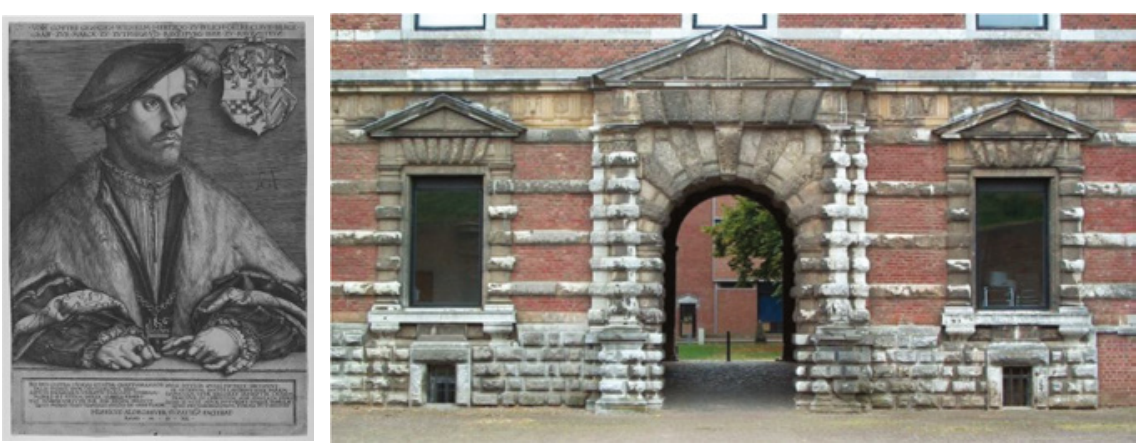

FIGURE 5.48 Heinrich Aldegrever, Wilhelm v, Duke of Jülich, Cleves and Berg, engraving, 1540.

FIGURE 5.49 Jülich, Ducal palace, rustic portal and window surrounds, ca 1550 .

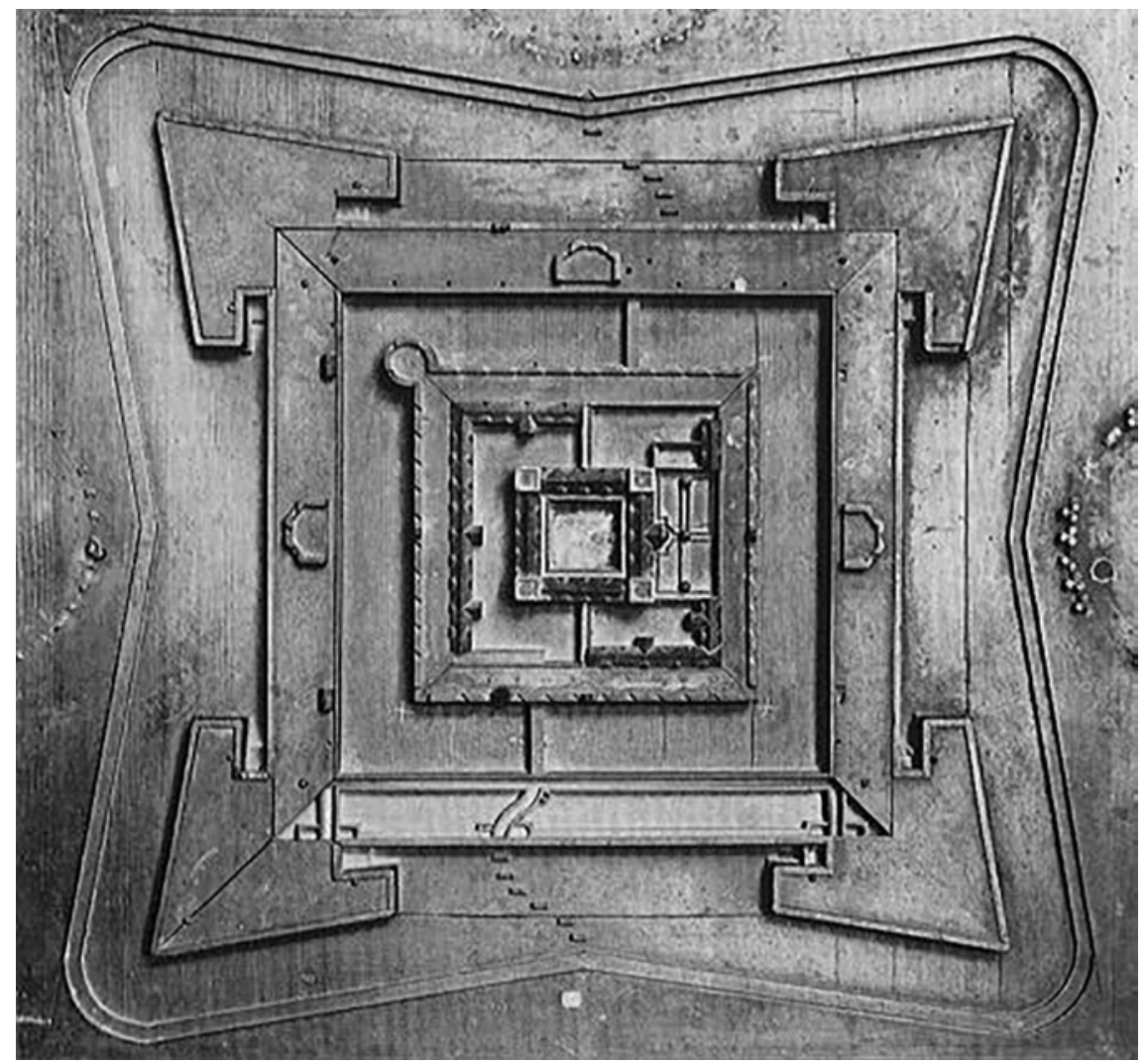

FIGURE 5.50 By or after Alessandro Pasqualini: the original model for the construction of the citadel at Jülich, ca 1547 . 

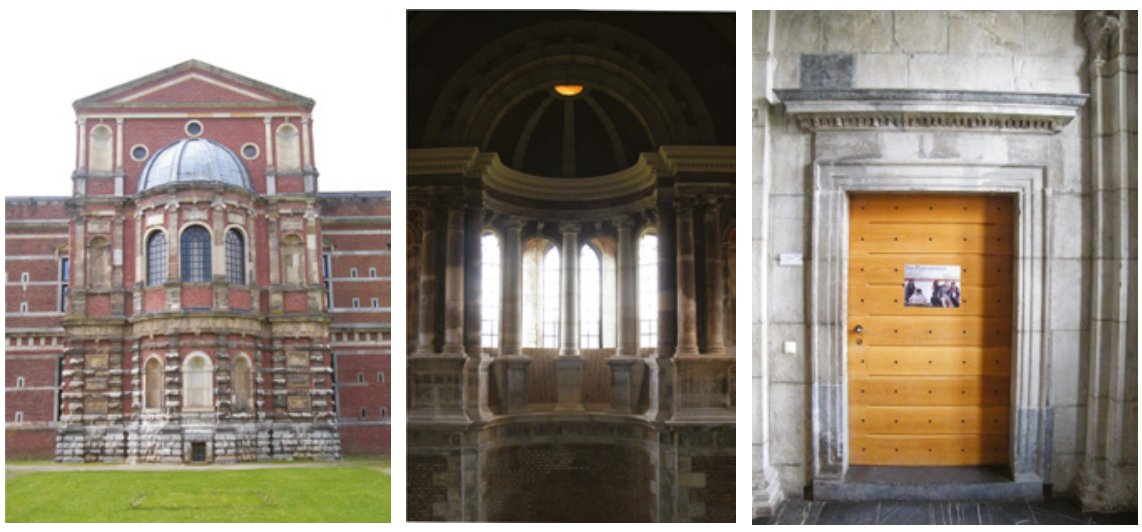

FIGURES 5.51-5.53 Jülich: exterior and interior of the chapel, and door surround in staircase hall, $1547-1556$.

examples of the most advanced and sophisticated design of the day. It is conceivable that he was given a guided tour by his brother in-law, or perhaps by Alessandro Pasqualini himself, who as Duke Wilhelm's principal engineer and architect had been responsible for their design and construction.

\section{3 'Adeste Musae': Maximilian's Hunting Lodge and Garden in the Prater}

Such experience cannot have failed to influence Maximilian, who had great aspirations in his youth and wished, as he had written to Hans Jakob Fugger from Spain, to leave some memorial of himself. ${ }^{65}$ Examples such as Jülich may have incited him to emulate his brother-in-law and tempted him to underline his status by commissioning projects of similar size or splendour. His material circumstances being limited, however, he must have realized that it was wiser to attempt to rival the sophistication of his cousins' and in-laws' enterprises, rather than such size and splendour.

\subsubsection{Hvězda and the Prater Lusthaus: The Type and Its Models}

Such emulation of foreign princes may have played a role when, at about the time of his second visit to Brussels, Maximilian built his hunting-lodge in the Prater and began laying out its gardens. But here emulation of his own younger brother was probably of greater importance: it can hardly be a coincidence

65 Cf. above, Ch. 5.2.1; and Fichtner 2001, pp. 22-23. 
that Maximilian and Ferdinand built their hunting lodges in Vienna and Prague at exactly the same time, in 1555 , and in a very similar situation. The location of the Grünes Lusthaus was indicated as 'Ad Puteum Cervinum, 'at the deer fountain', i.e. in a hunting preserve, while Hvězda was built in what was called a 'Tiergarten', likewise an animal and game preserve. Though except for its cruciform plan we do not know exactly what the Prater Lusthaus looked like-it was replaced in 1781-83 by the still existing pavilion designed by Isidore Canevale - it is clear that both hunting lodges are similar in conception and both were richly decorated. Most striking is perhaps that both were carefully documented at the time. The designs of Hvězda mentioned earlier were carefully copied in a set of presentation drawings [Figs. 5.22-5.24; 5.55] and the complex was described in a Latin poem by Vavřinec Špan ze Španova, Ferdinandopyrgum. Maximilian's Lusthaus was documented in a learned, Latin treatise by a Vienna lawyer and Greek scholar, Georg Tanner, illustrated by plans of its gardens by Bonifaz Wolmut [Figs. 5.54 and 5.65-5.69]. ${ }^{66}$
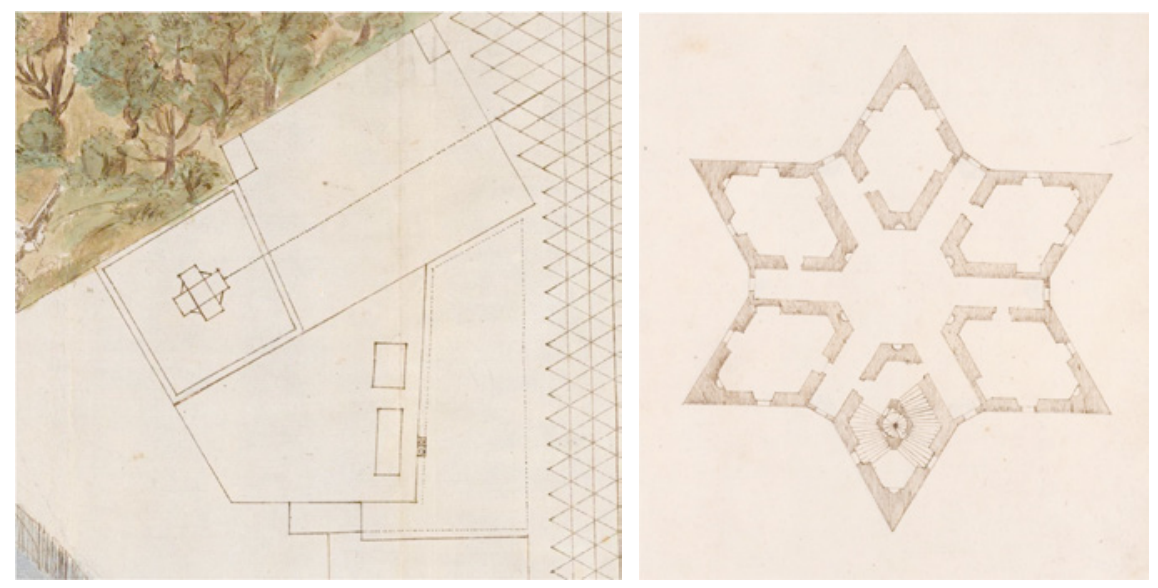

FIGURE 5.54 Plan of the Grünes Lusthaus, built 1555-57 for Maximilian ii in the Prater just outside Vienna; detail from the plan inserted in Georg Tanner's description (1557).

FIGURE 5.55 Plan of Hvězda, ground floor; presentation drawing by unknown Italian draughtsman after an autograph by Archduke Ferdinand, 1555 .

66 Tanner described the location of Maximilian's Lusthaus as 'ad Puteum cervinum', 'am Hirschbrunnen'. The drawings of Hvězda are in Vienna, öNB-Hs, Cod. min. 108; as is Špan's poem, Cod. 9902 (with a provenance from Ferdinand's library at Ambras); on Hvězda, see now Dobalová/ Hausenblasová / Muchka 2014; also Simons 2009, pp. 99-130, which supplies the earlier bibliography, and Dobalová 2009, pp.203-213; Tanner's description of the Prater hunting lodge: Brevis Et Dilucida Domini Dom. Maximiliani Inclyti Regis Bohemiae et Archiducis Austriae ec. Viennae Ad Danubii Ripas Et Diaetae Seu Amoenarii Ad Puteum 
All this suggest that the two houses were built in conscious emulation of one another. This corresponds with what we know of the personal rivalry between Maximilian - who was titular King of Bohemia and future Emperor, but was given little direct authority by his father - and his brother Ferdinand, who as regent for the Emperor actually governed his elder brother's kingdom. Such antagonism is not, however, necessary to explain their competition, which might just as well be interpreted as the friendly emulation of brothers enthusiastically engaging in a common hobby. Certainly their choice of unusual, centralized, geometrical ground plans for their country houses indicates that each was aware of what the other was doing, and they may well have discussed their experiments in their leisure hours.

Ivan Muchka has suggested that Hvězda was inspired by similarly unusual plans for palaces in the fourth of Pietro Cataneo's I primi quattro libri di architettura, which had come off the Aldine press in Venice only the year before [Figs. 5.56-5.57].67 In fact Cataneo actually describes his proposals as a sort of geometrical experiment:

[Ch. x:] It is a good thing to change sometimes from the ordinary buildings, by which often one obtains both the favour of the Republic or of one's patron, and the praise of the general public. For that reason I have shown various inventions that came to my mind. In the first place a plan in the form of a cross, derived from a square. And because its wings jut out on all sides, its rooms abound with beautiful light all over <...>

[Ch. XI:] In building houses or palaces, one can even go beyond rectangular forms, giving them a plan of hexagonal or octagonal form, or with even more angles and sides $\langle\ldots>$

[Ch. XI:] And not only is it sometimes convenient, for variation's sake, both in palaces and other buildings, to depart from rectangular figures; sometimes it is even necessary, better to conform to the whims of the patron, to depart from rectilinear figures, and to build the palace according to a circular or oval plan, or some other similar figure. ${ }^{68}$

Cervinum, Et Horti, Et Inprimis Veteris Quincuncis Descriptio, Authore Georgio Tannero (1558), in Vienna, ÖNB-HS, Cod. 8085; text printed in Chmel 1840-1841, 2, pp. 276-292. Cf. Lietzmann 1987, pp. 29-30; Almási 2009, pp. 115-119; Dobalová 2009, pp.213-218; Van Gelder 2011, pp.62-66.

67 Cataneo 1554; Muchka's suggestion in Rudolf II And Prague 1997, III.243; cf. Muchka 2002.

68 Cataneo 1554, f. 52v.-53v.: <Cap. X.>: 'Bella cosa è veramente il variare da gli edificii ordinarii: di che molte volte con lode universale se ne acquista la gratia della repubblica, 

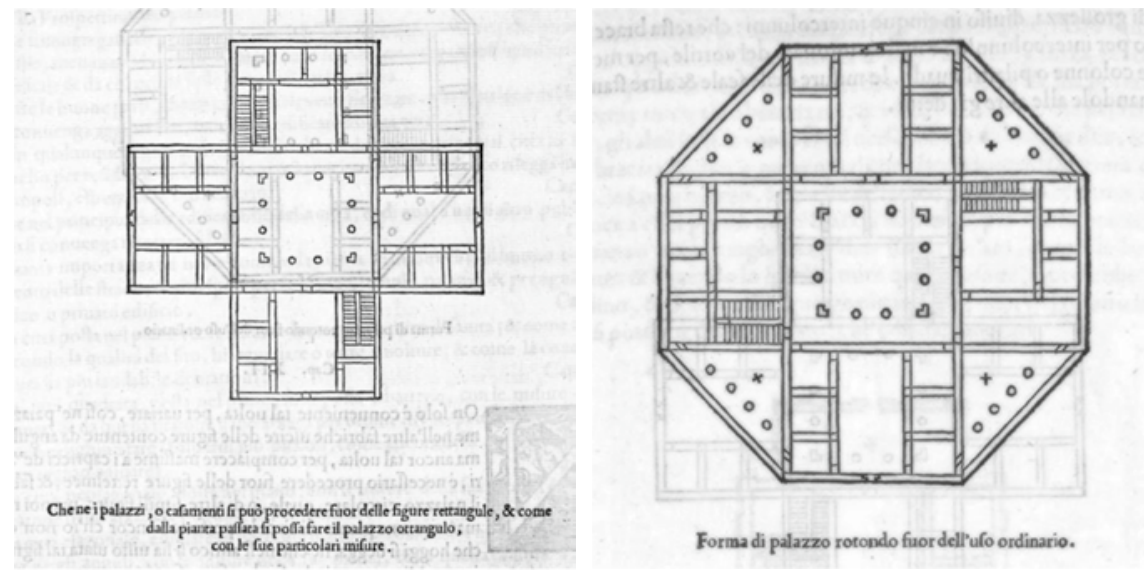

FIGURES 5.56-5.57 Pietro Cataneo, designs for centrally planned houses, from his I primi quattro libri dell'architettura, Venice 1554, Book iv, Ch. $\mathrm{x}$ and xi.

It should be noted, however, that such ideas were in the air: thus Giulio Romano, Sebastiano Serlio [Fig. 5.58] and Jacques Androuet du Cerceau all three experimented at the time with unusual plans, but it seems unlikely that these could have been available to the two Archdukes before the arrival of Jacopo Strada. ${ }^{69}$ On the other hand they may well have been aware of Antonio da Sangallo's as yet unfinished project for the Palazzo Farnese in Caprarola, which had been built for Ottavio and Alessandro Farnese, the husband and the brother-in-law of their cousin, Margaret of Austria, Duchess of Parma [Fig. 5.6o]. Sangallo's pentagonal plan derived from the new fortification techniques developed by fifteenth- and sixteenth-century engineers in response to

o del suo Signor. Sforzerommi per tanto di più inventioni, che mi vengono in mente <...> prima in pianta un palazzo à crociera, tratto dal quadro. et essendo intorno spiccato, abbonderanno per tutto le sue stanze di bellissimi lumi <...>'; <Cap. XI.> 'Potrassi ancor procedere ne i casamenti, o palazzi fuor delle figure rettangule, facendo il palazzo esagono, ottangulo, et di piu anguli et lati, di varie et diverse maniere, secondo il desiderio di chi edifica <...>'; <Cap. XII.> 'Non solo è conveniente tal volta, per variare, così ne' palazzi come nell'altre fabriche uscire delle figure contenute da anguli retti; ma ancor tal volta, per compiacere massime à i capricci de' Signori, è necessario procedere fuor delle figure rettelinee, et fabricare il palazzo circulare, ovale, o di altre simili figure <...>'

69 For instance Serlio in his Sesto Libro, which was never published, Pl. XIX, XXVIII, XXIX, XXXII and XL, and in his Settimo Libro, published by Strada only in 1575, a.o. Pl. XIII, XVIII and XXI; and Jacques Androuet du Cerceau, in his Livre d'architecture ... contenant les plans et dessaings de cinquante bastimens tous differens..., Paris, Benoît Prévôt, 1559, pl. XVI, XXVIII, XXXV, XLIII, XLIIII, XLVIII and XLIX. The rare examples of Giulio's architectural designs preserved in the Codex Chlumczansky in Prague, from Strada's holdings, included several centralized villas; cf. Giulio Romano 1987, pp. 516-519. 

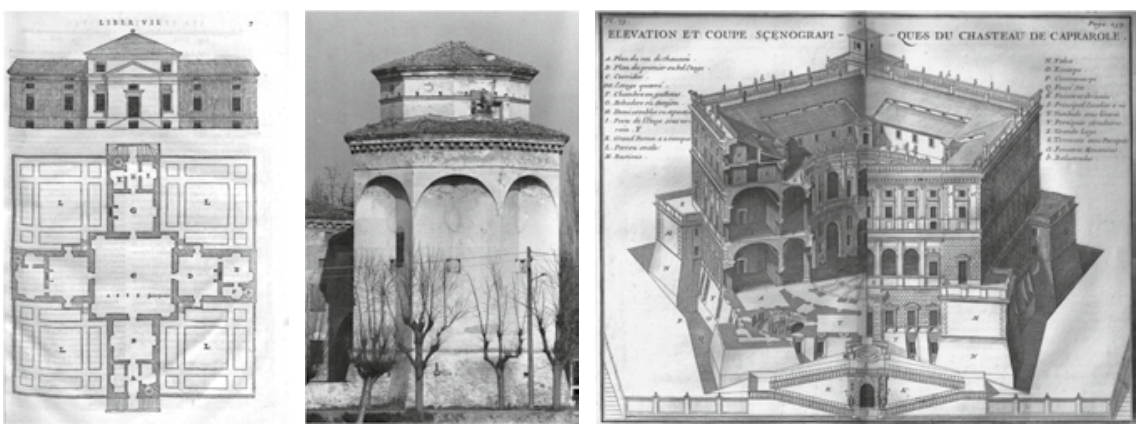

FIGURE 5.58 Sebastiano Serlio, Villa on a cruciform plan, from the Settimo Libro (1575).

FIGURE 5.59 Giulio Romano, Colombaio (dovecote) or torre stellare, Corte Castiglioni (Marcaria, Mantua, 1545-1549).

FIGURE 5.60 Antonio da Sangallo il Giovane, completed by Giacomo Barozzi da Vignola, Villa Farnese at Caprarola, begun 1529; in an engraving from Augustin-Charles d'Aviler, Cours d'Architecture, (1691).

the advent of artillery (which also takes up a substantial part of Cataneo's treatise)..$^{70}$ This is not, however, the case for other forms of centralized planning, where the 'esprit de géometrie' must have played the leading role.

A quite enigmatical example for Hvězda is the odd 'torre stellare', a pavilion or tower on a polygonal, star shaped plan, built in 1546 in the garden of the Corte Castiglioni in Marcaria near Mantua, for Camillo Castiglione, according to plans provided by Giulio Romano [Fig. 5.59]. The connection with Baldassare Castiglione, Camillo's father, is suggestive: Baldassare was the protector of both Raphael and Giulio Romano and spent his last years as Papal Nuncio at the court of Charles v. Because of his great interest in classical architecture, he has sometimes been credited with the design of Charles' palace in Granada. If Howard Burns' intuition that Giulio's designs for the torre stellare harked back to ideas of Baldassare himself is correct, that would have added to their status in Mantua. As a brand new example of gracious living its reputation could have reached Ferdinand through his sister Catherine, widow of Duke Francesco III. Moreover there is a good chance that his brother, Maximilian, had actually seen the tower when it was just completed, since on his trips to and from Spain he could hardly have passed the Villa, which is situated on the

70 The small but exquisite hunting lodge at Maulnes in Burgundy, the best French parallel to Hvězda, was built 1566-1573, for Antoine de Crussol, duc d'Uzès, and his wife Louise de Clermont-Tonnerre, sister of Serlio's patron at Ancy-le-Franc. Its pentagonal plan, however, derives from the Caprarola prototype. 
road from Mantua to Cremona, without accepting Camillo Castiglione's invitation to break his journey at least on one of these occasions. ${ }^{71}$

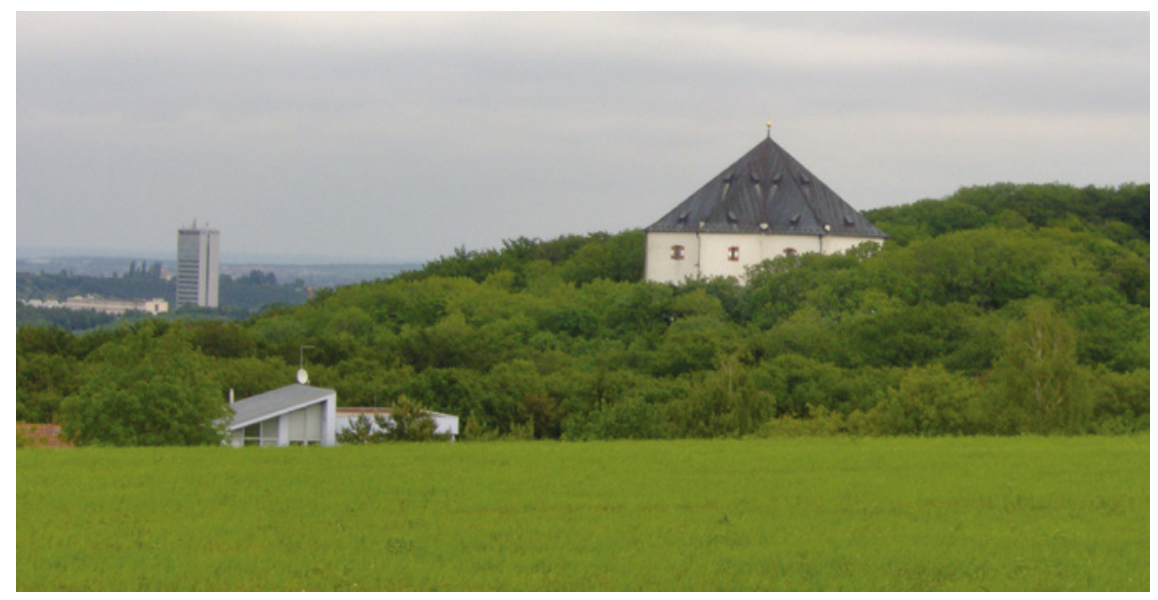

FIGURE 5.61 Prague, hunting-lodge Hvězda (Schloss Stern), built $1555^{-1560}$ for Archduke Ferdinand II of Tirol, as seen from the White Mountain.

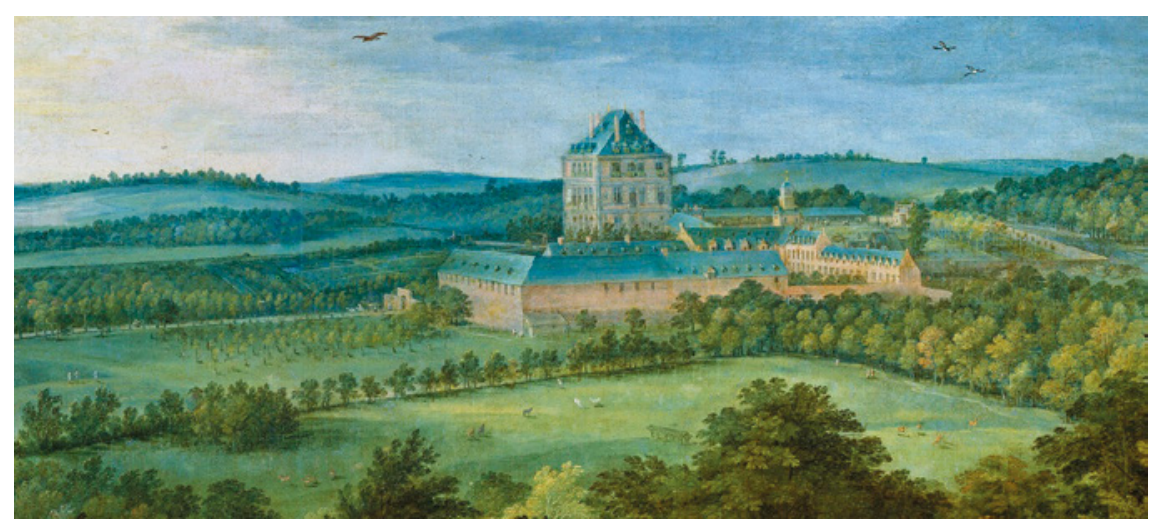

FIGURE 5.62 The Château de Mariemont, detail from Jan Brueghel the Elder, The Archdukes Ferdinand and Isabella hunting at Mariemont, ca 1611; Madrid, Museo del Prado.

71 Castiglione spent the last years of his life as Papal Nuncio at the Spanish court-he died of the plague at Toledo in 1529 - where he was very highly regarded. In view of his standing it is not inconceivable that (copies of) some of his sketches were still circulating at the Imperial court. But Ferdinand might also have had access to Giulio's project by virtue of the close connections between the Austrian Habsburgs and the Gonzaga: his sister Catherine was the widow of Duke Francesco III ( $\dagger$ 1550), and a second sister, Eleanor, would marry Francesco's successor Guglielmo in 1561 . The torre stellare did not function as a hunting lodge and belvedere (it had few, very small windows), but as a private retreat: 
However, the immediate model — or at least the inspiration — for the houses of both archdukes was the hunting lodge built in 1546-1549 by their aunt, the dowager Queen Mary of Hungary and Regent of the Netherlands for her brother Charles v, at her domain Mariemont a few miles from her country palace at Binche in Hainaut. It was designed by her architect Jacques du Broeucq, whom we have already met as the designer of Boussu, and who also remodelled Mary's principal residence at Binche and created its huge banqueting hall. Mariemont consisted of a square box of three stories surrounded by a few lower annexes, set in the middle of an ample hunting preserve [Fig. 5.62]. ${ }^{72}$

Such retreats may have been a family hobby: some years later Charles v himself had a small house built, again designed by Du Broeucq, in the 'Warande', the animal preserve close to his palace at Brussels, for which a three-dimensional model of Chambord, in the possession of Cardinal Granvelle, appears to have been consulted..$^{73}$ Both Archdukes spent periods at the court of Charles and Mary both in Brussels and elsewhere, and must have heard about or even seen something of these projects.
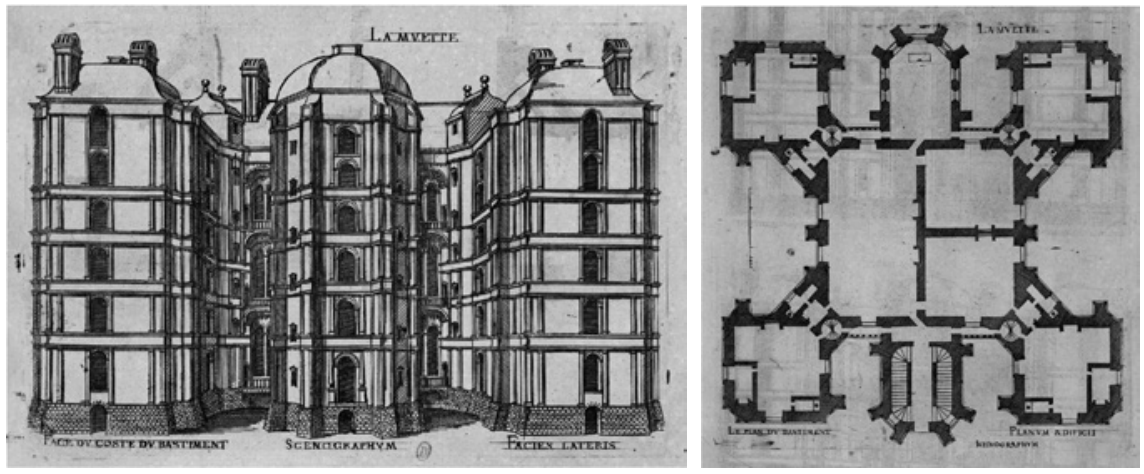

FIGURES 5.63-5.64 Château de la Muette, Saint-Germain-en-Laye, 1542-1549, elevation and plan from Jacques Androuet du Cerceau, Les plus excellents bastiments de France, I, 1576.

it was only accessible directly from the patron's apartment through a bridge on the upper level connecting it with the main building, and its lower floor seems to have functioned as 'stufa', or heated bathroom. The top floor, on the other hand, functioned as the traditional colombaia or dovecote of an Italian country house; cf. Howard Burns and Pier Nicola Pagliara in Giulio Romano 1987, pp. 526-527.

72 It was destroyed by the French in 1554, but restored 1555-1559 under Du Broeucq's direction, and later extended for the Archdukes Albrecht and Isabella. Jan ('Velvet') Brueghel made several paintings of it: in conjunction with the detailed accounts, these provide sufficient information for a reconstruction of the original hunting lodge, given in De Jonge 2005 .

Boogert 1998, pp. 6o, 141, 161 . 
If they knew about Chambord, which had been built for Francis I, king of Franceand husband of theirauntEleanor, theymay haveknown aboutLaMuette, another project of Francis I that provides an interesting parallel to Mariemont and the hunting-lodges in Prague and Vienna [Figs. 5.63-5.64]. La Muette was a hunting lodge built between 1542 and 1549 in the park of Saint-Germain-en-Laye, and its very name implies its function as a retreat from the pressures at court. But it also served as a belvedere from which (theladies of?) the court could follow the hunt in the surrounding wood at leisure. Both functions are explicitly referred to in the relevant entry in Du Cerceau's Les plus excellents bastiments de France:

The late François de Valois, King of France, chose a site close to a small marsh where the red deer, exhausted from the chase, hid themselves, and he had this house built here, to have the pleasure of seeing how they were done to death; and he called it La Muette, for being in a secret and remote place, and surrounded by forest on all sides. ${ }^{74}$

In his comment David Thomson points out that 'the form of hunting lodges or pleasure houses was always the object of daring experiments', and that is certainly the case at La Muette: like Mariemont it is a tall block-like pavilion in the midst of a wood, but it is built on a quite audacious centralized plan, consisting of a square tower with smaller, almost detached towers or pavilions on each corner, and a chapel and staircase tower tacked onto two of its facades. Such parallels leave little doubt about the function of the Archdukes' two similar lodges: both were built likewise in wooded country rich in big game, in particular deer. They offered a convenient place to meet for the hunt, to cater for and enjoy the huntsmen's picnic, and to provide shelter and entertainment for participants and invited onlookers in case of adverse.$^{75}$

\subsubsection{The Function of the Prater Lusthaus and Hvězda}

Such outings, providing small-scale entertainment for a select group of close friends or important guests may also have been organized independently from

74 Androuet du Cerceau/ Thomson 1988, p. 103: 'Feu François de Valois, Roy de France <...> choisit un endroit [in the forest of St Germain] pres d'un petit marescage $<\ldots>$ où les bestes rousses lassees du travail de la chasse se retiroyent: et y feit dresser ceste maison, pour avoir le plaisir de veoir la fin d'icelles, et la nomma la Muette, comme lieu secret, \& separé, \& fermé de bois de tous costez <...>'. and ibid., p. 104.

75 ibid. p. 108. François I built a similar hunting lodge at Challuau, near Fontainebleau, for his mistress, the Duchesse d'Étampes, according to Du Cerceau again because 'qu'audict bois prochain y avoit grande quantité de cerfs', ibid. p. 291. Girouard 1978 cites English instances of hunting lodges that conform to the pattern, often located in special game preserves, from the fifteenth and early sixteenth (pp. $76-78$ ) and the late sixteenth and early seventeenth centuries (pp. 106-108). 
a hunting event. In England a similar function was fulfilled by small lodges that were confusingly known as 'banqueting houses.' ${ }^{76}$ Both as hunting lodges and as 'banqueting houses' Hvězda and the Prater Lusthaus played a role within the representation of the two archdukes, and perhaps of the Emperor himself. This is obvious from the fact alone that both were sumptuously decorated: Hvězda with the still existent elegant stucco decorations, the Prater Lusthaus with stucchi, painting and precious marble:

Two years ago King Maximilian had constructed at magnificent expense a truly regal house, filled with ample rooms and fountains inlaid in various marbles and richly decorated with most elegant painting in gold, silver and other vivid colours, in the midst of a vast or rather immense area filled with poplars and oak trees of unusual size. ${ }^{77}$

But they provided the informal side of the necessary representation, geared to pleasure and otium, rather than formal representation of state, which concentrated on pomp and magnificence. Madelon Simons therefore rightly questions the role of Hvězda as an explicit 'theatre of representation'. Occasionally Hvězda may well have played a role in official representation, but rather than a principal motivation for its construction, that was a coincidence, a corollary of its more personal, private function. Like La Muette, the English lodges and the Torre stellare of the Corte Castiglione, Hvězda and the Grünes Lusthaus offered their patrons a private retreat from the court, used for private study and contemplation, for physical exercise, and for private entertainment. A sort of weekend home used to recuperate from the pressure of affairs and to escape from the attentions of obsequious courtiers and importunate suitors. ${ }^{78}$ In his description of the Prater Lusthaus Georg Tanner explicitly formulates this combined function. Its function as a hunting lodge is clear from the description of the woods which encircle the house on three sides,

76 Girouard 1978, pp. 104-108. These also often showed eccentric forms; Girouard's color plate IX illustrates a triangular lodge dating from 1595: an ancestor of the eighteenthcentury 'follies'.

77 Chmel 1840-1841, 2, p. 282: 'Ante biennium clementissimus Rex Maximilianus magnificis sumptibus regiam plane domum magna coenaculorum et puteorum marmore incrustatorum varietate, elegantissimis picturis, auro argento, aliisque vivis coloribus ornatissimam, in ingenti ac fere immenso campo inusitatae magnitudinis populis et quercubus refertissimo extrui curavit'.

78 Maximilian repeatedly used to disappear from Vienna for this purpose, for instance when he kindly but firmly dissuaded the Papal Nuncio, Stanislas Hosius, to follow him into the country. Hunting lodges such as Louis XIV's Marly (ca. 1679-1684), Clemenswerth built for Clemens August, Elector of Cologne (ca 1737-1747) fit into this tradition, though Juvara's 
$<\ldots>$ from where the deer come down all the way to the very lodge, and almost obtrude themselves to $<$ the huntsmen's $>$ nets, spears and bullets $<\ldots>$.

a passage which seems to prefigure Du Cerceau's comment on La Muette cited above. ${ }^{9}$ Earlier, Tanner had explained how this 'Royal Forest' was easily reached from town both on horseback and by boat, and continued:

Because this place, dedicated to the hunt and the royal pleasure, likewise is most suitable for all convenient sorts of honest physical exercise that maintain good health, His Royal Roman Majesty [= Ferdinand I] often uses to come here to refresh his soul, fatigued by his heavy cares, and to recreate himself without undesired disturbance. ${ }^{80}$

The passage illustrates how the Lusthaus, representing an uncontroversial common interest, served as a bond between Maximilian and his widowed father, allowing him to express the respect and love he felt for him by offering his hospitality, and giving Ferdinand a chance to show his appreciation of his son's project. It thus helped them to maintain some personal contact at a time when their conflict over Maximilian's attitude in religious matters was deepening. But Maximilian himself also used it for private contemplation, at least that must be why its garden included a 'iucundissimus Labyrinthus' consisting of hedges of fragrant plants such as myrtle and laurel, in the midst of which could be found 'tria amoenissima cubicula', three most pleasant chambers constructed of hedges of evergreen shrubs, keeping out the sun, and therefore 'perfectly

immense Palazzina della Caccia at Stupinigi, built 1727-1731 for Vittorio Amedeo II of Savoy, perhaps less so.

79 Georg Tanner, Brevis et dilucida Domini Do. Maximiliani inclyti regis Bohemiae et Archiducis Austriae etc. Viennae ad Danubii ripas et diaetae seu amoenarii ad Puteum Cervinum, et horti, et inprimis veteris quincuncis descriptio, Vienna, ÖNB-HS, Cod. 8085; description and long excerpts in Chmel 1840-1841, 2, pp. 276-292; p. 284: 'Unde cervi ad ipsam Diaetam usque prodeunt, et se ipsos telis, venabulis et Bombardiis quasi obiiciunt....' The larger hunting-lodge at Augustusburg near Chemnitz, constructed 1568-1572 for Elector August of Saxony, demonstrates this function clearly: even today the forest comes up to walls of the castle, which was surrounded by a hanging gallery at roof level, allowing its owner and his guests not only to see, but possibly also to shoot the deer driven under the walls by beaters on the ground.

8o Tanner, Brevis et dilucida <... > diaetae descriptio, as cited in Chmel 1840-1841, 2, p. 283 : 'Quare cum hic locus Venationi tanquam Regiae voluptati, adeoque omnibus honestissimorum exercitiorum bonae valetudini tuendae convenientissimorum generibus sit aptissimus, Romana Regia Maiestas animum gravissimis curia defessum ibi plerunque reficere, et sine interpellatoribus oblectare solet'. 
adapted for the King's recreation and profound reflections, in short for every honest and civilized study' ${ }^{81}$

The personal nature of the Grünes Lusthaus when compared with most of Maximilian's other commissions, coupled to Georg Tanner's manuscript explaining some of its guiding ideas, makes it valuable in an attempt to come a little closer to Maximilian's attitude to architecture and to cultural patronage in general. Tanner's manuscript, Brief and explanatory description of King Maximilian of Bohemia's lodge or pleasure house at the Hirschbrunnen, its gardens and especially of the ancient quincunx was dedicated to Maximilian in May $1557 .{ }^{82}$ It was written after a visit to the Prater when the complex had already been realized, and it served in part as an in memoriam for his host on that occasion, the Imperial Councillor Sebastian Huetstocker, who had been

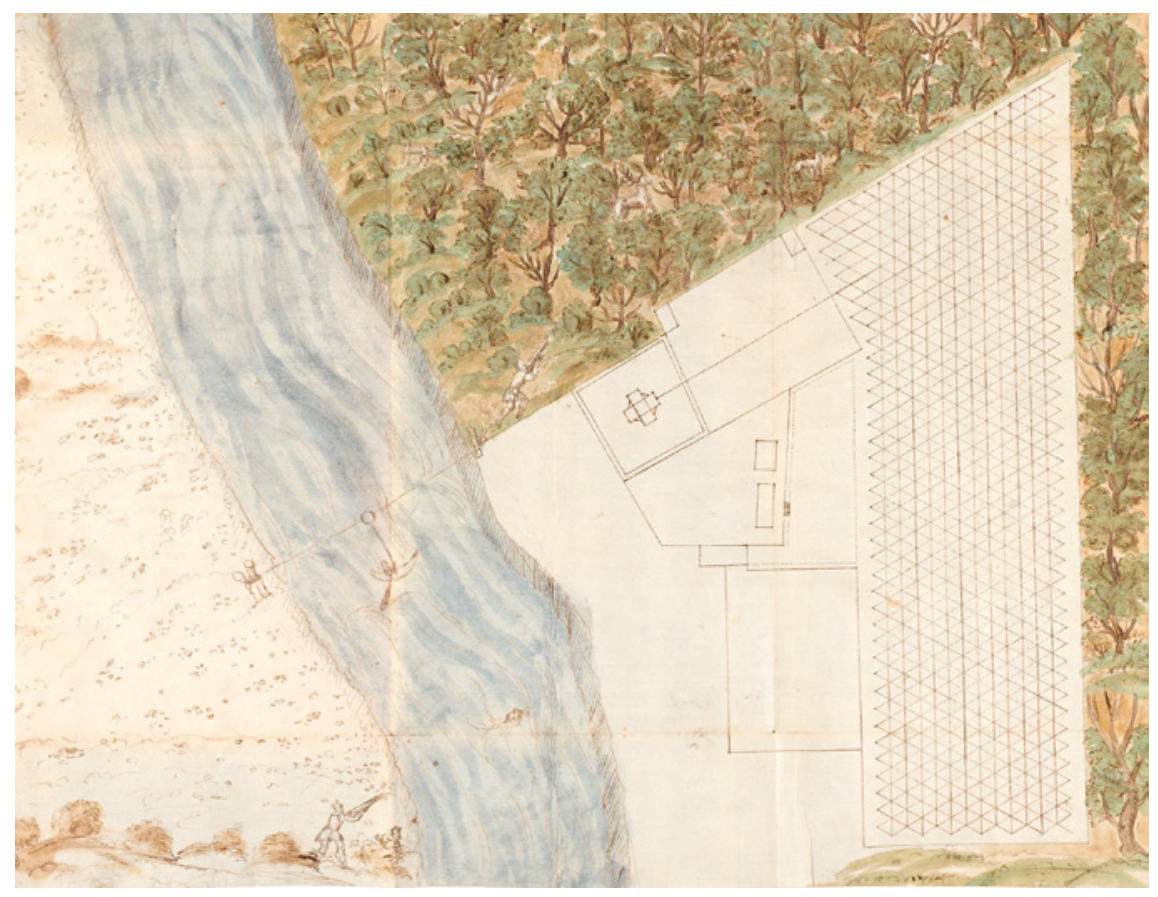

FIGURE 5.65 Bonifaz Wolmut, plan of the Grünes Lusthaus, built 1555 for Maximilian II, and the adjoining garden and orchard on the Prater island laid out $155^{6-57}$, from Georg Tanner's description (1557).

81 Tanner, Brevis et dilucida $<$... > diaetae descriptio, as cited in Chmel 1840-1841, 2, p. 286: 'Sunt et in eodem ordine [= the labyrinth] Tria amoenissima cubicula, opaca et frondibus fere perpetuo virentia, pergulis camerariis, una cum labruscis (Unde Omphacion seu Agresta conficitur) eas ambientibus, ut solis ardoribus minus infestari possit. Regiae quieti et arduis considerationibus, omnibus denique musis et honestissimis studiis aptissima <...>

82 Tanner, Brevis et dilucida $<$...> diaetae descriptio, ms. cited above; cf. Rudolf 1995, pp. 179-181; Almási 2009, pp. 115-119. 

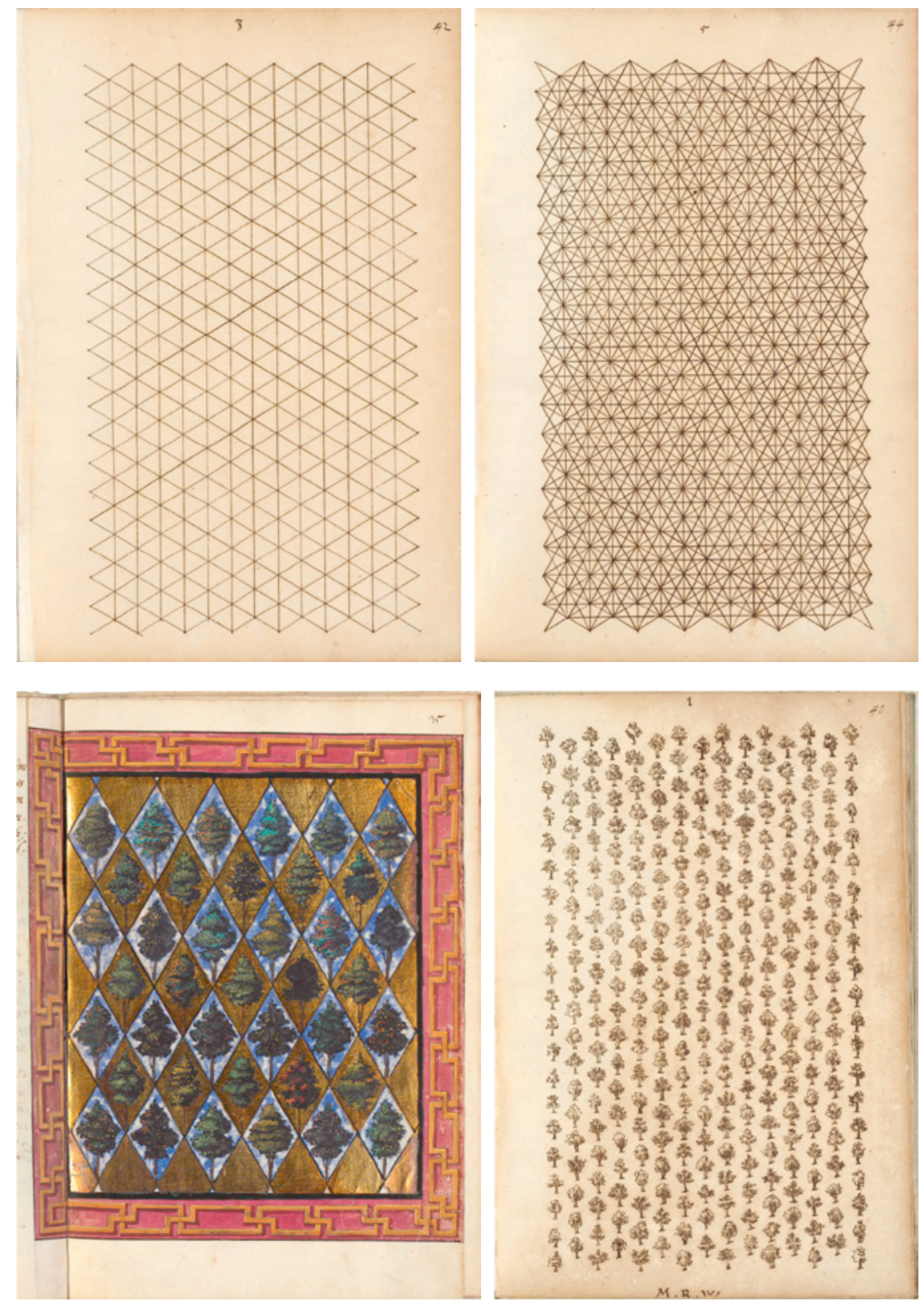

FIGURES 5.66-5.69 Bonifaz Wolmut, two geometrical schemes for a quincunx pattern and designs of an orchard planted according to the quincunx scheme, illustrations from Georg Tanner's description of Maximilian II's Grünes Lusthaus. 
responsible for some of its features and their execution. But it also served to publicize Tanner's own wide erudition, so his interpretations cannot automatically be assumed to coincide always with Maximilian's intentions. Nevertheless it is likely that Tanner's remarks complement and refine, rather than conflict with the King's own ideas; at the very least they represent ideas current in his immediate circle.

\subsubsection{Maximilian's Personal Participation}

After the fulsome dedicatory epistle, the actual treatise opens with Tanner's paraphrase of a passage from Xenophon's Economist, describing how the great Persian King Cyrus showed Lysander, a Greek envoy, his garden or 'Paradise' at Sardis, and stressing how this wonderful garden full of fragrant shrubs and regularly placed trees was designed and measured out in person by Cyrus himself, who had actually planted many of the trees with his own hands. ${ }^{83}$ Later in the text Tanner extends the parallel implied between the Sardis 'Paradise' and the Vienna Prater to include Maximilian's personal participation, when he describes how the King, on 21 May 1556, himself stretched a string from the central window of the Lusthaus, and began setting out the limits of the planned orchards and fixing the spots of the individual trees, some of which he planted himself. ${ }^{84}$ This confirms Crato's assertion in his funeral oration for Maximilian cited above.

If Maximilian took the trouble to execute the plans in person, it is also possible that he was chiefly responsible for the actual planning or designing that must have preceded it. If so, he must have been assisted by a professional who worked out the calculations and transformed his sketches into definitive plans: the obvious candidate is Bonifaz Wolmut, who shared the humanist interest and expertise necessary to understand the King's ambitions, and who provided the illustrations for Tanner's manuscript [Figs. 5.65-5.69]..$^{85}$ Tanner strongly emphasizes the fact that the garden was laid out and that the trees were planted

83 ibidem, pp. 281-282; Xenophon, The Economist, IV; cf. the English translation by H.G. Dakyns: 'Lysander, it seems, had gone with presents sent by the Allies to Cyrus, who entertained him, and amongst other marks of courtesy showed him his 'Paradise' at Sardis. (16) Lysander was astonished at the beauty of the trees within, all planted (17) at equal intervals, the long straight rows of waving branches, the perfect regularity, the rectangular (18) symmetry of the whole, and the many sweet scents which hung about them as they paced the park. In admiration he exclaimed to Cyrus: 'All this beauty is marvellous enough, but what astonishes me still more is the talent of the artificer who mapped out and arranged for you the several parts of this fair scene'. (19) Cyrus was pleased by the remark, and said: 'Know then, Lysander, it is I who measured and arranged it all. Some of the trees', he added, 'I planted with my own hands'. Tanner, whose description is more extensive, may have used a later paraphrase or translation, perhaps Cicero's?

84 Chmel 1840-1841, 2, pp. 263-264.

85 ibidem, p. 289, attributes the general plan [Fig. 5.65] to Wolmut; the drawing of the orchard is signed MBW (for '<de> manu Bonifacii Wolmut'?). 
according to a specific geometrical scheme or figure, the quincunx. This is the configuration of five points within a square or rectangle, four at the corners and one in the centre, for instance the way the number five is disposed on a die or a playing card. It is a scheme perfectly suited to repetitive applications such as the planting of a wood or orchard [Fig. 5.66-5.69]. ${ }^{86}$

Tanner strongly emphasizes the geometrical and arithmetical aspect of the application of the quincunx to the garden, supplying all the measurements of the lay-out. It was probably no coincidence that it was Paul Fabricius, the court-mathematician, who provided the laudatory 'Epigramma', in fact a 22line ode, preceding Tanner's text:

Struxit et ad ripam spatiosum fluminis

$\backslash$ hortum

In quo QUINCUNCIS culta figura patet.

Solus ibi QUINCVNX disponit in ordine

I plantas,

Ponit et exiguo plura vireta loco. 87
He also constructed a spacious garden at the

\river's bank

In which the elegant figure of the QUINCUNX

I stands out.

There the QUINCUNX alone arranges the

I plants in order

And adds green pavilions in a small space.

This geometrical concern provides a parallel to Hvězda, where the house itself was designed using a geometrical figure based on the number six. Surely it is no coincidence that Ferdinand's six-pointed star and Maximilian's quincunx are both celebrated in poetic epigraphs emphasizing their patrons' personal geometrical involvement? Moreover a case might be made that the ground plan of the Lusthaus itself foreshadowed the lay-out of the orchards in the quincunx system, for a cross inscribed in a square is itself an example of the quincunx. A plan such as is suggested by Cataneo [Fig. 5.56], where the central space is a courtyard or atrium - that is an open space corresponding to the four open spaces in the corners-makes that particularly clear.

The choice of the quincunx for the lay-out of Maximilian's orchards was not, however, his original invention. It had been suggested to him by Sebastian Huetstocker, who in his turn had been reminded of it by local humanists such as Joannes Ludovicus Brassicanus and the chancellor of Lower Austria, Marcus Beck von Leopoldsdorf. ${ }^{88}$ As true humanists they had found the idea in

86 The continuous appeal to learned gardeners of Cyrus' garden and its quincunx pattern is exemplified by Sir Thomas Browne's hermetic treatise, The Garden of Cyrus, or The Quincuncial Lozenge, or Network Plantations of the Ancients, naturally, artificially, mystically considered, London 1658 .

87 Chmel 1840-1841, p. 276. I am grateful to Bernhard Schirg for help with the translation.

88 ibidem, p. 263: 'Hac foecondissima plantandarum arborum ratione ab ipso Huetstokero Regi Maximiliano eposita, tantopere Rex delectatus est, ut citra moram huiusmiodiu Quincuncialem Seriem ex arboribus sylvestribus per universum Hortum ichoari iusserit'. 
classical literature, and a large part of Tanner's treatise is dedicated to listing and quoting the classical sources on the lay-out and management of gardens, and in particular the quincunx, including Columella's De Re Rustica, Virgil's Georgica and Pliny's Historia Naturalis. These are mostly practical treatises on agriculture and husbandry, and Tanner actually stresses the functional use of Maximilian's garden, which included not only orchards but also herbal and kitchen gardens. Next to its recreational and representative functions, the domain was useful in providing the Vienna court with the game, the vegetables and the fruits-often exclusive, exotic ones- that it needed in large quantities. ${ }^{89}$ This practical aspect also applies to the quincunx, which is praised not merely for its geometrical perfection, but also because it gave the individual trees more space and better protected them against adverse weather conditions. ${ }^{90}$

Of course we do not know whether Maximilian himself had studied all of these texts. When Tanner was asked to prepare the description of the garden, he may have begun collecting such classical instances to vindicate the King's project ex post facto. But it seems more likely that he merely added to the arguments and ideas that had inspired the design of Maximilian's garden, and that the King had read at least some of these texts himself-though possibly he limited himself to the relevant passages pointed out to him by advisors such as Huetstocker. That he should have read such texts is not really odd, in view of his intelligence, his gift for languages and his well documented personal interest in gardening. It could moreover be justified because such texts often made part of, or complemented more general arguments of domestic economy, and were therefore of immediate practical use for an efficient administration of his patrimony, and, by analogy, also for the proper government of his states. That at least is the point made by Tanner's opening quotation, taken from a treatise entitled 'The Economist' and describing the gardening activities of a prince who is explicitly presented as the ideal ruler. Like his Cyropedeia, Xenophon's Economist was perfectly suitable for the education of a prince, and in some version it may already have been among the reading material assigned to Maximilian by his teachers long before he ever thought of building or of gardening.

Yet the general tenor of Tanner's description of the King's 'amoenissimus hortus' is to sing the praises of the many animals that inhabited its groves, the many species of birds whose sweet music filled the air, the flowers that bejewelled its meadows:

89 ibidem, p. 286, for instance: 'Is prope sepem circum circa oblonga et amoenissima ambulatione vitbus odoratis, et iis quiem laetissimis consitus in quotidianum Culinae usum, ut salubres (ut Virgilius inquit) corpori praebat cibos, prudenter destinatus est'.

ibidem, p. 284. 
Flores nitescunt discolore gramine,

Pinguntque terras gemmeis honoribus

$<\ldots>$

Aves canoros garrulae fundunt sonos, Et semper aures cantibus mulcent suis.
Behold, with lively hue,

fair flowers that shine so bright:

With riches, like the orient gems,

they paint the mould in sight.

$<\ldots>$

Birds chatter, and some chirp,

and some sweet tunes do yield:

All mirthfull, with their songs so blithe,

they make both air and field.

Much of his text reads as an extended paraphrase of a (pseudo-)Virgilian ode, De laudibus hortuli, from which he took these two quotations, and it is this poetic, idyllic quality that is most striking in his description of Maximilian's garden. ${ }^{91}$ Though we will never know for sure, it is quite possible that this poetic aspect of Tanner's text best expresses the character of Maximilian's fascination with nature, and so explains his lifelong addiction to gardening. Tanner's references to legendary precedents, such as the Gardens of Alcinous and the Garden of the Hesperides, indicate that this fascination was fed with other literary concepts and conceits. Surely it is no coincidence that the Virgilian ode he quotes opens with an exhortation to the Muses:

ADESTE MUSAE, maximi proles Jovis! The issue of great Joue,

draw nearyou Muses nine:

Laudes feracis praedicemus hortuli.

Help us to praise the blisfull plott

of garden ground so fine.

Certainly Maximilian shared this fascination for a 'learned' or a 'poetic' sort of gardening with many of his contemporaries, witness not only the many gardens laid out in the sixteenth century, but also the importance of gardens and pastoral nature in the literature of the period. In fact one of the most famous ones, The Countess of Pembroke's Arcadia by Sir Philip Sidney, in its turn seems

91 At least, Tanner - and probably Maximilian himself - thought it was Virgil (Chmel 18401841, 2, p. 282), whereas nowadays it is ascribed to Asmenius (ca $400 \mathrm{AD}$ ) or Ausonius (ca $310-$ ca $394 \mathrm{AD}$ ). The full poem, Adeste Musae, maximi proles Iouis is given in H.W. Garrod, The Oxford book of Latin verse; from the earliest fragments to the end of the 5 th century A.D., Oxford 1912, pp. 404-405. It was later set to music by Rudolf II's court composer Jacobus Gallus (or Handl). The contemporary translation is by Nicholas Grimald (1519-1562), quoted from The Oxford Anthology of English Literature, I: The Middle Ages through the Eighteenth Century, Oxford 1973, p. 610 (which oddly does not identify its precise Latin source). 
to have been inspired by Maximilian's gardens in Vienna, just as it borrowed the concept of a star-shaped lodge from Ferdinand's Hvězda in Prague. ${ }^{92}$

\subsubsection{Conclusion}

If it can be assumed that Tanner attempted to please his patron, his description of the 'Diaeta ad Puteum Cervinum' reflects Maximilian's preferences at least to some extent, and we may conclude that by the time Tanner wrote, the garden loomed much larger in the King's thought than the Lusthaus inside it. Rather than its architecture, he preferred to have documented the garden that surrounded it, its layout, its planting and its animal inhabitants; this in marked contrast to his brother Ferdinand, who had commissioned carefully drawn detailed presentations drawings of his Prague hunting-lodge. This relative preference for gardening over building seems to be in character with what we know of Maximilian's interests later in his career. ${ }^{93}$ Yet one should be wary to conclude that he did not particularly care for architecture: after all he had begun his project by constructing the Lusthaus, of a similar size and on a hardly less unusual plan as that of his brother in Prague, and he had it quite sumptuously decorated. ${ }^{94}$ Moreover, when a decade later he began planning another, much

92 Philip Sidney, The Countess of Pembroke's Arcadia, Ch. 13: 'And thus with some other wordes of entertaining, was my staying concluded, and I led among them to the lodge; truely a place for pleasantnes, not vnfitte to flatter solitarinesse; for it being set vpon such an vnsensible rising of the ground, as you are come to a prety height before almost you perceiue that you ascend, it giues the eye lordship ouer a good large circuit, which according to the nature of the country, being diuersified betwene hills and dales, woods and playnes, one place more cleere, and the other more darksome, it seemes a pleasant picture of nature, with louely lightsomnes and artificiall shadowes. The Lodge is of a yellow stone, built in the forme of a starre; hauing round about a garden framed into like points: and beyond the garden, ridings cut out, each aunswering the Angles of the Lodge: at the end of one of them is the other smaller Lodge, but of like fashion; where the gratious Pamela liueth: so that the Lodge seemeth not vnlike a faire Comete, whose taile stretcheth it selfe to a starre of lesse greatnes'. Sidney stayed in Vienna twice, in 1574 and in 1577, when he served as Elizabeth's ambassador congratulating Rudolf II on his accession. On both occasions he also visited Prague. Cf. Girouard 1978, p. 8, who does not, and Skretkowicz, 1982 who does establish the connection with Hvězda (p. 180): 'Hvězda does, however, appear to lie behind Basilius's lodge in the New Arcadia and, as such, has played an enduring, if unrecognized, role in English letters'. That Sidney chose the names of Astrophel and Stella for his alter-ego ('star-lover') and his beloved in the sublime sonnet cycle of that name may likewise be a pointer that Hvězda may have provided him with some of its inspiration.

93 Discussed in greater detail below, in particular Ch. 12.

94 One should be wary also because we do not know in how far the existence of Tanner's treatise and the Hvězda drawings is representative: their survival is probably due to the fact that they were explicitly intended to document the Prater and Hvězda after their 
more ambitious garden complex, the Neugebäude, its layout was determined by it architectural elements to a much greater extent than that of the Prater. Though building may not have been his predominant passion, it is probably safe to conclude that, like his brother, Maximilian was sufficiently interested in it to participate personally in the planning of his commissions. His taste would have been formed by what he had seen in Northern Italy, in the Netherlands and in the Empire, and influenced by at least some of the architectural treatises of his time and their illustrations. In view of the importance of ancient precept and example in the concept and planning of the Prater gardens, one may assume that in planning his architectural commissions he likewise used classical sources - chiefly Vitruvius - and their modern interpretations and adaptations, such as Serlio's treatises. Whether he really studied them himself or whether he had them explained to him by his humanist advisors, must remain an open question.

\subsection{The Imperial Residence: Status quo at Strada's Arrival}

\subsubsection{Residential Requirements}

Though Ferdinand I's representational needs were great, they were easily transcended by purely practical necessities. Some time after its heroic resistance to the Turkish siege, Ferdinand decided to move his court to Vienna. ${ }^{95}$ In the 1540s, after some initial repairs, he began adapting the local residence, the Hofburg, to house his increasing family. Funds were scarce, and what was done initially can be described as the minimum necessary and the maximum possible. The Hofburg proper, later also known as 'Alte Burg', 'the old castle' or 'Schweizertrakt', was a late medieval castle consisting of four wings around a central courtyard, fortified by irregularly placed square corner towers and provided with an elegant Gothic chapel. It was built almost on top of the city's

completion. Few, if any, architectural designs for Imperial commissions from the period have survived.

95 Holzschuh-Hofer 2007 interprets Ferdinand's choice for Vienna as capital as part of his defence strategy against the Turks, as 'the ideological part of a whole military defence strategy of placing the King, subsequently Emperor, as symbol of his permanent presence on the front line.' Christiane Thomas has shown that Ferdinand's adoption of Vienna as his chief residence was not an official act, but merely the result of a process of easy stages (Thomas 1993, pp. 101-103); Altfahrt 2003 provides a graph comparing the length of Ferdinand's sojourns in his various capitals and in other cities of the Empire, based on his itinerary ${ }^{1521-1564}$ (p. 33). But Prague remained important as residence of equal importance until ca. 1547 (Hausenblasová/ Jeitler 2014, p. 26). 

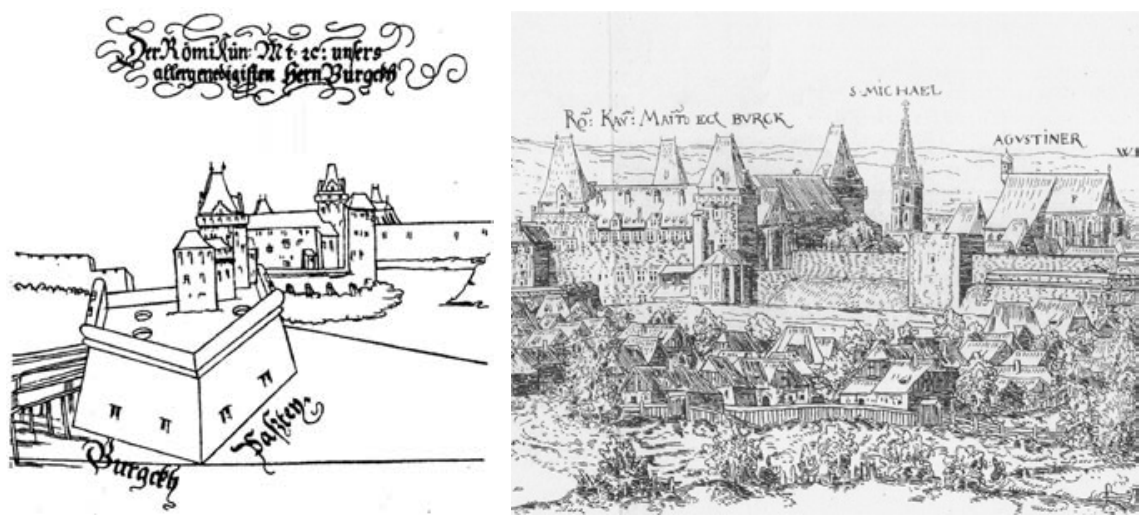

FIGURE 5.70 The Hofburg on the town plan of Vienna by Augustin Hirschvogel, 1547 .

FIGURE 5.71 The Vienna Hofburg in 1558, detail from an engraving by Hans Sebald Lautensack.

fortifications, and there was little space for extension of the building itself [Figs. 5.70 and 5.71; plan, Fig. 5.72].

Abandoning its fortified character would be imprudent in view of the relative proximity of the enemy forces, as had been made abundantly clear by the heavy damage done to the building during the 1529 siege. ${ }^{96}$ As of 1533 most of the damage had been repaired, the available space made habitable and a new set of rooms for Ferdinand himself was realized in the south-west wing overlooking the Hofbastei, the important bastion just in front of the Hofburg. In the following years the mediaeval castle was regularized and restructured to house only the Emperor, his family and their most immediate entourage and to provide space for the most important offices, such as the Hofkanzley. Workspace for other functions was found in other premises acquired for the purpose, other members of the household and for visitors to the court were lodged in private houses all over Vienna. ${ }^{97}$

96 Still in 1538 repairs were necessary of the damage caused by an earlier undiscovered Turkish tunnel of over twenty meters length, which undermined the foundations of the southwest wing and had caused this to subside: Kühnel 1956, p. 256; Holzschuh-Hofer 2014(a), p. 88 , notes $72-74$.

97 Dreger 1914, long fundamental for a history of the development of the Vienna Hofburg, and the researches by Harry Kühnel Kühnel 1956, 1958, 1959, 1961, 1964 and 1971, have now been superseded by the magnificent history of the Hofburg complex undertaken by the Austrian Academy of Sciences and the Bundesdenkmalamt Wien, of which three volumes have been published to date (see Buchinger/Grün/ Jeitler 2011; www.oeaw.ac.at/ikm/ forschung /habsburgische-repraesentation/die-wiener-hofburg (cons. 12-11-2017). For the first version of this Chapter I have been able to use some of its preliminary publications: Holzschuh-Hofer 2007; Karner 2008; Jeitler 2008; the present version incorporates the 


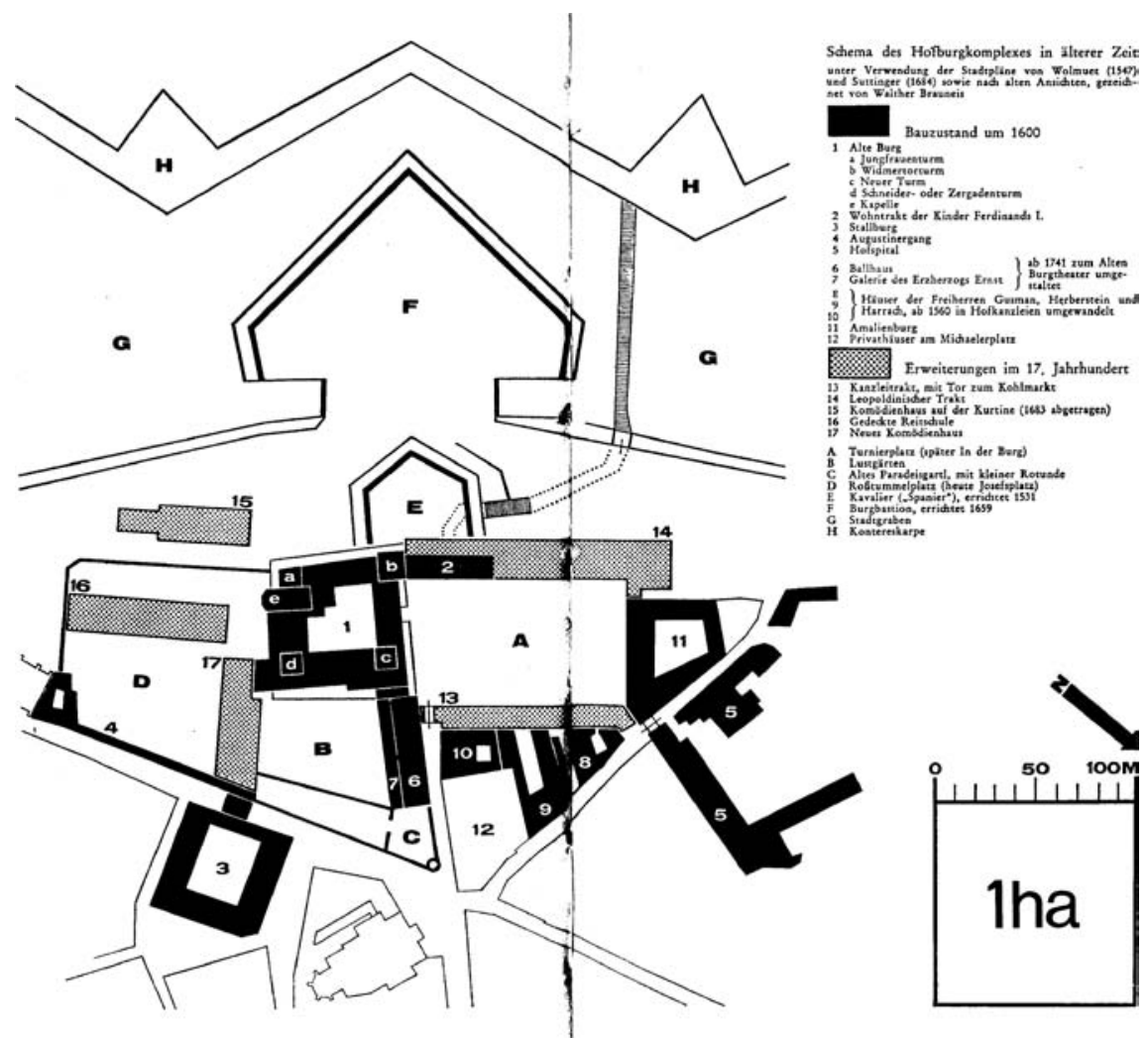

FIGURE 5.72 Plan of the Hofburg: the black parts were existent by 1600 ; from Kühnel, Die Hofburg, Vienna 1971.

The space available being so limited, when Ferdinand came to reside more and more in Vienna and his children grew up and joined him, further additions and adaptations of the Hofburg were necessary. In the 1540 s and early 1550 a number of projects were taken in hand: between 1544 and 1548 Ferdinand's own apartment was transferred from the second to the first or principal floor of the south-west wing; between 1549 and $155^{1}$ a new reception hall, later known as 'Ritterstube' or 'Knight's Chamber', and an antechamber were added to this, which were decorated by Pietro Ferrabosco. ${ }^{98}$ To realize a more convenient and ceremonial access to these spaces and the chapel a new structure was built

relevant results and insights published in the second volume, edited by Herbert Karner: Die Wiener Hofburg 1521-1705: Baugeschichte, Funktion und Etablierung als Kaiserresidenz (Karner 2014).

98 A 'Newen Saal und wartstuben vor der Newen Stuben'; cited in Kühnel 1956, p. 258; cf. Dreger 1914, p. 104; Holzschuh-Hofer 2014(a), pp. 94-95, 101-103. 
in front of the entrance to the chapel, in the corner between south-west and south-east wings; this housed a monumental staircase of three flights, preceded by a huge square hall or landing giving access both to the chapel and to the royal apartment. The plans for this addition were made by Francesco de Pozzo and included an arcade on the ground floor carried on heavily bossed pillars or buttresses, which were not to the taste of some of his colleagues. This gave rise to an extensive debate, in which Ferdinand, at the time absent in Prague, actively participated; it will be briefly discussed later in this chapter. ${ }^{99}$ In the end Ferdinand decided to uphold Pozzo's plans, the remains of which are still visible in the southwest corner of the Schweizerhof.

The north-east wing functioned as 'Frauenzimmer', lodging Queen Anna and her household on the second floor, and the 'Niederösterreichische Kammer', the treasury of Lower Austria. Some of the damages it had suffered in the 1529 siege had been set in order already in the 1530 s, but it was largely reconstructed in the mid-1540s. The Frauenzimmer provided a Chamber, a dining room and a reception hall for the Queen herself, and was preceded by a new, monumental staircase. ${ }^{100}$ It is not clear whether her later successor, Maximilian's consort Maria of Spain, arrived in Vienna in 1551, used the rooms of her late mother-in-law; it was either extended with, or exchanged for an apartment installed for her on the second floor in the completely new-built north-west wing. This apartment, nearer to those both of her husband and her father-in-law, consisted of a larger space ('lange Saal'), an (ante-) chamber, a dining room and a bedchamber. The other floors of this building housed several administrative offices, including a 'Gwelbl', a vaulted (strong-) room for the use of Leopold Heyperger, as 'Burggraf' the chamberlain responsible not only for the day-to day maintenance of the Hofburg, but also for the care of treasures and other valuables. ${ }^{101}$

The north-west wing provided the Hofburg with a new, monumental façade, provided with well-designed window-surrounds in the classical manner, decorated with the symbols of the order of the Golden Fleece [Fig. 5.80]. It also incorporated the only entrance gate to the courtyard, now known as 'Schweizertor', which carries the date $155^{2}$ [Figs. 5.81-5.82]. Gate and window-surrounds are almost the only architectural elements of the sixteenth century in the Hofburg that have been preserved intact. ${ }^{102}$ The northwest wing also incorporated part of the remnants of the north tower, which had become unstable and had been partly demolished. During the reconstruction of thissection a narrow gallery was

\footnotetext{
99 Holzschuh-Hofer 2014(a), pp. 104-108; discussed below, Ch. 5.5.2.

100 Holzschuh-Hofer 2014(a), pp. 104-108.

101 Ibid., pp. 108-111; Kühnel 1956, p. 258.

102 Holzschuh-Hofer 2014(a), pp. 111-122; cf. below, Ch. 5.4; on the window surronds, see below, 5.6.2.
} 
attached to the north-east wing, which was accessible both from the late Queen Anna's Frauenzimmer and from Queen Maria's new apartment: it was topped by a covered terrace or 'Altan' allowing views both on the private, enclosed gardens and onto the square in front of the Hofburg, which came into use for courtly festivities, such as the festival organized by Maximilian on the occasion of a Habsburg family gathering in 1560 , documented in a series of detailed engravings [Fig. 5.73-5.75 and below, Fig. 6.16].103

Of great interest is the first external addition to the Alte Burg proper, which was constructed on top of the gate giving access to the bastion in front of the Hofburg [Fig. 5.74, to the left]. Essentially it is a continuation of the newly constructed northwest wing, consisting of six bays of three stories. On the side of the bastion it was preceded by two superimposed loggias each consisting of four widely spaced arches, the whole topped by an 'Altan', in this case a roof terrace

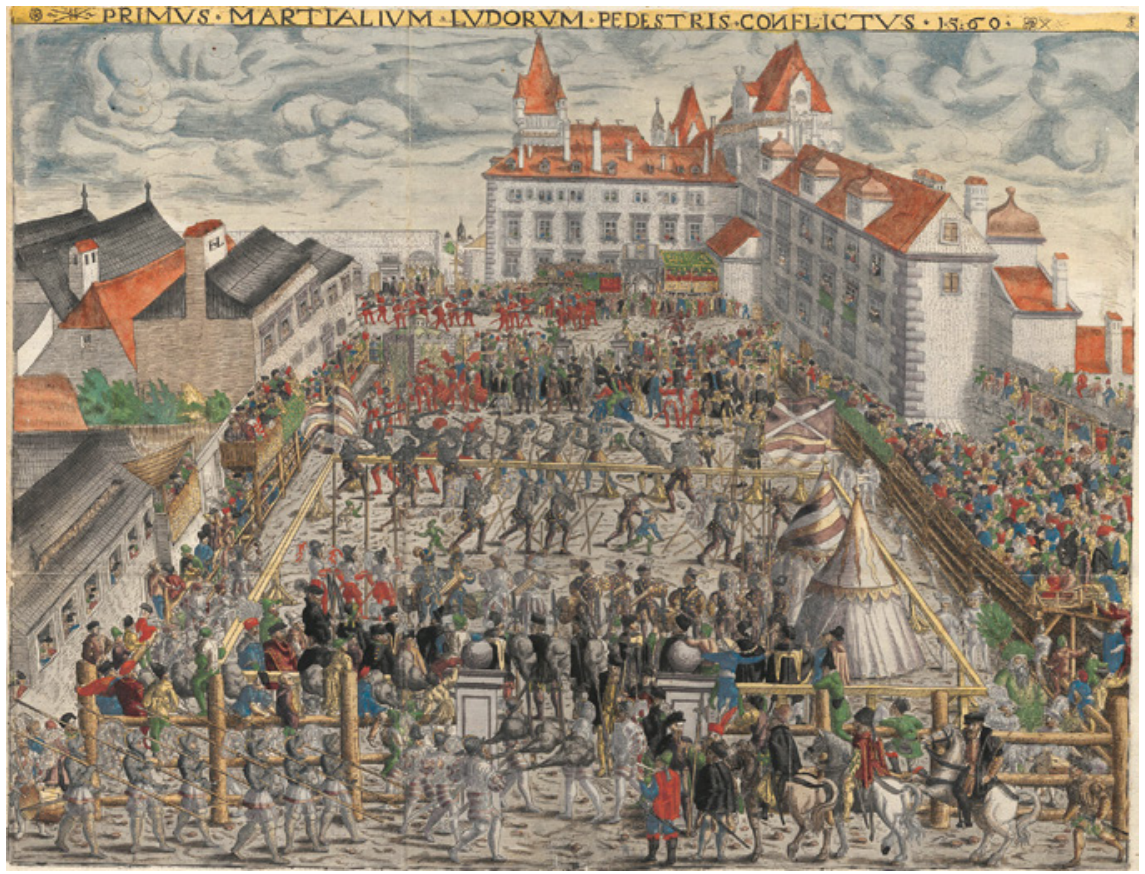

FIGURE 5.73 A joust on foot on the Burgplatz in Vienna, 156o; engraving by Hans Sebald Lautensack from Hans von Francolin, Thurnierbuch (1561).

103 Holzschuh-Hofer 2014(a), pp. 124. The northwest wing was constructed partially in front of the tower, which arose above its roof; the Altan is shown at the left corner of the entrance front of Lautensack's engraving and on a slightly later woodcut from Wirrich's description of a joust of 1571 , where it has been provided with a lean-to roof carried on classical columns and a balustrade (Wirrich 1571; cf. Dreger 1914, Abb. 9; Holzschuh-Hofer 2014(a), Abb. IV.37. Wirrich 1571; cf. Dreger 1914, Abb. 93). 


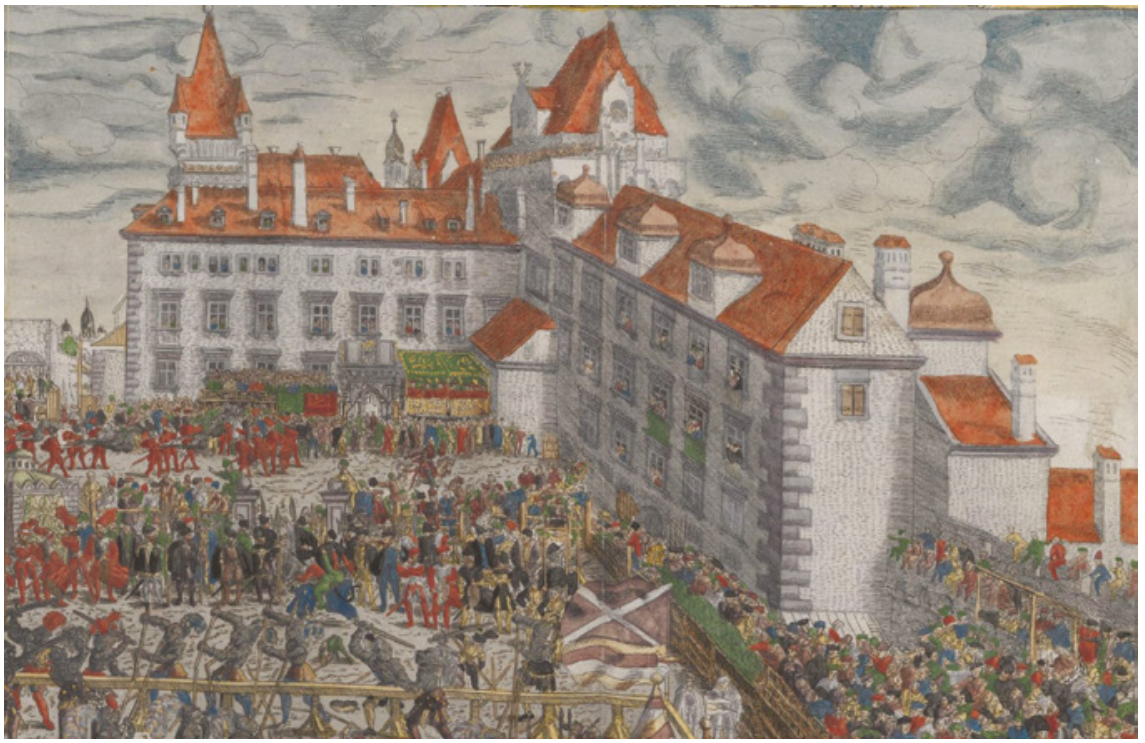

FIGURE 5.74 The Hofburg and the new wing constructed ca. 1553-1556; detail from ill. 5.73.

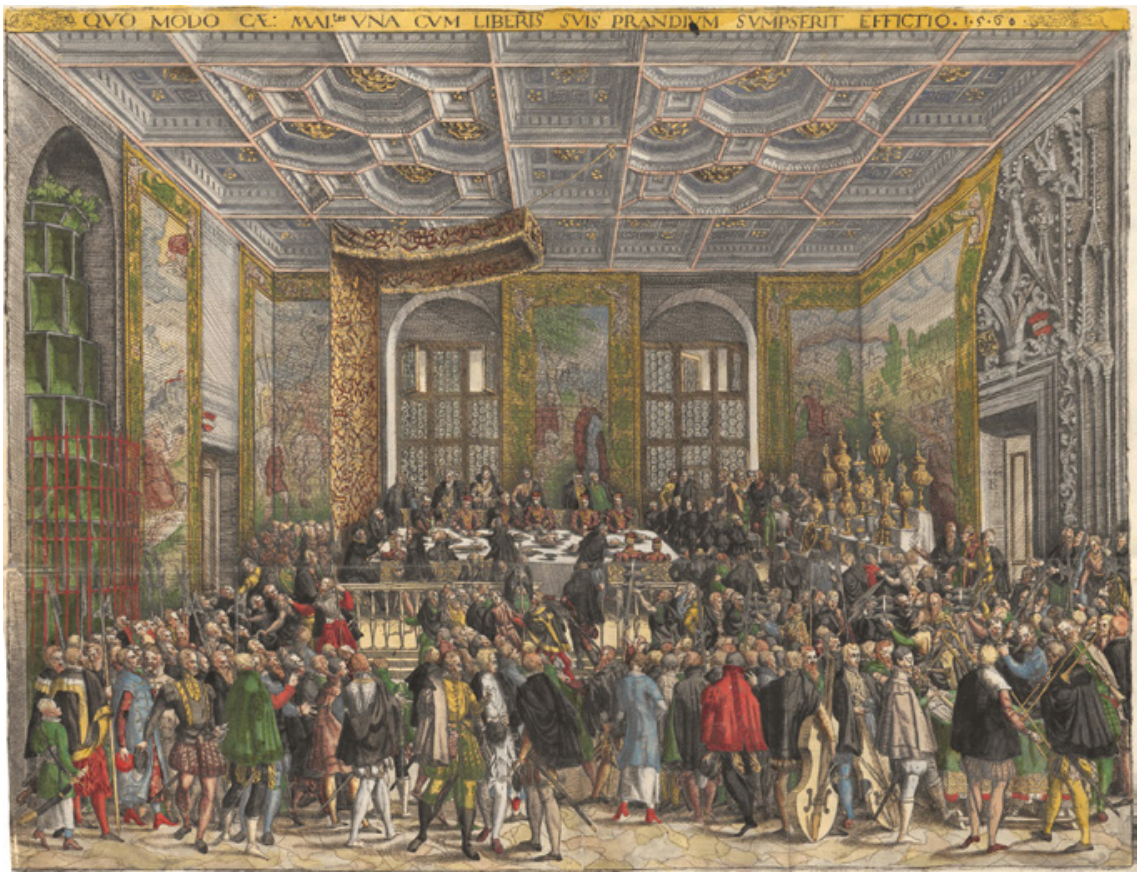

FIGURE 5.75 Ceremonial dinner of Emperor Ferdinand I and his family in the 'grosse tafl stuben' of the Vienna Hofburg, 156o; engraving by Francesco Terzio from Hans von Francolin, Thurnierbuch (1561). 
overlooking the Vienna suburbs and the countryside to the west. This so-called 'Kindertrakt' contained the 'Zimer unnd wonungen <...> für den Khu. Mt. Khinder', the lodgings of 'the children of the Royal Majesty'. It is not clear whether this refers to the youngest daughters of Ferdinand I or to the children of Maximilian and Maria, which seems more likely. ${ }^{104}$ It can hardly refer to Maximilian himself, though he did in fact inhabit the principal apartment on the first floor, which communicated directly with his father's in the adjoining section of the Alte Burg. Begun in 1553, the Kindertrakt was almost completed when Strada arrived in Vienna early in 1558; the architect is not mentioned, but we know that Pietro Ferrabosco was again responsible for the decorative painting of its six principal rooms, a sumptuous decoration suitable to the apartment of the heir to the throne.

In the 1530 s the damage to the gardens of the Hofburg had been restored. Two modest, enclosed 'Lustgärten', communicating by means of a stairway, were complemented by a larger 'Irrgarten' or labyrinth. These were located between the Hofburg and the church of St. Michael towards the east and the Augustinian monastery towards the south. They contained a 'Ballhaus' (a covered tennis-court), a bath and a pond or reservoir to keep fresh fish. The garden was separated from the town partly by a high wall and partly by the Augustinergang, a gallery carrying a covered passage connecting the Hofburg with the Augustinian monastery, the church of which served as court church (the Burgkapelle being too small to hold a significant congregation). In the 1540 s a new Ballhaus was constructed in the north-east corner of the garden, along the Burggasse; after Ferdinand's accession to the Empire this was connected to the north-east corner of the Alte Burg by a building housing his Kunstkammer, his collections objects of particular scientific or artistic value. ${ }^{105}$

Almost nothing of these additions and adaptations has been preserved unaltered, if at all, but some idea is given by the illustrations in Hans von Francolin's Thurnier Buech Warhafftiger Ritterlicher Thate [n], so in dem Monat Junii des vergangenen $L X$ Jars in und ausserhalb der Statt Wienn $<\ldots>$ gehalten. ${ }^{106}$

104 Holzschuh-Hofer 2014(a), pp. 122-124; Ferdinand's youngest son, Archduke Charles, was old enough for his own household, and by 1560 had been provided with separate lodgings in the house of Count Salm, in the direct vicinity of the Hofburg, whereas the Archduchesses were lodged in a house in the Burggasse. It seems likely that they had inhabited the Frauenzimmer before that, as a reference in 1548 to 'der jungen Kunigin Zimer' (ibid., p. 96 and note 135) can hardly refer to Maria of Spain, who would arrive in Vienna only three years later. It was not unusual to refer to Ferdinand's children with a royal title (f.i. Seisenegger's portrait of Archduchess Eleonora, afterwards Duchess of Mantua, as a child, $\mathrm{KMH}$, Gemäldegalerie 872; cf. Heinz/ Schütz 1982, cat nr. 65, pp. 98-99 and ill. 56.).

105 Jeitler/ Martz 2014 188-192; Kühnel 1956, pp. 258-259; Holzschuh-Hofer 2014(c).

106 Francolin 1561. 
It describes the festivities organized in honour of a visit of Duke Albrecht $\mathrm{v}$ of Bavaria and his consort, Archduchess Anna, a rare occasion on which Ferdinand I's family were all together. One print, by Hans Sebald Lautensack [Figs. 5.73-5.74], documents a joust taking place on the Turnierplatz (now In der Burg), looking towards the Hofburg from the north-west: the north-west wing with the Schweizertor can be seen in the centre, the extension for Ferdinand's children that had just been completed on the right. The image shows a very sober architecture in the classical style: the plain plastered walls were held together by rusticated quoins at the corners and pierced by rectangular windows set in simple stone frames carried on brackets and topped by flat entablatures. The steep roofs were carried on narrow cornices, that of the Hofburg proper was dotted by dormer windows and tall chimneys, while that of the extension was interrupted by three larger, turret-like dormers topped by small square cupolas covered with sheets in copper or lead. The extension appears to have had the same dimension and rhythmic articulation as the main facade, except for the upper (third) floor, which was higher and had taller windows. Presumably it was intended at some future time to modify the facade of the main building in a similar way, thus creating another floor of more commodious lodgings.

Of the interior decoration of the Hofburg in this period hardly more is known than that several rooms and the Augustinergang had painted decoration executed by Pietro Ferrabosco and that the furniture included a great many tapestries. The only image we have is another, impressive print from Francolin's Thurnierbuch, showing the festive and ceremonial lunch ('Mitttagmal' or 'Fruemal') of the Imperial family, which took place on Corpus Christi, the third day of the festivities, i.e. 14June 156o. According to Francolin, who described the placing in detail, the banquet took place in the 'grosse tafl stuben', that is the large dining chamber that appears to have been identical with one of the principal chambers of Ferdinand's apartment, also known as 'Grüne Stube' (Green Chamber) or 'Wartstube' (antechamber). ${ }^{107}$ The print [Fig. 5.75] is signed by the court-painter Francesco Terzio. It provides a fascinating image of court-ceremonial on festive occasions, showing the Imperial family dining in public, served by their highest-ranking courtiers. These hand them the food provided in the several courses ('portate') brought to their table in a ceremonial procession preceded by an official carrying a rod of office, wending its way

107 Francolin 1561, § xv: 'Von Procession': 'Nach disen allem / ist hochgedachte Rö: Kay: May: wider haimb geritten/ und das mittagmal in der grossen tafl stuben eingenommen / und zu thisch gesessen wie du hernach in diser nachvolgender figur sehen wirdest'. § xxvI, 'Vom Fruemal', gives the disposition at table (unnumbered pages). The print describes itself as: 'QUO MODO CAE: MAI: ${ }^{\text {tas }}$ VNA CVM LIBERIS EIVS PRANDIVM SVMPSERIT EFFICTIO 1560'. The location of this space is now clarified by Holzschuh-Hofer 2014 (a), pp. 127-129. 
through the crowd of lower-ranking courtiers held back by members of the Imperial guard ('Hartschiere' and 'Trabanten') carrying halberds. In the front on the right musicians of the Emperor's chamber-a cornett, three shawms and two sackbuts, grouped around a table with their open scores-add lustre to the occasion, while two viola players are waiting their turn. ${ }^{108}$

The print also gives a detailed and faithful image of the disposition and the decoration of the dining chamber. It is clear that the room had been explicitly adapted for its particular function: next to the tall windows a huge dais raised the dining table three steps above the rest of the chamber, from which it was separated by a balustrade. Above the head of the table, the Emperor's seat, a huge canopy of figured damask underlined his status, while a huge 'Kredenz' or sideboard of four steps against the wall on the right displayed a profusion of huge and splendid silver and silver-gilt vessels and plates, part of the Emperor's treasure. The diners were sitting at three sides of the table on benches with backs to them, all covered in rich damask or velvet cloth.

The Gothic portal partly visible on the right shows that the room always had been part of a representative section of the Hofburg: it dated from the late fifteenth century, when the medieval 'Tanzsaal' or ball-room was split up in several smaller spaces. The traditional monumental Kachelofen on the left, a huge stove constructed of green ceramic tiles, assured comfort also in winter. While the dais was probably executed in wood, which again would heighten comfort in winter, the floor of the chamber appears to have been executed in something like crazy-paving. It is difficult to decide whether this was actually the case, which seems unlikely: probably the engraver attempts to indicate a polished marble floor. Though according to the sources most floors in the Hofburg were of wood or were covered by 'Estriche', terracotta tiles, this very representative room may have been an exception. ${ }^{109}$ The walls were covered in a set of huge sixteenthcentury Flemish figural tapestries depicting what appear to be battle-scenes.

The print gives pride of place to the most spectacular element in the decoration, the splendid timber ceiling. This consisted of huge beams dividing the surface in square and octagonal sections filled with what were probably painted, possibly sculptured and gilt architectural motifs, each panel centring on a huge rosette. This ceiling was obviously the one up-to-date Renaissance

108 I am grateful to Jan Bouterse for providing me with the correct names of these instruments. 109 The anonymous artist who made the print illustrating the temporary ball-room created in wood and canvas uses a similar convention to indicate the faux marbre of the huge wooden Corinthian columns carrying the roof (cf. below, Ch. 6.4). The treatment of the floor in the beautifully illuminated copy presented to Ferdinand himself strongly suggests marble (illustrated in Karner 2014, Fig. \#\#\#). 


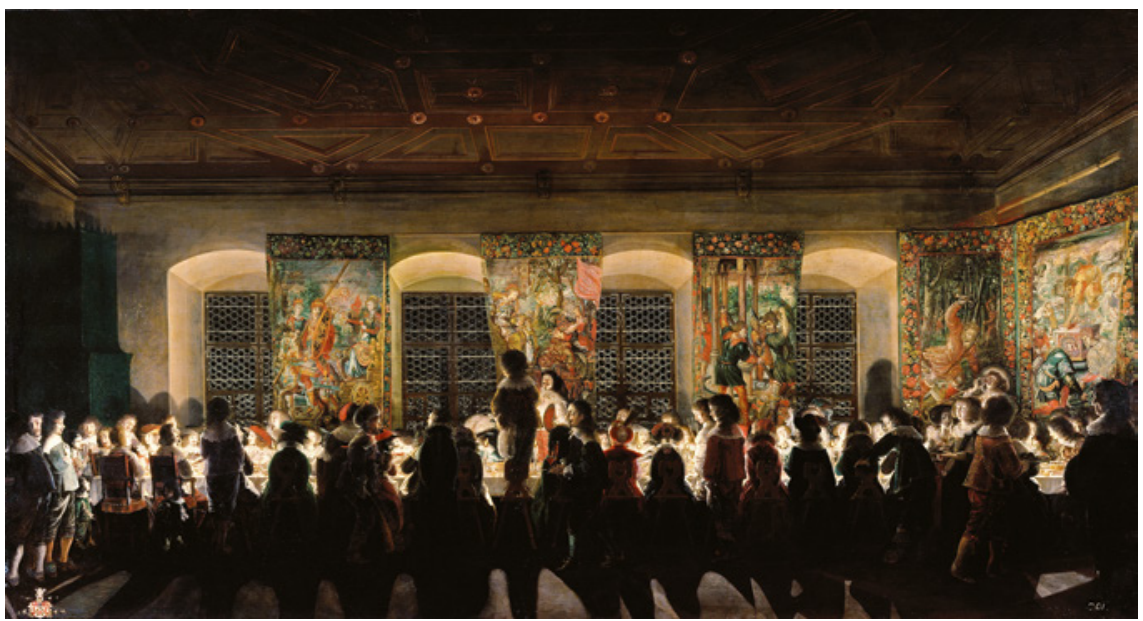

FIGURE 5.76 Wolfgang Heimbach, Nächtliches Banquet, Vienna, Kunsthistorisches Museum.

element in the fixed interior of the Taflstube. The room probably was adapted, or at least its ceiling created, expressly in anticipation of the festivities organised by Maximilian to add lustre to this family gathering. ${ }^{110}$

A good impression of the appearance of another important reception room is given in a painting by Wolfgang Heimbach of a festive banquet at night [Fig. 5.76]. On the basis of a detailed examination linked to structural research of the south-west wing of the Hofburg, Walter Gerhardt has demonstrated that the painting gives a detailed and exact image of the 'Saal' adjoining Ferdinand's chamber, which would later be known as the 'Ritterstube', Knights' Chamber. Though the painting is dated 1640 , the interior appears to have been maintained in its mid-sixteenth century state, which closely resembles that of the Taflstube: windows in deep round-headed niches, a similar monumental green Kachelofen in the corner, even the same type of Flemish tapestries covering the

110 Francolin 1561, §II, 'Vom Gebew', describes some of the preparations for the festival: 'Ehe man die Schrifftliche Verkhündung der Thurnier Publiciert / hat man in der Burckh und auff der Platz vor dem Kayserlichen Pallast / sich gerüstet mit allerlay notdurft zum handel tüchtig und füglich'; he mentions in particular the construction of the temporary Tanzsaal, basically a huge tent or marquee located on the bastion in front of the Alte Burg (cf. below, ch. 6.4), and of the various boats used for the planned naval battle, but does not refer to specific adaptations of the Hofburg itself. In the beautifully illuminated version from the copy presented to the Emperor, illustrated in Holzschuh-Hofer 2014(a), p. 128, Abb. IV.39, the ceiling is coloured light grey, blue and pink, with gilt rosettes filling the compartments. 
walls. ${ }^{111}$ Only the coffered ceiling is of a different type: it seems to be a flat timber ceiling, resting on a cornice carried on stone brackets. Its triangular, rectangular and square compartments appear to be superimposed on this ceiling, and they probably contain panels painted with suitable mythological scenes. In fact, it strongly resembles the description of the ceiling of the Goldene Saal in the Hofburg at Innsbruck, decorated with 'fantasies' painted by Domenico Pozzo, which has already been discussed in detail in the preceding chapter.

\subsubsection{Work in Progress}

At the time Strada arrived in Vienna some of these projects were still under way. Ferdinand's accession to the Imperial throne greatly increased his need for a residence sufficiently representative to reflect his exalted status. Several other projects were being planned, the principal one being the construction of the Stallburg, a separate residential building for the household of King Maximilian, as heir to the throne. For such projects Strada's specific competence must have been particularly welcome: at this time his theoretical knowledge and practical experience of the most up-to-date architectural and decorative design was probably unique at court. Few of the artists in Ferdinand's employ were capable of such avant-garde design: that is of classical architecture in which the Vitruvian precept was correctly applied and decorative elements were designed in the manner of the Italian Renaissance. Initially this manner was fashionable at the princely courts of Europe-Fontainebleau is the most obvious example-and with a small cosmopolitan and intellectual circle consisting mostly of aristocrats closely connected with these courts.

It did allow the inclusion of local, traditional or 'vernacular' forms and elements: again Fontainebleau is an obvious example, but it is perhaps best illustrated by a comparison between Serlio's two designs for the Château of Ancy-le-Franc, an ideal, classical, Italian version [Fig. 5.78] as opposed to an equally classical, but less strict and quite French version, the one which was actually executed [Fig. 5.77]. ${ }^{12}$ Even in such cases, however, the designer was expected to demonstrate a perfect command of the rules governing the application of the Vitruvian orders and the proportional systems that were derived from these by Renaissance theorists and practitioners.

By the 1550's, north of the Alps, such reliance on theory gave this manner a particular appeal to highly educated, intellectual patrons, who had been introduced to it during their travels. Moreover it would be exclusive because its

\footnotetext{
111 Gerhardt 1995; the precision of the painting is shown by the fact that Guy Delmarcel could identify two of the tapestries (ibidem, p. 272, n. 8); Karner 2014, pp. 168-169.

112 BSB-HS, Cod. Icon 189, f. 17r.
} 

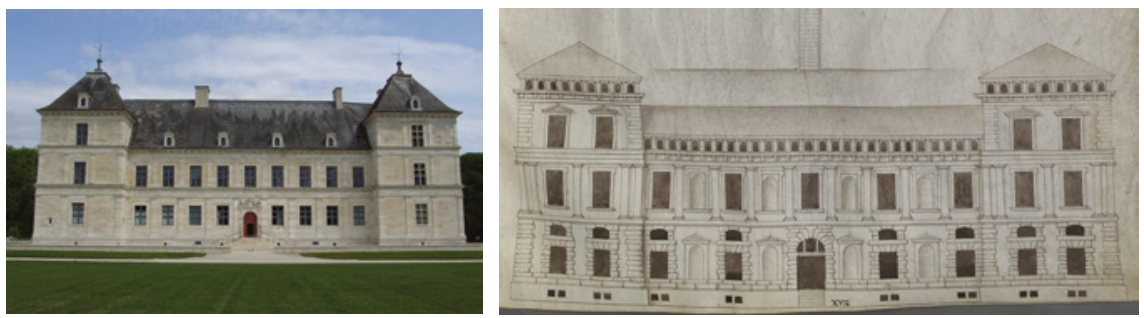

FIGURE 5.77 Sebastiano Serlio, Château de Ancy-le-Franc, ca 1545.

FIGURE 5.78 Sebastiano Serlio, Alternative designs for Ancy-le-Franc, in the Munich ms. of the Sesto Libro.

application was limited to literate and intellectually ambitious artists: it would be out of the range of merely practically trained, illiterate master-masons such as Benedict Kölbl. Certainly it was a manner sufficiently distinct from the vernacular to be explicitly recognized as such: thus in a letter to his Venetian correspondent Niccolò Stopio Hans Jakob Fugger would describe Strada's newly built house in Vienna as having 'una facciata alla Italiana', a facade in the Italian manner. ${ }^{113}$

As we have seen, Ferdinand as well as his two elder sons had already demonstrated their taste for this manner. Being mostly based on ancient Roman architecture, the style was moreover highly suitable for the projects of the Holy Roman Emperor, who was generally considered the direct successor of the rulers of the ancient Roman Empire. This interest is reflected in details of the Hofburg realized before Strada arrived at court, such as the ornamental plaque commemorating his earliest interventions in the Hofburg [Fig. 5.14] and in the exquisite door- and window frames and relief plaques decorating the earlier, lower part of the Prague Summer Palace [Fig. 5.19], based on a model from Serlio's Fourth Book [Fig. 5.20], both examples which have been discussed above. ${ }^{114}$

Some of the masters active in Prague may well have contributed to the projects in hand in Vienna: a particular instance was first noticed by Moriz Dreger, who compared the upper lintels or friezes of the windows in the Prague Summer Palace [Fig. 5.79] with those of the entrance facade of the Vienna Hofburg, dated 1553 [Fig. 5.80]. They both include oddly crenelated cartouches or plaques, flanked by fire steels and flints, emblems of the order of the Golden Fleece that were doubtless suggested or imposed by Ferdinand himself. This close link - the Vienna window frames are reduced and simplified versions of the Prague ones-suggests that one of the architects engaged on the Summer

113 On Strada's house, see below, Ch. 7 .

114 Ch. 5.2.1. 

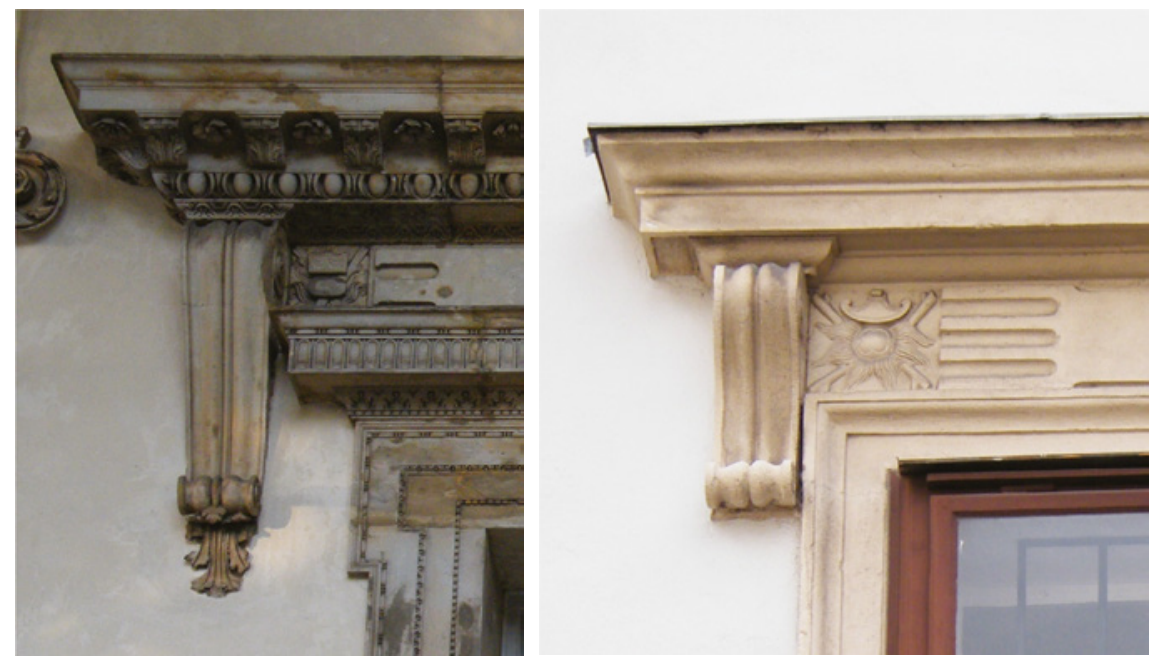

FIGURES 5.79-5.80 Lintel and entablature of a window frame of Queen Anna's Summer Palace, ca 1540-1545, compared to the Lintel and entablature of a window frame of the Schweizerische Trakt of the Hofburg, Vienna, ca 1553.

Palace also was asked to provide designs for the Vienna facade, or at least that the Vienna designer was well informed about what happened in Prague. Whoever he was-Pietro Ferrabosco remains a candidate-he must also have been responsible for the design of the Schweizertor in the same facade [Fig. 5.81 ].115

\subsection{The Architectural Infrastructure at the Imperial Court:}

\subsubsection{Available Talent}

Once Maximilian was in a position to really start building, just like his relatives in Brussels and Jülich he needed at least one or two architects of the new, 'Vitruvian' kind: architects who preferably were born and bred in Italy or who would have visited Italy and were therefore aware of recent developments. Except for Bonifaz Wolmut and possibly Sigismund de Preda, he would not find

115 Dreger 1914, pp. 117, and $A b b .70$; see also Holzschuh-Hofer 2010, who shows that similar surrounds with fire steels-and-flints were also used in the refurbishment of the castle at Pressburg/Bratislava. Perhaps one of the members of the Spazio family, Italian masons and architects active both in Prague and in Vienna, was responsible for the design. At least as far as the design of the window frames is concerned, this need not have implied any direct involvement in the actual building process, a drawing sent form Prague would have sufficed. Besides Ferrabosco, Bonifaz Wolmut, who had already worked in Bohemia, where he would later settle, is a likely candidate. 
these among the architects and master-masons regularly employed at court. Some of these had been working for his father and great-grandfather since decades, such as the learned and versatile Moravian Hans Tscherte/ (Jan Čert; $\dagger$ 1552), the friend of Dürer and father-in-law of the painter Jakob Seisenegger, who had settled in Vienna in 1509, or the master-mason Benedikt Kölbl ( $†$ after 1569). Kölbl must have been a very competent master-builder, if he was allowed to succeed Tscherte as chief architect in Vienna in the face of the criticism that he could neither read nor write. Among the Italian masters we find Sigismund de Preda (from Pisa, died probably ca 1549), who is first documented in Vienna in 1543, and is possibly identical with the 'Maister Sigmund' who had supervised the building of the Stadtresidenz at Landshut for Duke Ludwig X of Bavaria, shortly before; and the Milanese Francesco da Pozzo (ca. 1501/2after ${ }^{1558}$ ) who had entered Ferdinand's service in $1538 .{ }^{116}$ In Prague some other masters were working, such as Paolo della Stella, the architect and possibly the designer of the model for the Belvedere, the summer palace Ferdinand had built for his consort, Queen Anna, in the gardens of the Hradčany. His two assistants Giovanni Battista and Giovanni Maria Aostalli were members of one of the dynasties of masons from Northern Italy that would remain so typical for the history of architecture in Central Europe. They were responsible for the completion of Ferdinand's Belvedere, and - with Giovanni Lucchesi-for the construction of Hvězda, Archduke Ferdinand's star-shaped hunting-lodge mentioned earlier.117

A central position was occupied by Hermes Schallautzer (1503-1561), a member of an old patrician family with a strong political position in Vienna. After the 1529 siege of Vienna he was put in charge of the new fortifications and in 1544-1545 functioned as Proviantmeister, responsible for the provisioning of the troops fighting the Turks in Hungary. Doubtless he demonstrated his talents in logistics, management and organisation, for a year later he became a member of Ferdinand's Council and was subsequently appointed Bausuperintendent, bearing the final executive responsibility for the landesfürstlichen Gebäude' in Vienna, that is both the fortifications and all other construction work undertaken by command of Ferdinand, such as the extensions of the Hofburg. This was a position which had not existed before, and would not be renewed after Schallautzer's death. It was primarily a managing and coordinating task: it included the recruitment of suitable masons and the acquisition of building materials for, as well as the financial administration of the current

116 These architects discussed in Kühnel 1958 and Kühnel 1959. On Landshut, see above, Ch. 2.3; the identification of De Preda with the supervising master at Landshut was first proposed in Sarzi 1988.

117 Renaissance in Böhmen 1985, p. 207. 
projects. ${ }^{118}$ It is not surprising that his name turns up in the documents relating to most of the projects in hand at the time. Schallautzer, moreover, was an intellectual, and he was sufficiently historically interested to collect a number of stones with Roman inscriptions that had come to light during building works on several locations in Vienna. He set them up in his garden, creating a small lapidarium which can count as perhaps the earliest collection of antiques in Austria, and published a note on his finds illustrated by Hans Sebald Lautensack and including comments on them by his nephew, Wolfgang Lazius, both of whom we have met earlier. ${ }^{119}$

Most of the architects employed appear to have been technicians, competent builders or master-masons, rather than artists. Exceptions were the Italians Pietro Ferrabosco and Domenico dell'Allio and the native Viennese Bonifaz Wolmut. Pietro Ferrabosco was born at Laino near Como in 1512 or 1513; he had trained as a painter and had first been employed by Ferdinand in that capacity (1547). After 1551, when he was forced to take over the management of the restructuring of the castle at Kaiserebersdorf from his brother Lorenzo, who had suddenly died, he was soon also charged with often quite important architectural commissions. ${ }^{120}$ Unlike Wolmut he had never trained as a master-builder, but appears either to have learned the job on site, for instance when executing commissions of painted decoration, such as the ceiling of the new 'Saal' and 'Zimmer', a reception hall and -chamber of the Vienna Hofburg for which he was paid in 1549, or - more likely — during the five years that he accompanied the Imperial commander, Eck von Salm, to the Turkish border, doubtless initially acting as surveyor and draughtsman, but soon making designs and models of projected fortifications.

Ferrabosco certainly was an architect in the fullest sense, not only providing designs, but also organizing and supervising their execution: he is first mentioned in an architectural capacity as 'Meister Peter Fero Boschko Maller, so über die Gesellen Baumeister'. It is clear that he was really supervising these masons, at work at the Imperial castle at Pressburg in 1563, because it was stipulated that he should not absent himself from the site for longer than two weeks. ${ }^{121}$ In a request for increase of his salary from 1559, Ferrabosco claimed

\footnotetext{
118 Kühnel 1959, pp. 311-316.

119 Exempla aliquot s. vetustatis Rom. in saxis quibusdam, opera nobilis viri D. Hermetis Schallauczeri <...> his Viennae erutis una cum interpretatione Wolfgangi Lazii medici et historici, Viennae Austriae 156o; Kühnel 1959, p. 315; Von Busch 1973, pp. $19-21$.

120 On Ferrabosco, see Kühnel 1958, pp. 272-276; Kühnel 1964, p. 41; Krčalová 1969; Lietzmann 1987, pp. 107-110. Podewils 1992, pp. 165-168; his role at Kaiserebersdorf documented in Müller / Krause 2008, pp. 44-46.

121 Krčalová 1969, p. 184.
} 
that after his travels with Count Salm, Ferdinand 'mi diede il carico della fabrica di Posonia, di Ebersdorff et finalmente del castello qui in Vienna': though this does not necessarily mean that he was the only architect employed on these projects, it does suggest that he was the most important one, and that in the preceding decade he had been acting supervisor of the building activities at the Vienna Hofburg, the Imperial residence at Pressburg and the castle of Kaiserebersdorf just outside Vienna.

The best preserved example of his work is probably the Schweizertor of the Vienna Hofburg of $155^{2}$ [Figs. 5.81-5.82].122 In the 1560 s he would moreover be employed in inspecting and designing fortifications both in Vienna itself and in Hungary, and supervising their construction. His contribution to the Imperial projects was quite considerable, and he was probably the leading architect at the Imperial court and one of the few to be employed both in Vienna and in Prague. Already in 1556 he was ennobled by Ferdinand I and his services continued to be highly regarded, if Rudolf II granted him, two months after Maximilian II's death, no less than two thousand Thaler in order to buy himself a house. ${ }^{123}$
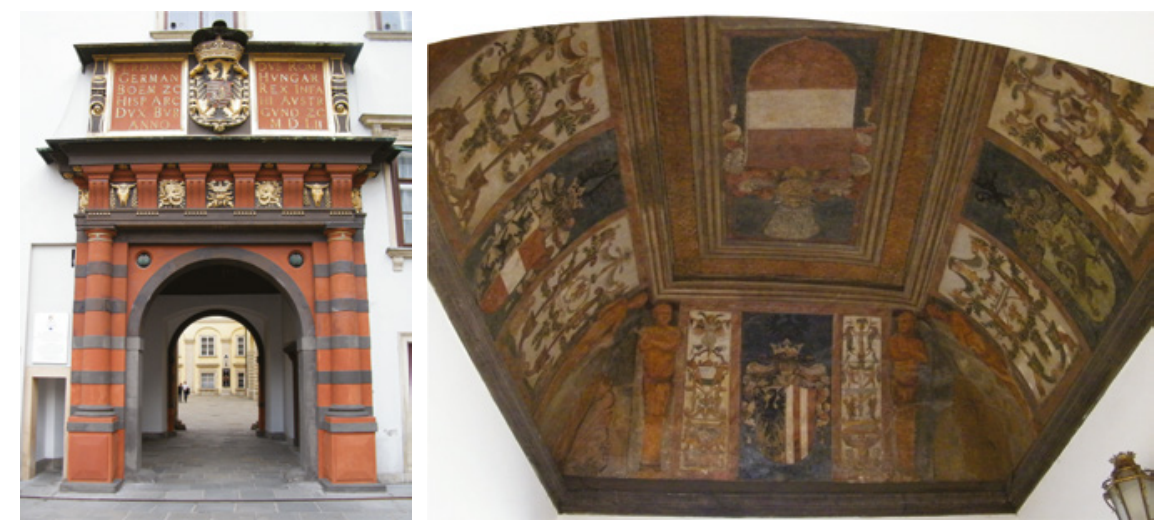

FIGURE 5.81 Vienna, Hofburg: the Schweizertor, $155^{2}$.

FIGURE 5.82 Pietro Ferrabosco, ceiling decorations of the Schweizertor.

122 Or isn't it? The actual records refer to payments for painting the coat of arms and the ceiling of the passage of the Schweizertor. In view of the strictly correct classical order of the portal itself, I am tempted to attribute its design to Bonifaz Wolmut. Results of recent structural investigations have been published in Holzschuh-Hofer/ Beseler, 2008; Holzschuh-Hofer 2014, pp. 111-122.

123 Kühnel 1958, pp. 272-276; Krčalová 1969; Lietzmann 1987, pp. 107-110. On Wolmut, see Erich Hubala, 'Palast- und Schlossbau, Villa- und Gartenarchitektur in Prag und Böhmen', in: Renaissance in Böhmen 1985, pp., 27-114, in particular pp. 105-110. 
Domenico d'Allio or dell'Allio was born in 1515 into a family of master masons and architects from the Valle d'Intelvi near Como. ${ }^{124} \mathrm{He}$ can be considered as one of the foremost military engineers working for the Habsburgs in the sixteenth century. Following in the footsteps of his father Martino, he was mostly active along the south-eastern borders of Austria, but was also employed elsewhere, occasionally also for non-military architecture. His talent is best visible in the beautiful, well proportioned Landhaus of Styria in Graz, the principal section of which was built from his designs between 1557 and 1564 [Fig. 5.83 and below, Fig. 10.1-10.2]. This shows him to have been schooled in the Lombard tradition of the late Quattrocento, as is particularly evident from the spacing of the windows - note the central bay-and the window frames themselves. In contrast the beautiful arcades of the inner courtyard demonstrate an awareness of more recent developments in Italian classical architecture, the origin of which will be subject of discussion below. Notwithstanding the high quality of his work, there are no indications that Dell'Allio was employed in the residential building of the Habsburgs in Vienna or Prague.

Most of the architects and master-masons involved in military architecture must have been conversant with mathematical and technical literature, such the Underweysung der Messung written by Tscherte's old friend Albrecht Dürer. But few of them would have had a more theoretical - that is, Vitruvianbackground, let alone have been abreast of recent developments in design as practised in civic and ecclesiastical architecture in Italy. The Schweizertor makes clear that Ferrabosco, as a painter and an Italian, was better informed than most of his colleagues, though he had never visited Rome. But oddly enough the one real exception was no Italian at all: Bonifaz Wolmut (active in 1522; died Prague 1579). This is perhaps not quite a coincidence, since Wolmut, apart from being a competent master-mason, was an intellectual, owning a library of which the catalogue has been preserved. He was the one architect of genius employed by Ferdinand I, and the one designer that really and thoroughly understood the spirit of the proportional system of the classical orders. He developed a personal language which Hubala appropriately described as the 'maniera grande des Bonifaz Wolmuet'. It is perhaps best exemplified in the monumental Ballhaus of Prague Castle (1567-1569) [Fig. 5.84] and in the late, extraordinary, proto-baroque Lutheran parish church of SS. Peter and Paul at

124 On Dell'Allio, see Cavarocchi/Trier/Böning 1992. 


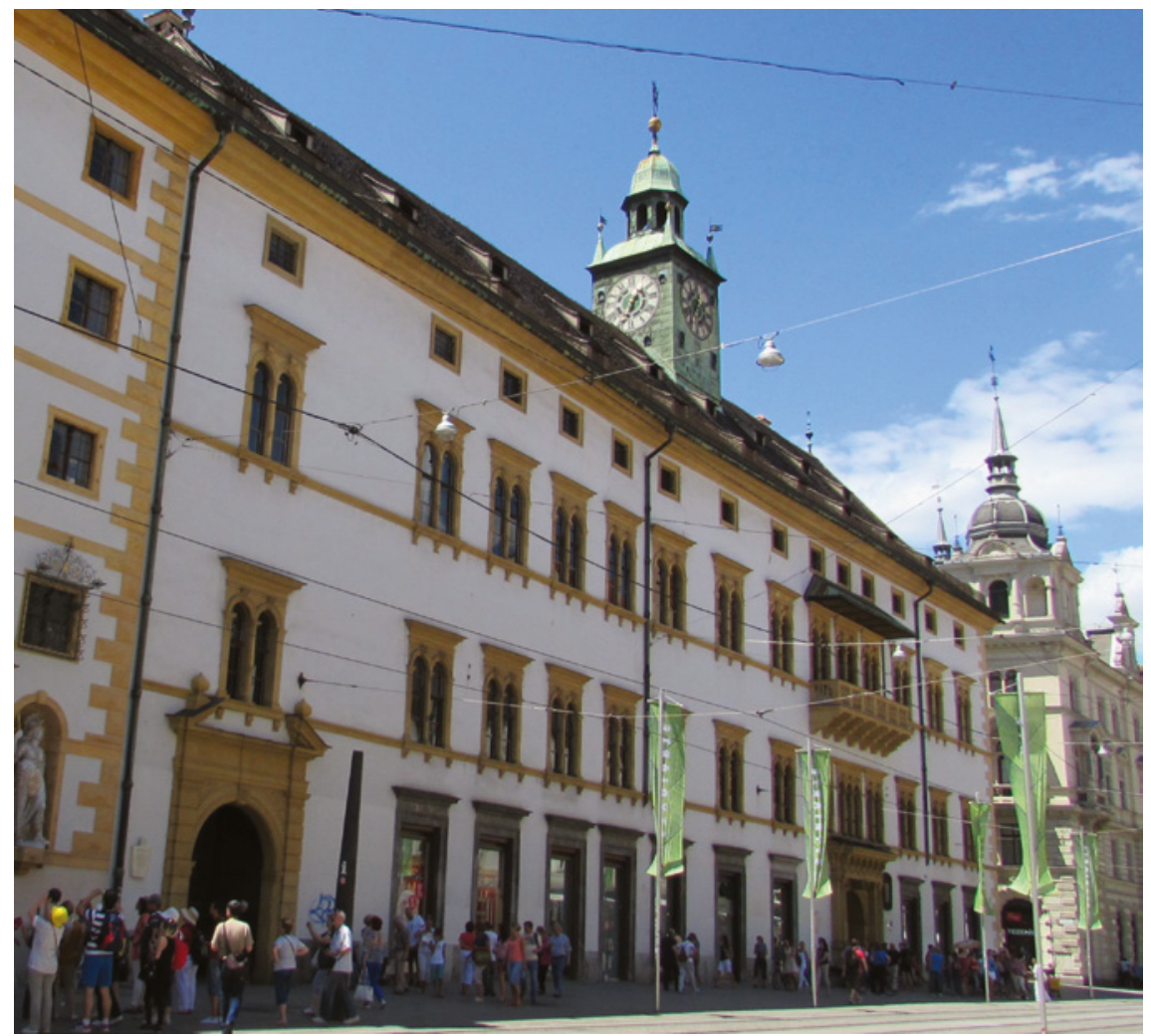

FIGURE 5.83 Domenico dell'Allio, the Landhaus in Graz: Facade, ca. 1556-156o.

Kralovice (1575-1581) [Fig. 5.85] that has convincingly been attributed to him by Jarmila Krčálová. But Wolmut was called to Prague by Archduke Ferdinandhe was first mentioned as a 'königlicher majestet paumeister' in 1554-and would remain working in Bohemia for the rest of his career. ${ }^{125}$

Both Ferdinand I and his two sons must have been aware of the limits of these masters, too few of whom were, however competent in the practice of their craft, sufficiently educated to be able to assimilate, understand, and cre-

125 The Ballhaus is perhaps the most outstanding Renaissance building in the whole of the Habsburg territories. On Wolmut, see Erich Hubala, 'Palast- und Schlossbau, Villa und Gartenarchitektur in Prag und Böhmen', in: Renaissance in Böhmen 1985, pp. 27-114, especially pp. 105--108; Krčalová 1972. As the character and quality of his works indicate, Wolmut was a learned architect: the inventory of his library, acquired at his death by the Czech poet Pontanus (Jiři Barthold Pontanus z Breitenberka), has been published in Kořán 196o. Little is known of Wolmut's early career, but his style presupposes a visit to Italy. The forthcoming book on Wolmut by Sarah Lynch, based on her Princeton dissertation, 'Ein liebhaber aller freyen khünst': Bonifaz Wolmut and the Architecture of the European Renaissance (January 2017), will throw fresh light on this outstanding artist. 

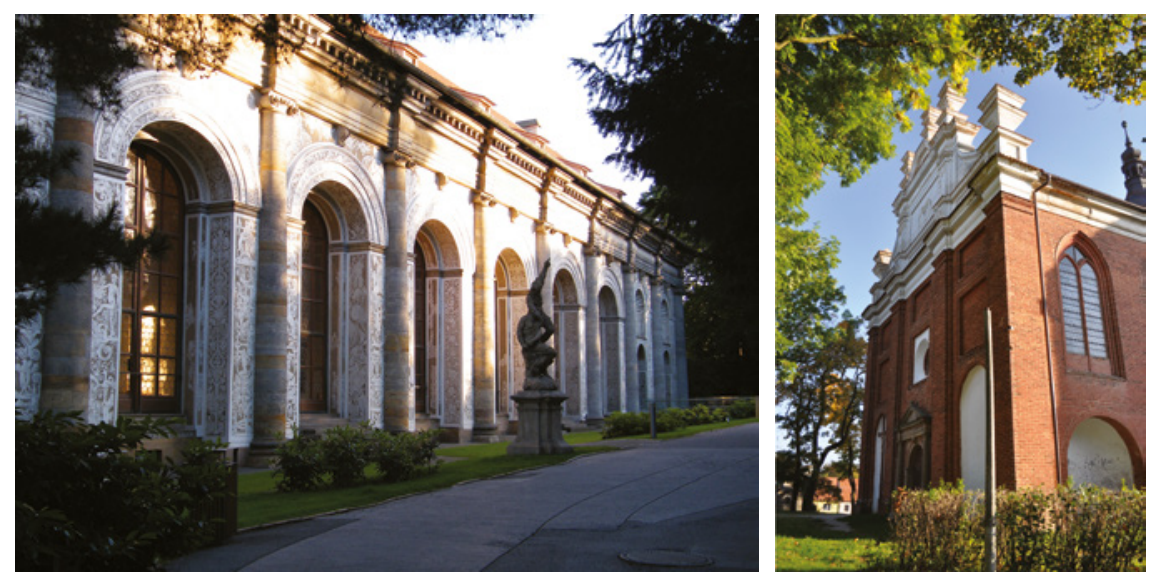

FIGURE 5.84 Bonifaz Wolmut, Prague Castle, Ballhaus (1567-1569).

FIGURE 5.85 Bonifaz Wolmut, Church of St Peter and Paul at Kralovice (CZ), (1575-1581).

atively apply the theory underlining the new, Vitruvian manner of architectural design and the latest developments in fortification. That they looked around for masters who would meet these criteria is not surprising.

One example is the Augsburg Town Architect Hans Tirol ('Ioannes Tirollus Republicae Augustanae aedificiorum publicorum Prefectus'), who combined this charge with his father's function as herald, and as a print publisher and engraver closely cooperating with his father-in-law Jörg Breu the Elder. Two splendidly illuminated sets of codices, preserved in Eton College and in the Escurial, illustrating scenes from history and countless coats of arms, bear witness to his expertise as a herald and an antiquary. The character of the latter does not indicate that his expertise as an architect was much influenced by up to date developments in Italy, or even by Serlio's recent publications. Ferdinand asked him to come to Prague in 1551, where he was involved in the design and /or the construction of the upper level of the Summer Palace. ${ }^{126}$

A second example is the intellectual Jacopo Aconcio (1492-1566) [Fig. 5.86]. The contact between Maximilian and the Italian may well have been motivated at least in part by this consideration. Aconcio was a lawyer from Ossana near Trent, who appears to have been first called to court by Ferdinand I. He soon became acquainted with Maximilian, to whom he later sent a copy of the 1558 edition of the Dialogo nel qual si scuoprono le astutie che usano lutherani per ingannar i semplici which he had written in Vienna. ${ }^{127}$ Doubtless

126 Bažant 2006, pp. 20-21; on Hans Tirol, see Lange 2011, pp. 49.

127 Aconcio to Maximilian II, 27 November 1558, publ. in Aconcio/ Köhler/ Hassinger 1932, p. 97 . 


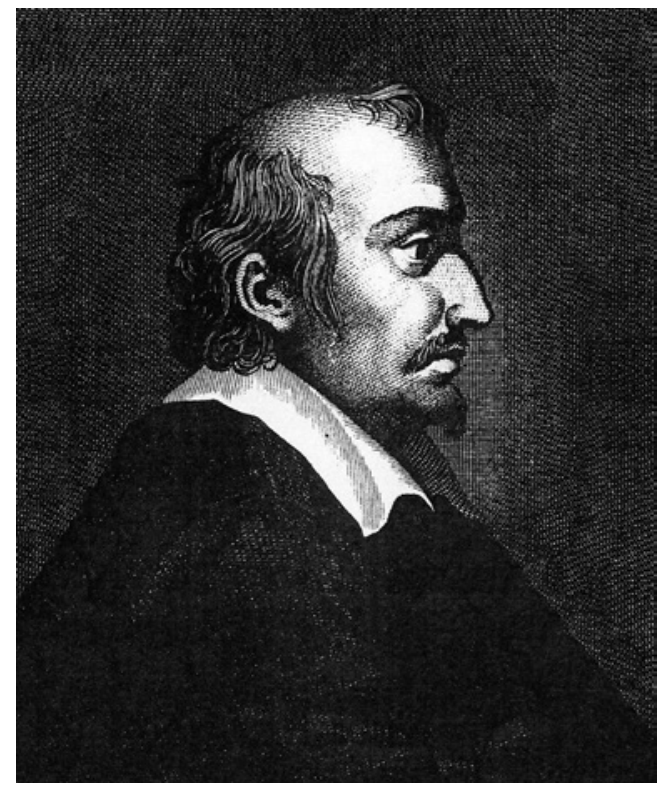

FIGURE 5.86

Jacopo Aconcio, anonymous engraving.

Maximilian's sympathy for Aconcio was related to his interest in the theme of Aconcio's treatise, which espoused a tolerance toward divergent religious opinions and opposed persecution of mistaken or heretical ideas, an attitude which was fully shared by Maximilian until the end of his life. He may also have been interested in Aconcio's theories on scientific method and on historiography. ${ }^{128}$

But Aconcio was a consummate military and civic engineer as well, engaging both in fortification, on which he wrote a treatise, and in hydraulic engineering. He would practice both skills in England, where he spent the last decade of his life. In fact he was explicitly invited by the government of Elizabeth I because of his skill in fortification, which he had learnt during the seven years (ca 1549/50-1556) he had served in the retinue of the Imperial commander, Count Francesco Landriano, in Northern Italy and at the court of Charles $\mathrm{V}$, where he had met and had been instructed by Giovanni Maria Olgiati, the foremost military engineer of the Renaissance. ${ }^{129}$ Within a month of his arrival in London, however, Aconcio petitioned the Queen for a patent - the first in English history-on the production of 'new designs of machines of all sorts that

128 In the literature on Maximilian II no attention was paid to Aconcio until Paula SutterFichtner's biography of the Emperor (Fichtner 2001, pp. 39-40). His possible influence on Maximilian II merits closer investigation; cf. Aconcio/Köhler/Hassinger 1932; Hassinger 1934; Meli 1934; O’Malley 1955; White 1967.

129 White 1967, pp. 440-442. 
use [water] wheels. ${ }^{130} \mathrm{~A}$ few years later, when he had been naturalized, and backed by a group of investors, he obtained a royal privilege to reclaim about two thousand acres of marshland in Kent. It was only in 1564 that Aconcio, to provide a 'second opinion', was added to the committee charged to transform Berwick, which defended the bridge across the Tweed against the Scots, into the foremost fortress in the British Isles. Such engineering skills would have certainly interested Maximilian, who had initiated similar schemes of water management while regent of Spain, as we have seen above.

Aconcio relates that he had decided to study engineering when he began to fear that his heterodox religious opinions would at some time constrain him to flee from Italy, and he would need to have some profession enabling him to survive in exile. He also writes that on arrival in England he had circulated several copies of his own Latin version, Ars muniendorum oppidorum, of his unpublished Italian treatise on the subject. ${ }^{131}$ This treatise, which summarized the principles - or 'universals', as the philosopher Aconcio called them - of fortification, and which was based on first-hand experience obtained within the past decade, would have been of great interest to Maximilian and his father, whose greatest care was the defence of Europe against the Turks. Most of the Italian architects whom Maximilian later persuaded to come to Vienna, such as Sallustio Peruzzi, were in fact military engineers, and employed in Hungary to meet the Turkish challenge. And this interest certainly antedated his accession: In 1563 the Venetian envoy, Giacomo Soranzo, wrote to the Doge that Maximilian

' $<\ldots>$ favours architects and all who bring him new things pertaining to [the arts of] war, or fortifications; and he gives [bounty] to all of them; and I have heard that he has in drawings not only the state of Your Serene Highness [= the Doge], and in particular all the fortresses with many discourses about them, but also the site of this City [= Venice] with annotations and discussions about how one could attack it'.132

130 The patent also applied to 'a new design for building furnaces for dyers and those who make beer, and for other uses, with a great saving of fuel', cited in White 1967, p. 432. The patent was granted only in 1565 .

131 Lord Burleigh owned a copy of the Latin version, Jacobus Acontius de Oppidis Arcibusque muniendis, but to date no manuscripts of either version are known, nor are copies known of a version reputedly printed in Geneva in 1585 . Recently Stephen Johnston of the Oxford Museum of the History of Science has discovered the manuscript of an English translation by Thomas Blundeville, dedicated to the Earl of Bedford, now in the archives of Lord Egremont at Petworth House; cf. Johnston 2005/9, which provides the introduction and a survey of the chapter's headings.

132 Fiedler 1870, p. 217; quoted in Lietzmann 1987, p. 29: ‘<... favorisce gli architetti et tutti quelli che gli portano cose nuove pertinenti à guerra, o fortificationi, et à tutti dona, et 
It is quite probable that Maximilian welcomed Aconcio not just because of his interesting, perhaps congenial philosophical and theological ideas, but also and primarily because he was one of those who had brought the king 'something new pertaining to the arts of war'. If Aconcio, bringing both gifts of peace and war, was welcome, it is not surprising that Strada, mostly bringing gift of peace, was warmly welcomed as well. ${ }^{133}$

\subsubsection{Was this Enough?}

Though there were many master-masons and architects active at Ferdinand's court, some of them quite talented, none of these — not even the one really gifted and intellectual architect among them, Bonifaz Wolmut-appears to have had sufficient authority to guide the Imperial works in a consistent direction. This is borne out by the confusion evident among Ferdinand, the members of his privy council, his Master of Works Hermes Schallautzer, and the various German and Italian architects and/or master-masons involved, in the attempt to design and realize a new, more monumental entry and staircase to the Royal apartment and the castle chapel. According to Renate Holzschuh-Hofer's detailed account, this involved various models sent up and down to Ferdinand, at the time in Prague, various discussions among committees of various size and composition, and at least two trips to Prague of the principal designer, Francesco de Pozzo, in order to discuss the project with the King in person; in the end the project appears to have taken five years to complete. ${ }^{134}$ From the documents and the few remains it is difficult to envisage what may have been Pozzo's and Ferdinand's original intentions. But it is tempting to interpret such remains, four heavily rusticated pilasters at the entrance to the Burgkapelle in the Schweizerhof [Fig. 5.87], not only as the buttresses (the sources speak of 'Contraforten') necessary to support the facade of the chapel, but also as an

ho inteso che hà in disegno non solamente lo stato di Vostra Serenità et particolarmente tutte le sue fortezze con molti discorsi fattigli sopra, ma anco il sito di questa Città con avvertimenti et discorsi come si potesse offendere'. Since it is unlikely that Maximilian was contemplating an assault on Venetian territory, such material must have served as documentation used by himself, his commanders and his military engineers to improve standards of fortification in his own domains.

133 Strada and Aconcio had many things in common: Strada had close contacts with another of Charles v's Italian commanders, the Marquis of Marignano; he had produced a set of designs of exactly the same type of machinery as that for which Aconcio obtained his patent; he had dealings with Pietro Perna, Aconcio's Calvinist publisher in Basel; his orthodoxy was at least suspect; they were both interested in knowledge and its transmission, Aconcio theoretically, Strada more practically. There is no evidence that they knew one another, but it is likely that they knew of one another.

134 Holzschuh-Hofer 2014(a), pp. 104-108, Abb. IV.16 and IV.17. 

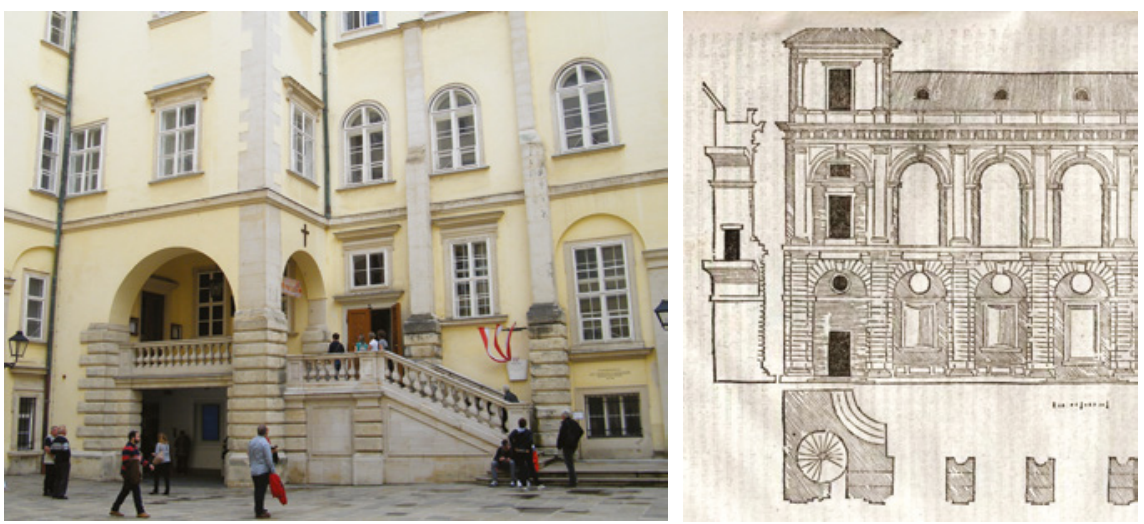

FIGURE 5.87 Rusticated pilasters at the entrance to the Burgkapelle, Vienna, Hofburg.

FIGURE 5.88 Sebastiano Serlio, Fontainebleau, project for the Salle de Bal, 1545-1546, woodcut from the Settimo Libro (Frankfurt 1575).

attempt to construct a rustic socle zone, with blind or open arches, in the manner of Florentine or Roman palace architecture. Perhaps it was even planned to carry an open loggia or a blind arcade on the piano nobile, the level of Ferdinand's apartment: a similar solution had been proposed a few years earlier in Sebastiano Serlio's project for the Salle de Bal in Fontainebleau [Fig. 5.88]. ${ }^{135}$

The first designs and models, as well as the first section, when it began to rise above its foundations, incited voluble resistance both from the local officials and from some of Pozzo colleagues: the piers were considered unfinished and took up too much space of the courtyard; the first floor windows (or rather non-preserved mezzanine windows giving into the vaulting of the ground floor?) were unsightly and the whole thing looked more like a prison than an Imperial residence. The critics' lack of understanding is clear from their abhorrence of the 'unfinished' stone of these piers, that is, of its 'rustic' quality. ${ }^{136}$ This standard element of Italianate classical architecture was quite

135 Serlio 1575, p. 97; Dreger 1914, pp. 103-104; p. 158; Kühnel 1956, p. 258; on the Salle de Bal in Fontainebleau, see Frommel 2002, p. 252, 254-258. Though its design was published only in Strada's edition of the Seventh Book, Frankfurt 1575, it might have been known in Vienna through the contacts between Ferdinand and his sister Eleonora, Francis I's widow.

${ }_{13} 6$ Sigmund de Preda's defence against the critics included the structural function of these piers, which were to support the outside wall of three stories, leaning against the façade of the chapel. The critics held that the windows-'dj fenster am Gwelb so nun im ersten gaden gemacht seinn'- gave the facade 'ein sölche ungestalt unnd nit annders ansehen, als obs ein gefenkhnus sein sol' (Kühnel 1956, pp. 258). Instead of a blind arcade, perhaps a rustic podium including small windows lighting the vaulting of the ground floor was envisaged. In response to the criticism of the 'unfinished', rustic effect of the piers, De 
outside of their frame of reference, though neither outside that of Sigmund de Preda and Schallautzer, who supported Pozzo, nor that of Ferdinand, who had commissioned the designs and approved them even after having considered the criticism. ${ }^{137}$ Though after further consultation he decided for Pozzo's project, the little that remains suggests that in fact it never progressed beyond the initial stage. ${ }^{138}$

This fiasco must have given Ferdinand food for thought: he may have realized that, though he had sufficient competent engineers, his court lacked a competent and sufficiently authoritative designer, preferably proficient in the new Italian or Vitruvian manner. ${ }^{139}$ Though the handling of this casewith its complicated deliberations and its piling-up of alternative designs and models-show that civil architecture was taken quite seriously at court, it had less priority than military engineering, even when intended for Ferdinand himself; doubtless for political and economic reasons. In September 1555, however, Charles v intimated his intention to abdicate, and Ferdinand began organizing the complex process to insure his smooth succession to the Empire. It was clear that this change in status made it more urgent to fill the lacuna. It seems that Strada was the right person, in the right place at the right moment. The manuscript Strada had presented to Ferdinand, during his first documented audience with the King in Regensburg early in 1557, demonstrated his competence as an antiquary; Ferdinand's visit to Strada's studio in Nuremberg almost a year later had made him aware of the treasure of visual documentation this

Preda suggested that this 'defect' that might be obviated: 'Aber die Rauchen stain daran glat zumachen mag woll geschehen' (Dreger 1914, p. 104.), a suggestion which Ferdinand seems to have condoned.

137 In their letter to the King the members of Niederösterreichische Kammer question Schallautzer's and Pozzo's statement that the piers were constructed in accordance with his explicit wishes: 'So haben Sy uns doch bayd, und fünemblich der Schallauczer alweeg zuverstehen geben, Es sey Eur. Khn. Mt. außtrukhlicher Bevelh', quoted in Dreger 1914, pp. 103-104. Dreger already suspected that the unusual Renaissance forms of these piers had contributed to the misgivings of the Vienna masons and architects, because it did not fit their Late-Gothic artistic perception ('Kunstempfinden'). Oddly enough, Bonifaz Wolmut was among the critics, though in his case this was probably due to his doubts as to the propriety of these forms in this particular place, rather than to any lack of artistic perception of Renaissance architecture.

138 There appears little doubt that these piers are relics of the 1549-1551 restructuring (cf. Dreger 1914, p. 158). The architecture suggests that it may have been intended to restructure in this manner at least one of the courtyard facades (that of the south-west-façade, housing the royal apartment?); if so, any traces of this would have disappeared when a new, even more monumental staircase hall was constructed in front of this façade. But in view of the little that remains, this seems unlikely, and even if planned, it may never have bene executed because of the huge expense it would have involved.

139 Possibly the appointment of Hans Tirol as an architect in 1551 can be seen as a first attempt to fill this lacuna? 
included, in particular his collection of measured drawings of both ancient Roman architectural remains, and up-to-date architectural projects in Rome and elsewhere in Italy. He must have realised that Strada's presence at court would make all this material available at no or very little cost to himself: doubtless this consideration heavily influenced his eventual decision. ${ }^{140}$

By the time of his visit to Strada's studio, Ferdinand would have heard informal reports on Strada's competence from Hans Jakob Fugger and from some of his other patrons and associates (such as Antonio Agustín, at the time present at court as Papal Nuncio, and Cardinal Otto Truchsess von Waldburg, PrinceBishop of Augsburg, who accompanied Ferdinand on his visit). These appear to have been positive, if Ferdinand decided to accept Strada's formal offer of his services. As we have seen, the few documented assignments he was given in his first years in Vienna were all in the field of architecture, and when Strada was finally formally appointed, it was as an architect, rather than as an antiquary. So it was his competence as such, that motivated Ferdinand's decision.

\subsection{Strada's Competence as an Architect}

\subsubsection{Practical Experience}

To understand Jacopo Strada's role in the architectural establishment at court, it is necessary to consider for what reasons he was held capable for that function, even though he himself had taken pains to present himself as a learned antiquary and had applied for an appointment as such, rather than as an architect. The little we know or can infer about Strada's earlier career suggests that he probably had some practical experience as an architect, though we do not know exactly what this may have entailed. The hypothesis that he was in some way involved in the construction of the Italienische Bau of the Stadtresidenz in Landshut remains speculation; that he made the designs for decorative elements of the Fuggerhaus at Donauwörth remains an attribution. ${ }^{141}$

On the other hand we do know that Strada was capable of preparing architectural designs, since he had made measured drawings of the remnants of antique monuments in Rome: it is likely that he had been taught at least the

140 Cf. above, Ch. 4.1-4.2. Strada himself referred in guarded terms to the advantage of his wealth and collection when pressing Ferdinand's first chamberlain, Martin de Guzmán, for an answer: 'sempre sarò efitionatissimo a la Casa d'Austria, et spenderò la robba et l'honore per Lei dove potrò' (Doc. 1558-02-21); a passage in his letter to Ferdinand himself might be stretched to include a similar intention: 'Hora se la Maestà Vostra li piace di acetarmi nel numero de li suoi servitor, del canto mio farò ogni debito di farmi honore' (Doc. 1558-02-12).

141 Cf. above, Chs. 2.3 and 3.4. 
rudiments of this art already as a youngster in Giulio Romano's studio, in his native Mantua. His reconstructions of Roman monuments as illustrated on the reverses of ancient Imperial coins in his numismatic corpus demonstrate both his competence as an architectural draughtsman and his profound theoretical knowledge of classical architecture, doubtless derived at least in part from Giulio's precept [Fig. 5.89]. The only existent architectural designs for a contemporary building by his hand that have been identified to date, those for the Munich Antiquarium of 1568 , confirm that by that date he was a competent architectural designer [below, Figs. 8.15, 8.17, 8.20]. ${ }^{142}$ And he would not have

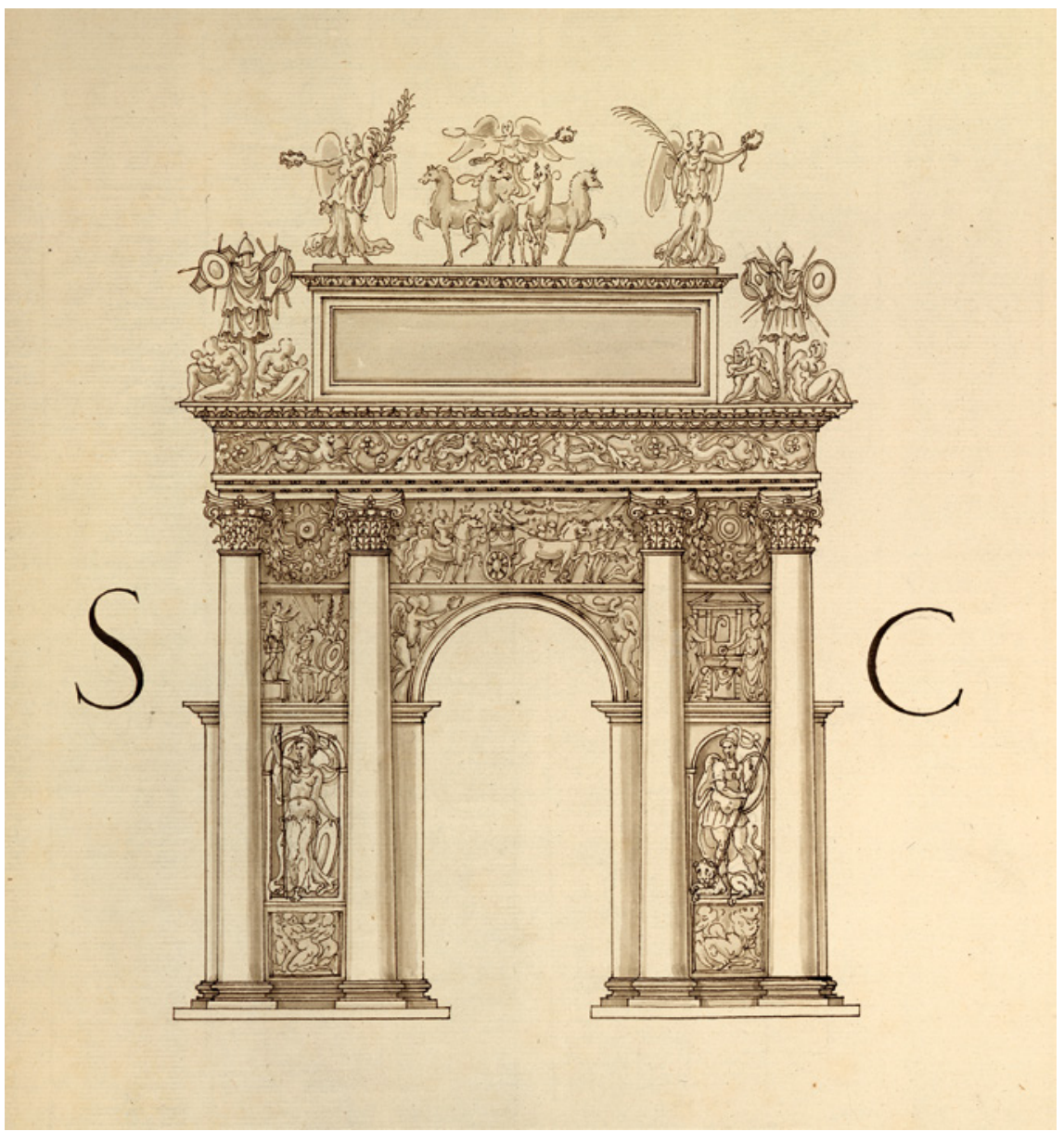

FIGURE 5.89 Jacopo Strada and workshop, triumphal arch: reconstruction based on the reverse of a Roman coin; drawing in pen, ink and wash, from Strada's Magnum ac novum opus, vol. 11, fol. 27r; Gotha, Forschungsbibliothek.

142 Below, Ch. 8. 
been asked to provide these if he had not had at least some previous experience in the field. Certainly Hans Jakob Fugger, who was responsible for the coordination of the Antiquarium project, at this same time complimented Strada on the success he had had with his design for Emperor Maximilian II's Lustschloß Neugebäude. It is surely significant that he added that he had not been surprised: 'non dubito punto di fatti Vostri, havendoVi conosciuto tanti anni', 'having known you for so many years'; and he added that the Emperor was lucky to have found someone who could well design the planned building. ${ }^{143}$

\subsubsection{Theoretical Knowledge and the Musaeum}

Moreover, even had he been poor in practical experience of architecture, Strada was well versed in the theory of contemporary architectural design, as we have seen. After growing up in Mantua while Giulio realized some of the Gonzaga's grandest splendours, including the Palazzo del Te, in the 153 os and later in the 1550 s he spent some time in Rome, where he not only could admire the commissions realized for the Farnese Pope, Paul III, and his relatives, but also could participate in the learned antiquarian researches done under the aegis of Cardinal Marcello Cervini, by, for instance, architects such as Vignola, Pirro Ligorio and Philibert de l'Orme. ${ }^{144}$ Certainly he developed a passionate interest in architecture, which expressed itself in projects to measure exemplary modern buildings as well as ancient remnants, or at least to acquire the results of such projects undertaken by others. It is therefore not surprising that the large collection of graphic material he brought together included a great quantity of architectural drawings. Perhaps the most important component of this was Sebastiano Serlio's collection of manuscripts and drawings, which he could acquire in Lyon, shortly before the death of this influential architectural theorist. Serlio's collection included manuscript versions of the unpublished books of his architectural treatise, which he had reedited at Strada's express commission. Strada planned to publish all of these, though he would succeed in printing only the Settimo Libro, which was issued in Frankfurt in 1575. The preparing of such material for the press again presupposes some considerable architectural know-how. ${ }^{145}$

143 Doc. 1568-11-13: 'I have never doubted what you could do, having known you for so many years'. The project for the Neugebäude is discussed below, Ch. 9 .

144 Abovr, Vh. 3.7. The informal 'accademia di nobilissimi gentiluomini e signori che attendevano alla lezione di Vitruvio' (Vasari), is discussed in Daly Davis 1989 and Daly Davis 1994, esp. pp.11-18; Kulawik 2002, pp. 30-31 and 119-127.

145 In his preface Strada that it won't be difficult for him to prepare Serlio's as yet unpublished manuscripts for the press, 'per la pratica che ho nelle cose sue, et nell'ordine ch'egli tiene'; a formulation which suggests that Strada himself intended to finish those elements that Serlio had not been able to complete (Serlio 1575). On Strada's acquisition of Serlio's material, and his subsequent edition of the Seventh Book, see Jansen 1989. 
Apart from Serlio's material, Strada acquired large quantities of drawings from the estates of Perino del Vaga and Giulio Romano, which included many architectural designs both by Giulio himself and by other artists, among whom Raphael — the master in whose studio Giulio and Perino had received their training - had pride of place. These acquisitions were complemented by specially commissioned measured drawings of both antique relics and contemporary architectural and decorative projects, such as Raphael's Loggia in the Vatican. ${ }^{146}$

Given his training in Giulio Romano's milieu, it is not surprising Strada was particularly interested in the decorative aspects of architecture: for Raphael and Giulio at least, these seem to have been inseparable. It is significant that Strada was partly trained as a goldsmith, that is as a decorative artist. The craft of the goldsmith could be exercised in conjunction with the design or modelling of architectural decoration: Niccolò da Milano, one of the stuccoists working in the Palazzo del Te, was also a well-known goldsmith. Strada's association with Wenzel Jamnitzer, and his own designs, particularly those for the frontispieces of his manuscripts, show that he certainly was capable to design ornament, including ornament of an architectural nature.

\subsection{3 'Commisarius Bellicus': Was Strada Employed as a Military Architect?}

Besides civic architecture and decoration, Strada would have had at least some interest in the art of warfare and in fortification and military engineering, an essential component of architecture and in the sixteenth century a particular specialty of Italian architects and mathematicians. He must have found material relating to this among Serlio's manuscripts, who also owned drawings he had been left by Peruzzi, which in its turn may have included material deriving from Francesco di Giorgio Martini. Strada's knowledge of technical inventions, which dated back at least to his contacts with the Marquis of Marignano, largely depended on such sources, which he and his son and grandson exploited in manuscripts and publications prepared in their studio. ${ }^{147}$ His collection also included some documentation relating to (near) contemporary warfare. Among this were a detailed depiction of the camp inhabited by Suleiman the Magnificent during his siege of Vienna in 1529, and several other materials relating to the encampment and the battle order of the Turkish foe, which Strada

\footnotetext{
146 Cf. below, Ch.13.8.

147 The designs included in the printed version published by Ottavio II Strada in 1617-1618 (Strada, Jacopo 1617-1618) largely derive from inventions by Francesco di Giorgio Martini; cf. RETI 1963; Marchis / Dolza 2002; Dolza 2003.
} 
had obtained from various sources; but also the manuscript of a military treatise by the French general Guillaume du Bellay, and a set of drawings of medieval weapons, armour, and war machinery.

But even such relatively contemporary material appears to have been collected for its antiquarian and documentary value, rather than for immediate practical application. This is certainly the case with the comparable documentation on the battle order of the ancient Romans - which in fact was an integral reproduction of Giulio Romano's frieze in the Camera degli Stucchi of the Palazzo del Te-and of their manner of encamping an army as reconstructed by Sebastiano Serlio on the basis of Polybius' Castrametatio. It is significant that contemporary fortification is conspicuously lacking among the materials Strada singled out for publication, though his Musaeum doubtless included at least printed versions of such material. ${ }^{148}$

After his prolonged stay in France and in Rome, during which he had made these acquisitions, Strada had returned to Nuremberg. As we have seen, the new Emperor, Ferdinand I, had received Strada in audience and had visited his studio in person, so he was aware of the latter's first-hand experience of the most recent developments in the arts. His decision to take Strada into his service must have been motivated at least as much by his architectural and artistic know-how as by his antiquarian expertise. Though Strada had presented himself as an antiquary and was initially consulted in this latter capacity, when he obtained a formal appointment at court it was in his capacity as an architect.

One of Ferdinand principal cares was the defence of his territories against the Turks, and most of the architects and masons in his service were primarily employed in fortification in Hungary. But in contrast with most other Imperial architects of the time, there is no direct evidence that Strada was ever actively employed in fortifications or other military commissions. All the same, in view of the continuing Turkish presence in Hungary, it cannot be excluded that Strada occasionally was recruited for the war effort.

The invention of gunpowder and the development of ever more effective artillery had disqualified traditional warfare on the medieval pattern, especially where siege warfare was concerned. For the battlefield, however, and perhaps for the logistics of campaigns in the field, the classical art of warfare as expounded in Polybius, Vegetius and Caesar was not yet redundant, and Strada may well have been asked to help conciliate ancient precept and modern practice: of the latter he must have been aware thanks to his earlier connection with as famous a general as the Marquis of Marignano and his circle.

148 All this material discussed in greater detail below, Ch. 13. 
The material he collected on the subject shows that he was interested in it, or at least was aware of its importance. As in other sciences, the practitioners of strategy of the Renaissance-one thinks of Maximilian II's intellectual, humanist-trained commander-in-chief, Lazarus von Schwendi-will have been interested in practice and precepts of their antique predecessors, certainly of those of great warriors such as Alexander, Caesar and Trajan. ${ }^{149}$ Strada was in a position to hand them the materials and comment on these, and it is as such, as a learned counsellor, that he may possibly have played a minor role in the military deliberations at court. In addition he may have been expected to use his contacts in the learned world and the book trade to obtain information and documentation that might be useful in developing concrete strategies.

Finally it is possible that his workshop was employed in preparing and/or copying maps, sketches and designs necessary for the war effort. Thus the engraver Martino Rota, who is documented working for Strada and engraved a portrait of his second son Ottavio, also specialized in antiquities and in maps. A sketched map of the situation of the stronghold Szatmár (now Satu Mare in Romania) among Strada's papers in the Strahov codex in Prague [Fig. 5.9o], is a possible relic of some such involvement, probably on the occasion of its siege by the Ottoman army under Ibrahim Pasha in 1562, or later, when it had been reconquered, and Lazarus von Schwendi ordered the architect Ottavio Baldigara to rebuild the citadel according to modern principles of fortification. ${ }^{150}$

Even if Strada would have been involved in this case, the dearth of sources indicates that such activity would at most have been a side-line for him, though it might help explain the inscription on Strada's portrait [Fig. 5.91]. This reads JACOBVS DE STRADA. / CIVIS ROMANUS CAESS: / ANTIQVARIVS ET COM: / BELIC: AN: AETAT: LI: etC: / M.D. LXVI. Though ancient, this inscription is doubtful, and was probably renewed or adapted sometime after his death. ${ }^{151}$ The only possible solution of the abbreviation COM: BELIC: is 'Commissarius Bellicus', which one could translate in German as 'Kriegscommissar'. This was a rank or function that in fact did exist in the Imperial army at the time, but there is no indication at all that Strada ever was a soldier, let

149 Strada's 1575 edition of Caesar was supplemented by illustrations of the pitched battles and sieges described, cf. below, Ch. 14.5.3.

150 Vienna, Prague, Library of the Strahov Monastery, Prague, cod. DL III 3, fol. 106; on Satu Mare, cf. http://en.wikipedia.org/wiki/Satu_Mare and http://www.satu-mare.ro/despre/ istorie.html.de.

151 Discussed in Crowe/Cavalcaselle 1877-1878, p. 658, n. 12; Zimmermann 1901, pp. 830-835; Wethey 1969-1975, II, cat. 100, p. 141; Mucchi 1977; Ferino-Pagden 2008, cat. nr. 1.13. 


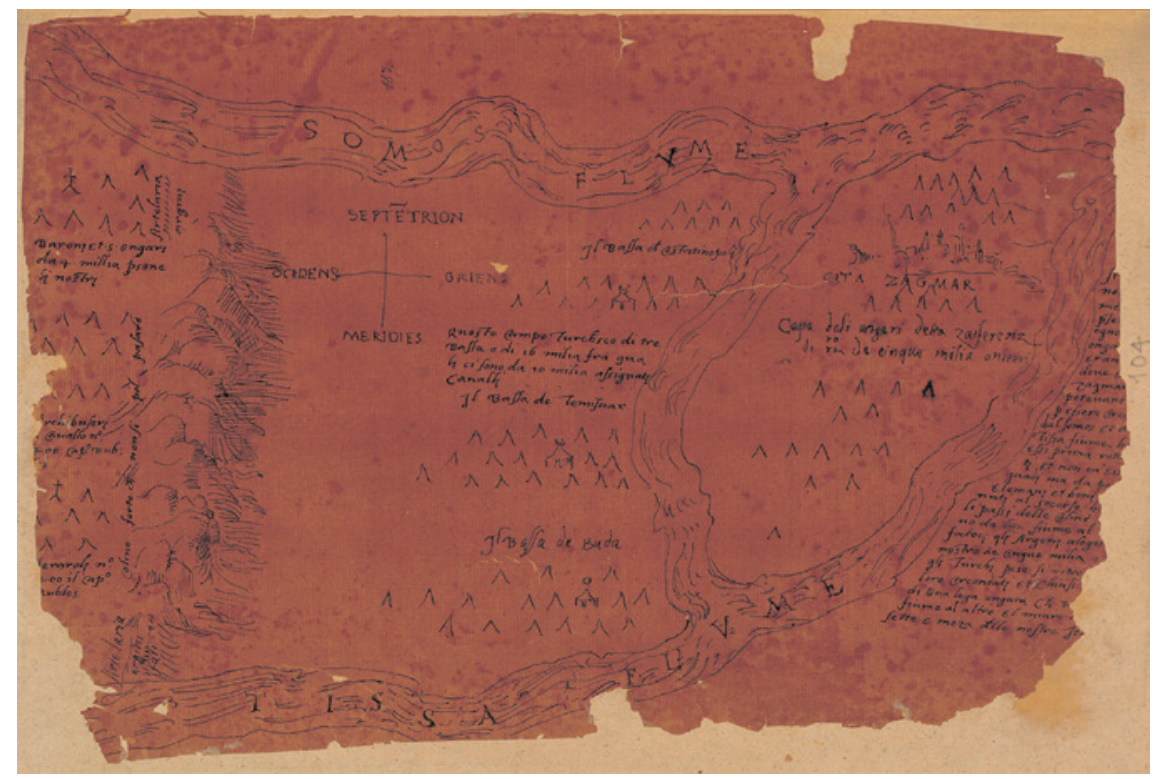

FIGURE 5.90 Anonymous sketch of a battle in the vicinity of Szatmár (Satu Mare) in Transylvania, inserted in the Strahov Codex.

alone that he would have been a high-ranking officer. ${ }^{152}$ The few hard facts available suggest that as an architect he was primarily involved in the design of the Imperial residences and their decoration, as is reasonable to expect in view of his background and his earlier experience.

This is corroborated by the fact that Strada first was appointed as 'ain paumaister bey unnseren gebewen alhier', that is in Vienna. The need for better accommodation of the court had been felt earlier and had already led to some additions and adaptations of the Habsburg residence in Vienna, the Hofburg. But it was not just extra space that was needed, but also a more representative space, which could at least in some measure compete with the pomp displayed by other princely courts. This need became even more urgent at Ferdinand's accession to the Empire. The process by which the court painter Pietro Ferrabosco was transformed into a very professional architect may serve as an

$15^{2}$ The suggestion that the word 'BELIC': may have been mistakenly restored from 'AULIC':, first suggested by Crowe and Cavalcaselle, but denied by Zimmermann, may possibly be the right one, as long as it would refer to a purely honorific title 'Hofrat'; Sambucus, for instance, also held this title. Possibly that part of the inscription was added by Strada's grandson Ottavio (II), who had never known his grandfather and may not have been informed about his exact position at court. 


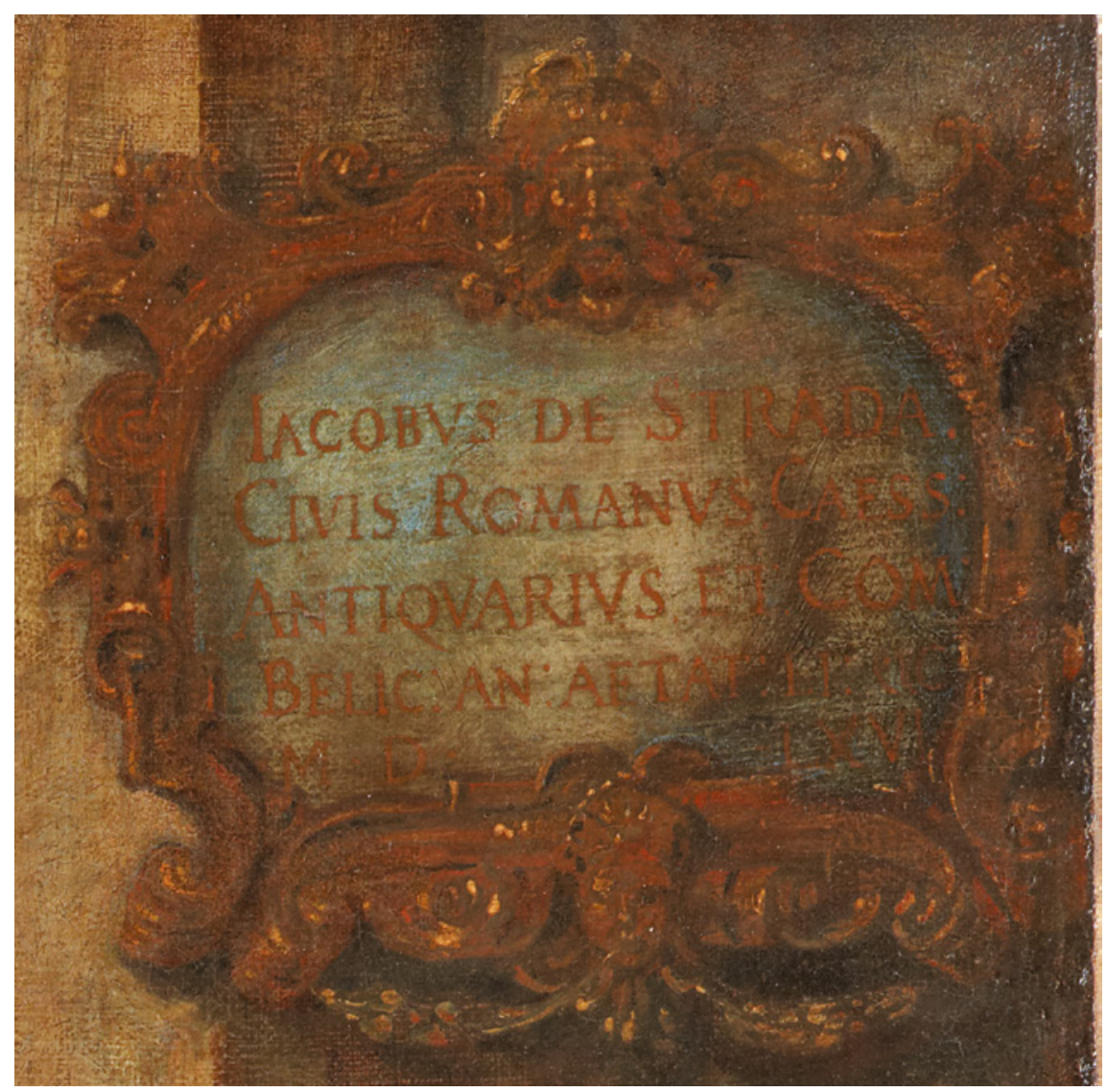

FIGURE 5.91 The inscription on Titian's portrait of Jacopo Strada.

indication of the need felt for more up-to-date, more cosmopolitan design that would be better suited to serve the needs of Imperial Representatio. So Strada arrived at court at a time when up-to-date architectural know-how must have been particularly welcome, and would have been employed primarily in that field. Moreover, Strada's own taste and style - a very reduced, simple and rational type of classicist design directly derived from the more sober designs of the Roman High Renaissance, in particular form the works by Raphael and Strada's own teacher, Giulio Romano-corresponded closely to Ferdinand's preference for the 'subtle, unassuming, noble elegance', as described by Renate Holzschuh-Hofer. 